$$
\therefore
$$
OCT 181993
WHC-EP-0688
OSTI

\title{
Fixation of Soil Surface Contamination Using Natural Polysaccharides
}

Prepared for the U.S. Department of Energy Office of Environmental Restoration and Waste Management

\section{(QP) Westinghouse Hanford Company Richland, Washington}

Hantord Operations and Engineering Contractor for the

U.S. Department of Energy under Contract DE ACO6 87RL10930 


\section{LEGAL DISCLAIMER}

This report was prepared as an account of work sponsored by an agency of the United Slates Government. Neither the United Slates Government nor any agency thereol, nor any of their employees, nor any of their contractors, subcontractors or their employees, makes any warranty, express or implied, or assumes any legal liability or responsibility for the accuracy, completeness, or any third party's use or the results of such use of any information, apparatus, producl, or process disclosed, or represents that its use would not intringe privately owned rights. Reference herein to any specific commercial product, process, or service by trade name, trademark, manulacturer, or otherwise, does not necessarily constifute or imply its endorsement, recommendation, or lave-ing by the United States Government or any agency thereof or its contractors or subcontractors. The views and opinions of authors expressed herein do not necessarily slate or reflect those of the United States Government or any agency thereof.

This report has been reproduced from the best available copy Available in paper copy and microlicho.

Avallable to the U.S. Department of Energy

and its contractors from

Office of Scientific and Technical information

P.O. Box 62

Oak Ridge, TN 37831

(615) 576.8401

Available to the public from the U.S. Department of Commerce National Technical Intormation Service

5285 Port Royai Hoad

Springfield, VA 22161

(703) 487.4650

Printed in the United States of America 
WHC-EP-0688

\title{
Fixation of Soil Surface Contamination Using Natural Polysaccharides
}

\author{
M. R. Sackschewsky
}

Date Published

September 1993

Prepared for the U.S. Department of Energy Office of Environmental Restoration and Waste Management

\section{(2) Westinghouse \\ P.O. Box 1970 \\ Hanford Compamy Richland, Washington 99352}

Hanford Operations and Engineering Contractor for the

U.S. Department of Energy under Contract DE-AC06-87RL10930

Approved for Public Release 


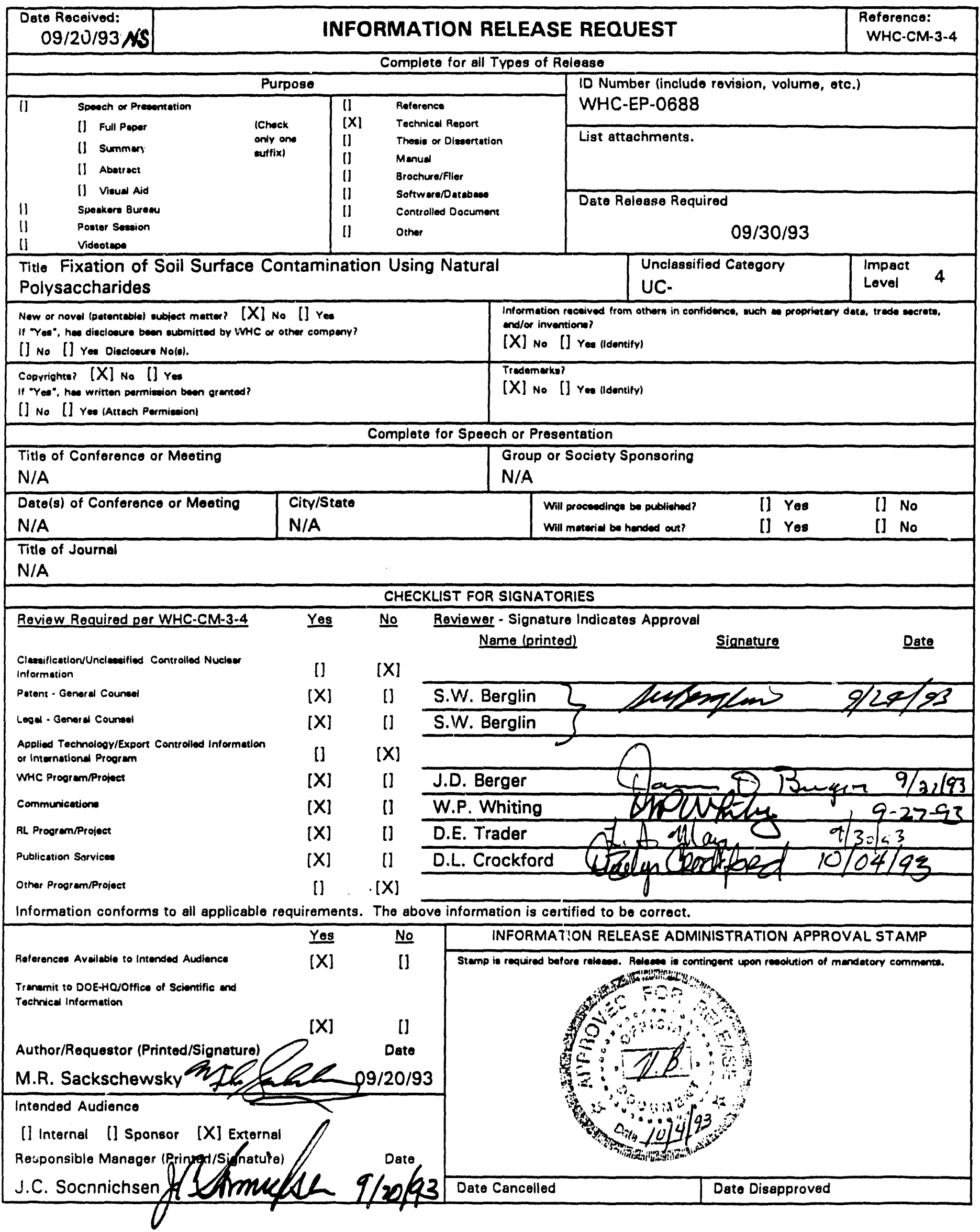


WHC-EP-0688

\section{ACKNOWLEDGEMENTS}

This work was sponsored by the U.S. Department of Energy Office of Technology Development and was funded through the Buried Waste Integrated Demonstration.

Valuable assistance was contributed by many individuals. Michael $W$. Ligotke performed the wind-tunnel evaluations. R. Michael Shailer and Michael A. Baechler performed the laboratory analyses. Assistance in the large-scale demonstrations at INEL was provided by David N. Thompson and Vaughn E. Wixom. Roy G. Bauer provided many useful comments and suggestions. Christopher J. Kemp provided help during all phases of this study. 
WHC-EP-0688

\section{EXECUTIVE SUMMARY}

Natural polysaccharides were evaluated as alternatives to commercially available dust-control agents for application in buried-waste and contaminated-soil remediation situations. Materials were identified and evaluated with specific criteria in mind: the materials must be environmentally benign and must not introduce any additional hazardous materials; they must be effective for at least 2 or 3 days, but they do not necessarily have to be effective for more than 2 to 3 weeks; they should be relatively resistant to light traffic; they must not interfere with subsequent soil treatment techniques, especially soil washing; and they must be relatively inexpensive.

Two products, a pregelled potato starch and a mixture of carbohydrates derived from sugar beets, were selected for evaluation. Testing included smal1- and large-scale field demonstrations, laboratory physical property analyses, and wind-tunnel evaluations. Field demonstrations were conducted to evaluate the effectiveness of the products in a remediation-type setting and to identify specific situations in which the products were most useful. Laboratory analyses were performed to evaluate the ease with which the products could be removed from various types of soil, indicating the relative effect that the products might have on a soil washing system. Wind-tunnel evaluations allowed for quantitative evaluations of the degree of wind erosion protection provided by the products.

The laboratory analyses indicated that both the potato starch and the sugar beet products were readily removed from sandy soil. The starch also was 
easily removed from a silty soil from the Idaho National Engineering Laboratory (INEL). The sugar beet solution was more difficult to remove from the silty INEL soil, indicating that it might induce a slight reduction in soil-washing efficiency of this soil type. The potato starch probably would have no effect on a soil-washing system. Neither product was easy to remove from a Hanford Site fine silt soil.

Wind-tunnel evaluations indicated the potato starch was most useful for steep, dig-face stabilization and was preferable in this application to a dust-suppressant foam, which also was tested for that purpose. The sugar beet product was most useful for general dust control around an excavation site, especially when subsequent soil treatments are planned. If general, long-term dust control is required and subsequent soil treatment is not planned, calcium lignosulfonate is preferable. This preference is based on both cost and performance.

Each of the products were shown to have a strong potential for use as dust-control agents and soil fixatives in excavation and remediation environments. Each had particular situation-specific advantages and had different end uses.

This work was performed as a portion of the Buried Waste Integrated Demonstration, sponsored by the U.S. Department of Energy Office of Technology Development under TTP\# RL432002. 
WHC-EP-0688

\section{CONTENTS}

1.0 INTRODUCTION . . . . . . . . . . . . . . . . . . . 1

1.1 CURRENT STATE OF TECHNOLOGY . . . . . . . . . . . . . 1

1.2 NATURAL POLYSACCHARIDES AS SOIL FIXATIVES . . . . . . . . . 3

1.3 PRODUCT EVALUATION PROCESS ................. 5

2.0 FIELD TRIALS AND DEMONSTRATIONS . . . . . . . . . . . . . 7

2.1 PRODUCT SOLUBILITY TESTS AND SOLUTION PREPARATION . . . . . . . 7

2.2 SMALL-SCALE FIELD TESTS . . . . . . . . . . . . . . . . 7

2.3 LARGE-SCALE FIELD DEMONSTRATIONS . . . . . . . . . . . . . . . 8

2.3.1 Comparison of XDCA with Calcium Lignosulfonate. . . . . 9

2.3.2 Comparison of Potato Starch and Dust-Suppression Foam . 10

3.0 WIND TUNNEL EVALUATIONS ................. 13

3.1 EVALUATION METHODS . . . . . . . . . . . . . . . 13

3.2 EVALUATIONS OF SURFACE CRUSTS ON INEL SOIL . . . . . . . . . . . . . 14

3.3 EVALUATIONS OF SURFACE CRUSTS ON HANFORD SITE SANDY SOIL $\cdot$. $^{*} \cdot 15$

3.4 CONCLUSIONS ..................... 15

4.0 LABORATORY ANALYSES . . . . . . . . . . . . . . . . 17

4.1 SAMPLE PREPARATION AND ANALYSIS . . . . . . . . . . . . 17

4.2 INEL COLD-TEST PIT SOIL . . . . . . . . . . . . . . 17

4.3 HANFORD SITE SANDY SOIL ................... 18

4.4 HANFORD SITE SILTY SOIL ................... 18

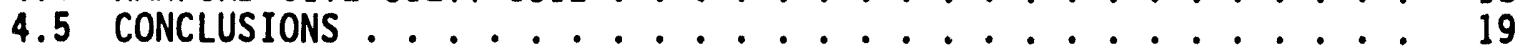

5.0 SUMMARY AND CONCLUSIONS ..................... 24

5.1 EVALUATION OF POTATO STARCH . . . . . . . . . . . . . 24

5.2 EVALUATION OF XDCA ................... 25

5.3 TECHNOLOGY TRANSFER ..................... 25

6.0 REFERENCES . . . . . . . . . . . . . . . . . . 28 APPENDIX

A WIND TINNEL TESTS OF BIODEGRADABLE FUGITIVE DUST SUPPRESSANTS

BEING CONSIDERED TO REDUCE SOIL EROSION BY WIND AT

RADIOACTIVE WASTE CONSTRUCTION SITES 
WHC-EP-0688

\section{LIST OF TABLES}

4-1. INEL Silty Soil - Percent Passing, Dry and Wet Sieve Procedures . . 20

4-2. Met Station (Hanford Site) Sandy Soil - Percent Passing, Dry and

4-3. McGee Ranch (Hanford Site) silty Soij - Percent Passing, Wet and

Dry Sieve Procedures . . . . . . . . . . . . . 22 
WHC-EP-0688

\subsection{INTRODUCTION}

A large proportion of the radioactive and hazardous waste at U.S. Department of Energy (DOE) facilities has been either stored or disposed of within the soil medium. This includes solid-waste burial grounds, cribs for the disposal of liquid effluents, and unintentional release sites. Even waste material in underground storage tanks can be considered to be in the soil medium. Any attempt to retrieve or treat these waste materials may generate dust and may result in wind-borne contaminant spread. This is especially true for activities that require extensive earth-moving activities, such as the retrieval of buried solid waste, or in the excavation and treatment of contaminated soil. The potential for contaminated-dust generation is present at all of the DOE facilities, but is especially acute at arid sites such as the Hanford Site, Idaho National Engineering Laboratory (INEL), Rocky Flats, The Nevada Test Site, and Los Alamos National Laboratory.

Dust control during large-scale earth-moving activities is required both to comply with nuisance dust-emission control requirements of the Clean Air Act and to prevent the inadvertent spread of radioactive or hazardous materials that could be adhering to the dust particles. Methods of controlling fugitive dust and contaminant spread may include the engineering of equipment to minimize dust generation, but more often the methods involve some active measure, such as the application of dust suppression substances. The selection of specific materials for dust control at a particular excavation site depends on the duration of protection required, the amount of disturbance the treated surface will receive, the soil type, and the predicted subsequent treatment of the soil.

The goal of the work described in this report is to identify products that can effectively control dusi generation in situations that meet the following assumptions.

- The product must be environmentally benign and must not introduce any additional hazardous materials to the remediation environment.

- The product must be functional for at least 2 to 3 days but probably not for more than 2 weeks.

- The product must be able to withstand light foot and vehicular traffic, which may be encountered.

- The soll will subsequently receive some form of remediation treatment, such as soil washing.

With these assumptions in mind, an overview of available materials is provided in the following section, followed by a discussion of natural polysaccharide products selected for further field and laboratory evaluations.

\subsection{CURRENT STATE OF TECHNOLOGY}

The simplest and perhaps most commonly used dust-suppression agent is plain water. This is common in many industrial and construction settings, and 
functions well in high-traffic areas if the soil surface is kept moist. However, the addition of too much water may be detrimental because it can create muddy conditions that can interfere with efficient vehicle movement; this is especially problematic in soils with a high clay content. At radioactive or hazardous waste sites, the addition of too much water may increase the amount of infiltration and could induce leaching of the contaminants to the ground water. Surfactants can be added to the water spray to increase the wetability and to increase the dust-control efficiency of the spray. Water sprays, with or without surfactants, are useful during active excavation work, but the effectiveness is relatively short lived, especially in hot, arid environments where soil surfaces can dry out in less than 1 hour.

A vast array of chemical dust-suppression materials are commercially available, and many of these are extremely useful for specific applications. The available materials fall into several general categories: salts, petroleum byproducts, wood byproducts, synthetic polymers, and foams. Salts, such as potassium chloride, are often used to control nuisance dust on gravel or dirt roads. Salts function by absorbing water from the atmosphere, thus maintaining a higher moisture content in the surface soil. The usefuiness of salts is not well proven in contaminated environments, and the salts conceivably could alter the chemical make-up of the soil, which may effect chemically based soil treatments.

Petroleum byproducts function well for long-term dust control in high-traffic areas. This is a broad category that ranges from oil sprays to asphalt, which could be considered to be a permanent dust-suppression method. There are several major disadvantages to using these products in a remediation setting. First, these products may be difficult, if not impossible, to remove from soil once applied. If a soil-washing system is used, all of the soil treated with the petroleum product would have to be disposed of as waste, thus decreasing the waste-reduction efficiency of the treatment process. Second, some of these products themselves could be classified as hazardous materials. Third, the products could interfere with site monitoring efforts, espectally for volatile organic compounds.

Wood processing byproducts fall into two distinct varieties: tall-0il pitch, which is essentially a modified tree sap; and lignosulfonate, a modified form of a natural polysaccharide, lignin, which bonds cellulose fibers together within the wood. Lignosulfonates are produced as a byproduct of pulp manufacturing. Both of these varieties of wood byproducts are commonly used and are useful. Each al so has been used in hazardous or radiological environments. Tall-oil pitch has been applied over several tank farms at the Hanford Site, with good results, and has been evaluated for use at INEL (Winberg et al. 1990). The primary reason it was not selected for further use at INEL was the long cure time required. This could be a distinct disadvantage at an active waste site, because the uncured crust material could adhere to equipment and tires, both compromising the effectiveness of dust control and potentially spreading contaminated materials. An additional disadvantage is the difficulty in removing the material for the soil within a soil-washing system. These products are probably best reserved for 1ong-term dust suppression (e.g., many months). 
WHC-EP-0688

Lignosulfonate, especially the calcium sait, is also an effective dustcontrol material, and has great promise in waste retrieval and remediation settings. Calcium lignosulfonate also was evaluated at INEL (Winberg and Wixom 1992) and ultimately was selected as the primary dust suppression agent to be applied with the INEL Contamination Control Unit (CCU). The primary disadvantage of calcium lignosulfonate is that it may be difficult to remove from the soil, although not as difficult as a tall-oil pitch. Also, calcium lignosulfonate is shipped in a thick concentrate that was difficult to pump from the barrel to the application system.

Synthetic polymers, such as polyvinyl acetate, form distinct, hard crusts on the soil surface, which are often impermeable to water. If applied at high rates, polyvinyl acetate can form a surface capable of withstanding a considerable amount of vehicular traffic. These properties make synthetic polymers useful in many industrial settings. Again, the principal disadvantage in relation to waste remediation activities is that these materials may be impossible to remove from the soil. An additional

disadvantage is that although most are fairly common substances, such as white glue, some may be classified as hazardous under certain conditions, thus requiring special handling techniques and producing the potential for the creation of mixed (hazardous and radioactive) waste.

Foams used for dust suppression are essentially the same materials used for sprayable insulation or for fire-fighting foams. Although specialized equipment is normally required, the foams can be applied quickly, and they dry within minutes to form a blanket-like layer on the soil surface. One disadvantage is that the dried foam does not easily dissolve, although it can be readily pulled off the soil surface, thus increasing waste generation. However, the most serious disadvantage is the presence of toluene di isocyanates in the raw materials. Even though these instantly react with the air and water to form innocuous products at the time of application, the presence of this substance in the raw materials may require a high degree of personal protective equipment and respiratory protection for the workers applying the foam. This would be especially true within a hazardous waste or radiological zone, or in confined-space conditions.

\subsection{NATURAL POLYSACCHARIDES AS SOIL FIXATIVES}

The work described in this report was conducted to evaluate natural polysaccharides as an alternative to currently available dust-control products. This work was designed specifically to identify products that could be used in an active waste-retrieval situation and to identify products that meet the following criteria.

- The product must be environmentally benign and must not introduce any additional hazardous materials to the remediation environment.

- The product must be functional for at least 2 to 3 days but probably not for more than 2 weeks.

- The product must be able to withstand light foot and vehicular traffic, which may be encountered. 
- The product must be easily removed from the soil so that it does not interfere with a soil-washing system.

- The product should be relatively inexpensive.

The duration of desired effectiveness is set between about 2 - 20 days because in an active excavation or retrieval operation, applied materials would need to function for over-night or over-weekend dust control and probably would be removed after the excavation work recommences.

Polysaccharide materials offer considerable promise in meeting all of the proposed criteria for active waste site dust suppression. These materials are naturally sticky; therefore, they are capable of binding soil particles together in a relatively strong matrix and, being byproducts of food processing (or food products themselves), the polysaccharide materials are unlikely to be considered hazardous. Additionally, being natural, organic materials, they should be relatively short lived in the environment, and they should be easily dissolved in a soil-washing system. Therefore, polysaccharide materials would not interfere with the particle separation efficiency or create additional waste volumes.

Two different products were selected for intensive evaluations and field demonstrations. These products are a pregelled, granular potato starch, and a solution of simple and complex polysaccharides derived from sugar beet processing. Each of these products offers distinct advantages over other commercialiy available materials, and each shows promise for different types of field applications.

The potato starch product is an unmodified food starch that is pregelled during the manufacturing process. The material was obtained from PenWest Foods, Inc., and is normally sold as a food product used to thicken gravies and puddings. The pregelled starch product will dissolve directly cold water to form a viscous, clear, sprayable solution; raw starch will not. Without the pregelling process, a starch solution must be either heated or chemically treated to hydrolyze the starch. Otherwise, the starch will not fully dissolve, and it will quickly precipitate out of the solution.

Teter (1987 and 1988) and Biermann et al. (1991) evaluated wheat flour as a soil fixative and found that it was an effective material for the control of dust and contaminant spread. However, they had to hydrolyze the flour with sodium hydroxide and then neutralize the solution with sulfuric acid to obtain a functional, sprayable solution. This type of chemical treatment obviousiy increases the risks involved with the handling of hazardous materials, such as the strong base and acid used. This danger is avoided when pregelled potato starch is used.

The other product selected for evaluation is a mixed solution of simple sugars and complex polysaccharides derived as a byproduct of sugar beet processing. It is available under the trademark XDCA from Syntec, Inc. It is a thick, brown liquid with a distinct, sweet aroma, that can be diluted to form a sprayable liquid. The concentrate is readily miscible in water, making for easy handling, application, and clean-up of equipment. 
Actual application costs of a dust suppression product is obviously dependant on both the concentration of the product and the amount of product applied per unit area of soil and on the intended function of the material. However, some comparisons can be made of the costs of the natural polysaccharides with other commercially available materials. The potato starch costs approximately $\$ 1.10 / \mathrm{Kg}(\$ 0.50 / 1 \mathrm{~b})$, so the application cost is approximately $\$ 0,06 / \mathrm{m}^{2}\left(\$ 0.05 / \mathrm{yd}^{2}\right)$ for a $2.5 \%$ (by weight) starch solution applied at $2 \mathrm{~L} / \mathrm{m}^{2}$. $\left(0.5 \mathrm{gal} / \mathrm{yd}^{2}\right)$. The XDCA sugar beet concentrate costs approximately $\$ 0.13 / \mathrm{L}(\$ 0.50 / \mathrm{gal})$ in bulk, for an application cost of approximately $\$ 0.17 / \mathrm{m}^{2}\left(\$ 0,16 / \mathrm{yd}^{2}\right)$ if the concentrate is diluted $1: 2$ with water and applied at $4 \mathrm{~L} / \mathrm{m}^{2}\left(1 \mathrm{gal} / \mathrm{yd}^{2}\right)$. For comparison, the application costs of 2 other products each applied at the Hanford Site include the following to an area approximately $1,700 \mathrm{~m}^{2}\left(2,000 \mathrm{yd}^{2}\right)$.

- A tall-oil pitch-type product would cost $\$ 0.54 / \mathrm{m}^{2}\left(\$ 0.45 / \mathrm{yd}^{2}\right)$.

- A polyvinyl acetate would cost approximately $\$ 0.93 / \mathrm{m}^{2}\left(\$ 0.78 / \mathrm{yd}^{2}\right)$.

Winberg and Wixom (1992) estimated application costs for several types of dust control agents including the following:

- Petroleum hydrocarbon emulsion, $\$ 0.76 / \mathrm{m}^{2}\left(\$ 0.64 / \mathrm{yd}^{2}\right)$

- Tall-0il pitch would cost $\$ 0.78 / \mathrm{m}^{2}\left(\$ 0.65 / \mathrm{yd}^{2}\right)$

- Calcium lignosulfonate at $\$ 1.00 / \mathrm{m}^{2}\left(\$ 0.84 / \mathrm{yd}^{2}\right)$.

The costs for all of these products probably would be reduced if the materials were purchased in bulk quantities. For instance, a tal1-0il pitch was applied to several tank farms on the Hanford Site during 1993. At least 189,000 L $(50,000 \mathrm{gal})$ of material were purchased at $\$ 0.25 / \mathrm{L}$ ( $\$ 0.94 / \mathrm{gal})$. Bids received ranged up to $\$ 0.53 / \mathrm{L}(\$ 2.00 / \mathrm{gal})$, for a final application cost of approximately $\$ 0.24 / \mathrm{m}^{2}\left(\$ 0.20 / \mathrm{yd}^{2}\right)$.

Although the comparison of application costs suggests that the use of natural polysaccharides may result in considerable cost savings, the intended performance of these products are actually quite different. Most commercial products are purchased with the intention of controlling dust generation for at least several months with one application, and products with long functional lives and products that are not washed out of the soil are usually the most desirable. The natural polysaccharides have shorter lives in the environment, and their period of effectiveness is more limited. However, that short functional life may be an asset in an active excavation or remediation setting, especially if waste reduction and minimization are part of the ultimate clean-up goal.

\subsection{PRODUCT EVALUATION PROCESS}

The effectiveness and utility of the potato starch and XDCA were evaluated using a combination of field trials and demonstrations, wind-tunnel tests, and laboratory physical property analyses. Each of these are described in detail in subsequent chapters of this report. The field tests included both small-scale, proof-of-principle tests, and large-scale demonstrations in 
conjunction with the field deployments of the Remote Retrieval System and CCU within the overall Buried Waste Integrated Demonstration (BWID) at INEL. These tests were performed to evaluate different product concentrations and application rates and to demonstrate the effectiveness and utility of the products under various specific situations encountered in a waste-retrieval environment.

Wind-tunnel evaluations were performed to quantitatively assess the erosion protection provided by the starch and sugar beet products. These tests were performed at the wind-tunnel facility operated by the Pacific Northwest Laboratory (PNL). The laboratory analyses of physical properties were designed to determine the ease of removing the selected products with water from various soil types. These tests were performed in the Geotechnical Engineering Laboratory operated by Westinghouse Hanford Company (WHC).

All of the evaluations indicated that both of the products can be useful for dust suppression and the control of contaminant spread. The evaluations indicate that both products offer significant erosion protection and that neither will interfere with a soil-washing system. 
WHC-EP-0688

\subsection{FIELD TRIALS AND DEMONSTRATIONS}

Several field tests and demonstrations were performed to evaluate the utility of the potato starch and sugar beet products as dust-control or soil-fixative agents. The solubility of the products and mixing procedures for each were evaluated, followed by proof-of-principle field tests and, finally, full-scale field demonstrations.

\subsection{PRODUCT SOLUBILITY TESTS AND SOLUTION FREPARATION}

The XDCA product was found to be readily miscible in water and required only slight agitation to produce a homogeneous solution that would remain stable for at least several months. The $p$ tato starch required considerably more effort to produce a homogeneous solution. Cool water was preferable to warm or hot water, and the material needed to be added slowly with continual agitation to avoid forming globular aggregations that were difficult to break up or dissolve. Better results can be obtained using a high speed blender. For Hanford Site purposes, the water and dry material can be added together in bulk and then be blended for approximately 30 seconds. Using this procedure, a homogeneous 10\%-by-weight starch solution is easily obtained, and this thick solution could be readily diluted to the desired application concentration (i.e., 1 or 2.5 percent) with minimal mechanical effort.

The final starch solution is viscous and translucent and has an oily or slimy texture. The solution is stable for about 2 days at room temperature following preparation, at which point a white precipitate begins to form, and the solution turns cloudy. Once the precipitate forms, the solution does not appear to be as effective as a dust-control agent as it is before the phase change. The precipitation may be prevented by adding a preservative, by chemically altering the solution in some other manner, or by storing the starch solution at a different temperature. These procedures were not attempted.

An optimal method for large-scale preparation of starch solutions has not been identified. However, this is viewed as an engineering problem that is beyond the primary scope of this work. Equipment from the food or chemical industries could undoubtedly be modified or adapted for large-scale production of starch solutions.

\subsection{SMALL-SCALE FIELD TESTS}

Small field plots were established in early December 1992, to evaluate the effectiveness of the XDCA and potato starch products under field conditions and to determine an appropriate range of concentrations and application rates to be used in subsequent field and laboratory testing. The plots were laid out in a coarse sandy site at the Hanford Geotechnical Development Test Facility.

The potato starch was applied to four $6-\mathrm{m}^{2}$ plots, at two application rates $\left(1 \mathrm{~L} / \mathrm{m}^{2}\right.$ and $\left.2 \mathrm{~L} / \mathrm{m}^{2}\right)$ and at two product concentrations ( 1 and 2.5 -percent starch by weight). The solutions were applied to the soil surface using a 
backpack hand-pump sprayer. Before application, the plots were raked to break up any surface water or wind-crust present. After application, a distinct starch crust was detectable on all four of the test plots within approximately 30 minutes, even though the ambient air temperature was low $\left(4^{\circ} \mathrm{C}\right)$. As expected, an increase in the application rate and/or the product concentration resulted in a thicker, stronger crust. Evaluations of the longevity of the crusts was comp?icated by record amounts of snowfall that occurred within days of application, and which persisted on the ground for the following 6 weeks. At the end of January 1993, the crust was still evident on the plot that had received $2 \mathrm{~L} / \mathrm{m}^{2}$ of 2.5-percent starch solution but had deteriorated on the other plots.

The XDCA was tested on nine $1-\mathrm{m}^{2}$ plots. Three application rates $\left(2 \mathrm{~L} / \mathrm{m}^{2}\right.$, $3 \mathrm{~L} / \mathrm{m}^{2}$, and $4 \mathrm{~L} / \mathrm{m}^{2}$ ) and three dilution rates (1:5, $1: 3$, and $1: 2$, XDCA:water) were evaluated. These solutions also were applied with the backpack sprayer, and the soil was raked before application. In all cases, the solution completely soaked into the coarse sand, and a distinct crust was not evident. Even without a detectable crust, the product was more apparent in the plots with higher product concentrations and/or higher application rates. At the end of January 1993, some of the plots were still covered with snow, and the product appeared to have been completely leached from the plots that were free of snow cover.

Although the overall utility of these data were limited by the snow cover that occurred shortly after application, the ranges of product. concentrations and application rates were deemed appropriate for further field ciemonstrations, laboratory analyses, and wind-tunnel evaluations.

\subsection{LARGE-SCALE FIELD DEMONSTRATIONS}

Large-scale demonstrations of the XDCA and potato starch were conducted at the INEL BWID Cold Test Pit in conjunction with the field demonstrations of the CCU, Remote Retrieval System, and the Rapid TRU Monitoring Unit. Several specific objectives for the polysaccharide soil-fixative portion of this co-demonstration were enumerated by Morrison and Heard (1993). These objectives included following.

- Evaluate the effectiveness of the material used in the wasteretrieval environment.

- Evaluate the response time and the ability of the materials to immobilize surface contamination or removing airborne contamination.

- Evaluate the extent that the material is incompatible with other necessary functions during the waste retrieval operations.

- Evaluate the extent that the material generates additional waste volume or mass.

In general, both of the products were effective in the simulated waste-retrieval environment of the cold-test pit. They also were compatible with all of the equipment that was in operation, and neither product increased waste generation. 
The most useful byproduct of the co-demonstration was the resultant capability to directly compare the natural polysaccharide products with the commercially available materials that had been independently selected for demonstration with the CCU (i.e., calcium lignosulfonate and a dustsuppressant foam). The demonstrations conducted allowed the XDCA to be compared directly with the calcium lignosulfonate (Flambinder') because both were used for general dust suppression in foot- and vehicular-traffic areas inside and outside of the containment tent, and both materials were applied using the main. tank and spray system of the CCU. The potato starch was directly comparable to the foam product (3M Foamer ${ }^{2}$ ) because these were used for dig-face stabilization within the excavation pit itself.

\subsubsection{Comparison of XDCA with Calcium Lignosulfonate}

The XDCA was first applied with the CCU spray system to approximately $500 \mathrm{~m}^{2}$ near the edge of the cold-test pit. The XDCA was applied at a dilution of $1: 2$ and an application rate of about $4 \mathrm{~L} / \mathrm{m}^{2}$. When applied to a dry surface, the XDCA dried in less than 1 hour, but the resulting crust did not withstand traffic of any kind. When applied to premoistened soil it took longer to cure, but the resultant crust easily withstood foot traffic, although it lost its integrity after 2 or 3 vehicular passes. Therefore, it was determined that the product should be applied to premoistened soil to increase the infiltration into the soil. Reapplication of the product to the treated area improved its ability to withstand traffic.

The XDCA did not hold up well in rain. Shortly after the product was initially applied rain fell for several days. Some of the product leached into the soil, but most of it was wa: led downslope. The large amount of product runoff probably was caused by the fine silty nature of the cold-test pit soil; if the cold-test pit had contained coarse sand, most of the product probably would have been leached into the soil.

A comparable, although flatter, area adjacent to the cold-test pit was treated with Flambinder calcium lignosulfonate. This product was applied at a $1: 4$ dilution at an application rate of approximately $4 \mathrm{~L} / \mathrm{m}^{2}$. The crust resulting from this product could withstand foot traffic after a curing time of 1 to 2 hours, and it was cured completely within 2 days. In general, the calcium lignosulfonate withstood traffic better than the XDCA, al though both were disrupted under repeated vehicular traffic. The calcium lignosulfonate also withstood rainfall better. In areas where the surface was not completely cured, some leaching into the soll occurred, but in the fully cured areas the crust integrity was reasonably well maintained after the rainfall.

During the excavation phase of the BWID co-demonstration, XDCA was applied both inside and outside the containment tent. The outdoor application successfully reduced the amount of nuisance dust entering the containment structure from the open soil surfaces to the south and west of the tent. This

\footnotetext{
${ }^{1} \mathrm{Flambinder}$ is a tradename of $\mathrm{Flambeau}$, Corp.

${ }^{2} 3 M$ Foamer is a tradename of $3 M$ Company, Inc.
} 
WHC-EP-0688

application heid up well to repeated foot traffic, and the dust-suppression ability did not appear to be compromised seriously by repeated vehicular passes.

XDCA also was applied to one-half the soil within the BWID containment tent (approximately $250 \mathrm{~m}^{2}$ ). The soil was premoist. ned, and the diluted product solution $(1: 2)$ was applied at approximately $4 \mathrm{~L} / \mathrm{m}^{2}$. The area was completely cured within 2 to 3 days but was able to withstand foot traffic within 16 hours. The dust-control effectiveness of the appilication was acceptable, and the minor amount of disturbance caused by the movement of the backhoe did not appear to greatly decrease the dust-control efficiency of the application.

The other half of the interior of the containment tent was treated with a Flambinder solution (1:4); it had comparable curing times and characteristics as the XDCA. The Flambinder solution also held up well to foot- and lightvehicular traffic and appeared to maintain integrity longer than the XDCA.

For the general dust-suppression requirements of the BWID retrieval demonstration, the calcium lignosulfonate is preferable over the XDCA, although both performed adequately. Both products were readily solubie, vere easy to apply, and were easy to clean up. The calcium lignosulfonate is preferred in this case because it withstood traffic better, holds up better to rainfall, and (as delivered for this test) was less expensive. The cost per barrel of the two products was comparable, but the Flambinder could be diluted with twice as much water and, thiarefore, covered twice as nuch area. The primary disadvantage of the Flambinder was that the concentrated product was so thick that it could not be pumped directly into the CCU holding tanks using the available pumps; instead it had to be poured into buckets to be transferred to the CCU. The preference for calcium lignosulfonate over XDCA is situation specific. If some subsequent soil treatment is planned, XDCA may be preferred because it is easier to remove from the soil.

\subsubsection{Comparison of Potato Starch and Dust-Suppression Foam}

The potato starch and the dust-suppressant foam (3M Foamer) were used to stabilize the dig face and to provide contaminant control within the relatively small excavation pit. The potato starch also was demonstrated at several locations outside the excavation pit.

The starch was mixed inside a 25-gal (94.6-L) portable spray unit by slowly adding the granulated starch to water while continuously agitating with a paint mixer. Some small clumps of material remained in the liquid, but these did not block the spray nozzle. Outside the containment structure, a 2.5-percent starch solution was applied to a flat, low-traffic area, and to two steep, loose-soil surfaces. The starch mixture dried completely within several hours outside, eventually resulting in a $0.5-\mathrm{cm}$ crust that maintained its integrity for at least 1 week. The crust was broken easily with foot traffic. On the steep slopes, the crust adhered well to the soil surface and started to run only if excessive amounts were applied.

The potato starch also was applied to two of the test cells that were excavated with the remote excavation system. Airborne dust measurements were 
collected during these tests, but because of numerous logistical and environmental complications, the utility of these data is limited. The soil within the excavation was aiso fairly damp, which reduced the amount of dust generated by the excavation process. Cell 3 of the cold-test pit did provide some comparative results. One half of this cell was treated with 2.5-percent potato starch solution, and the other half was left untreated. Starch applications were repeated while each box of excavated soil and simulated waste was removed from the pit. The starch adhered well to the vertical walls of the excavation and, when a portion of the soil was removed, the adjacent crust was left und isturbed and maintained its integrity. The dust monitoring performed during the excavation of this cell indicated that the potato starch reduced the amount of airborne just by up to 56 percent. Potato starch also was applied to cell 1 of the cold-test pit, and the qualitative results observed were similar to those from cell 3. Logistical complicat ons during the retrieval of coll 1 rendered the dust-monitoring results inconclusive.

3M Foamer was applied to cell 4 of the cold-test pit retrieval demonstration. This product fast to apply, and it quickly (within minutes) formed a complete seal cver the ireated soil. However, because of the physical properties of the resulting surface matrix, a single scoop with the backhoe bucket removed most of the surface crust, even from areas well removed from the point of bucket entry into the soil. The effect is similar to pulling a blanket off the surface. Obviousiy, once the surface crust was removed, the remaining soil surfaces within the pit were unprotected and subject to dust generation. Again, the dust-monitoring results from this cell were inconclusive because of extraneous complications resulting from the multiple co-demonstration. Aside from the limited effective duration of the protective soil cover, an additional disadvantage of the $3 M$ Foamer was the requirement that the application personnel wear Type A personal protective equipment. Although this could be required in an actual transuranic-wasteretrieval environment anyway, in many other retrieval and excavation settings this protective equipment requirement would be an added logistical burden to the remediation process.

Based on these observations, the potato starch is preferable over the 3M Foamer for dig-face stabilization. The potato starch crust maintains its integrity during the excavation, meaning less material and fewer applications would be needed compared to the $3 M$ Foamer. The use of potato starch does not require application personnel to wear any special protective equipment. The potato starch crust does not withstand traffic well, but this type of disturbance is unlikely to be encountered on an excavation dig face. The primary disadvantage of the potato starch is the difficulty in producing large quantities of sprayable solution. The developinent of an efficient method for doing so would be a worthy pursuit. 
WHC-EP-0688

This page intentionally left blank. 
WHC-EP-0688

\subsection{WIND TUNNEL EVALUATIONS}

Evaluations of the degree of erosion protection provided by potato starch and XDCA crusts were performed at the Aerosol Wind Tunnel Facility, operated by PNL. Wind-tunnel evaluations allow for quantitative comparisons of different products, concentrations, application rates, and soil types under known and controlled erosive-stress conditions. This type of testing also allows for evaluations of surface protection under extreme conditions that would be difficult to replicate or control in the field.

A total of 69 tests were performed to analyze such factors as type of crusting agent, product concentration and application rates, aging or weathering conditions, and different soil types. Most of the tests were performed using soll obtained from the INEL cold-test pit and addressed comparisons of product type, concentration, and application rate. A standard concentration and application rate was selected for each product to evaluate the effects of different weathering conditions and to compare the INEL soil with a Hanford Site sandy soll. Summaries of the procedures and results are provided in the following sections; and the complete report prepared by PNL is attached to this report as Appendix $A$.

\subsection{EVALUATION METHODS}

Test surfaces were prepared by placing $9,300 \mathrm{~g}$ of INEL soll or 9,500 $\mathrm{g}$ of Hanford Site soll into a $255-\mathrm{cm}^{2}$ stainless steel tray and by compacting the soil to form a layer approximately $3.2 \mathrm{~cm}$ deep. The top of the soil layer was approximate $1.3 \mathrm{~cm}$ above the sides of the tray. The edges of the soil layer were sloped to reduce edge-effect stresses on the surface. Dry controls were prepared to evaluate mass loss with wind speed, and wet controls for each soil type were prepared by spraying the packed surface with $2 \mathrm{~L}$ of water to enhance the formation of a water crust. These water-crust, or wet-control, surfaces were used as a basis for evaluating the effectiveness of the starch and XDCA crusts.

Treated surfaces were sprayed with a preselected concentration and amount of either potato starch or XDCA. A few tests were performed using a fermented potato waste product under development by PNL; these results are not considered in this summary but are included in appendix $A$. After the products were applied, the surfaces were aged in a plant-growth chamber for 4 days under a diurnal cycle consisting of a 14-hour 1 ight period at $40^{\circ} \mathrm{C}$ and a 10 -hour dark perlod at $20^{\circ} \mathrm{C}$. The trays were periodically weighed during aging to ensure that the soil moisture content during the wind-tunnel evaluations was consistent throughout the differen: tests.

The effects of two additional weathering factors that could affect crust integrity also were examined in a small subset of the tests. The effect of ultraviolet (UV) radiation was examined by providing supplemental UV irradiation curing the light periods of the diurnal cycle. These evaluations were performed because both of the products are organic polymers that colld be broken down by UV radiation from sunlight in the field. Other selected surfaces were subjected to a moisture cycle to simulate rainfall effects on the surface crusts. These surfaces were allowed to dry normally for 3 days 
and then were sprayed with $0.5 \mathrm{~L}$ of water per tray on each of the next 3 days. The surfaces then were allowed to dry normally for 4 days after the third simulated rainfall event.

After aging, the surfaces were exposed to as many as eight successively higher levels of stress in the wind tunnel. After each subtest, the mass loss from the surface was determined, and then the tray was returned to the wind tunnel for the next subtest, uniess the surface had been judged to have falled. A surface was considered failed if any portion of the sample tray was exposed, if a large portion of the surface crust had been removed leaving unprotected soll, or if the total mass loss was $2000 \mathrm{~g}$ or greater. The first 4 subtests were (1) $20 \mathrm{~m} / \mathrm{s}$ wind, (2) $25 \mathrm{~m} / \mathrm{s}$ wind, (3) $20 \mathrm{~m} / \mathrm{s}$ wind $+10 \mathrm{~kg}$ sand, and (4) $25 \mathrm{~m} / \mathrm{s}$ wind $+15 \mathrm{~kg}$ sand. Each subtest lasted for 2 minutes. In subtests 3 and 4 , the sand was placed upwind of the test surface and was allowed to pass over the crust. If the surface survived the first four subtests, the crust was then disturbed by creating a regular grid of depressions $1.2 \mathrm{~cm}^{2}$ by $0.7 \mathrm{~cm}$ deep, spaced $2.5 \mathrm{~cm}$ apart, using a plexiglass tool. This was not intended to sim'slate any specific type of field disturbance, but was instead meant to provide a uniform, repeatable type of disturbance to the surface crust. After disturbance, the test surfaces were returned to the wind tunnel for the next four subtests. The parameters used for subtests 5 through 8 were the same as those used in subtests 1 through 4 .

\subsection{EVALUATIONS OF SURFACE CRUSTS ON INEL SOIL}

Soll obtained from the INEL cold-test pit was used for the analyses of product concentration and application rates and for comparisons of different types of weathering conditions. Potato starch was evaluated at concentrations of 1 and 2.5 percent, and at application rates of 1,2 , and $4 \mathrm{~L} / \mathrm{m}^{2}$. A $1: 2$ dilution of XDCA was evaluated at application rates of $1.1,4.5$, and $9.2 \mathrm{~L} / \mathrm{m}^{2}$, and a $1: 1$ difution of XDCA was evaluated at an application rate of $4.5 \mathrm{~L} / \mathrm{m}^{2}$.

The only potato starch crust that did not provide significantly better erosion protection than the wet control was the application of $1 \% 01 \mathrm{~L} / \mathrm{m}^{2}$. All of the other potato starch crusts provided significantly better surface protection than the wet control. The 2.5-percent solutions were found to provide greater protection than the 1-percent solutions, even at low application rates. This may be because the 1-percent solution washed the starch deeper into the soll, reducing the strength of the surface crust. Increasing the volume of 2.5-percent solution did not improve the erosion protection, which also suggests that the starch may be washed deeper into the soil with increasing water volumes. The best crust was produced using a high-starch concentration (2.5 percent) and low application volume $\left(1 \mathrm{~L} / \mathrm{m}^{2}\right)$. Many of the potato starch surfaces had negative deflation rates when exposed to saltating sand, indicating that the sand was being trapped by roughness on the surface crust. This was especially apparent on the disturbed surfaces.

The XDCA did not perform as well as the potato starch on the INEL soll. None of the XDCA cases performed significantly better than the wet control, except for the application rate of $9.2 \mathrm{~L} / \mathrm{m}^{2}$, which provided only modest protection. The $1 \mathrm{~L} / \mathrm{m}^{2}$ of $1: 2$ solution appeared to provide less protection than the water crust of the wet control. Increasing the concentration of the solution to $1: 1$ did not improve the performance. 
WHC-EP-0688

Applications of $1 \%$ (potato starch) $2 \mathrm{~L} / \mathrm{m}^{2}$ and $2: 1$ XDCA at $4.5 \mathrm{~L} / \mathrm{m}^{2}$ were used to evaluate the effects of UV radiation and moisture cycling on surface crust performance. Both the UV and moisture cycle treatments appeared to reduce the effectiveness of the XDCA crusts compared to the normally aged surfaces, but the results were not significantly different from the wet control. The UV treatment had no effect on the potato starch crust. The performance of the potato starch crust was reduced by the moisture cycle treatment.

\subsection{EVALUATIONS OF SURFACE CRUSTS ON HANFORD SITE SANDY SOIL}

The Hanford Site soil has a higher sand content than the INEL soil, which means that the Hanford Site soil is more erodible. This is supported by the finding that under the $20 \mathrm{~m} / \mathrm{s}+$ sand case (subtest 3 ) the erosion by wind of the wet-control Hanford Site soll was about 170-fold greater than the INEL wet control. Tests on Hanford Site soll were performed using wet controls, potato starch $\left(1 \% \circ 2 \mathrm{~L} / \mathrm{m}^{2}\right)$, and XDCA $\left(1: 2 \odot 4.5 \mathrm{~L} / \mathrm{m}^{2}\right)$.

The results of the tests on Hanford Site soil proved to be entirely different from those obtained using INEL soll. Although the potato starch provided significant erosion protection on both undisturbed and disturbed INEL soil, it provided little protection on the Hanford Site soil, even if the crust was undisturbed. Conversely, the XDCA provided virtually no acded protection on the INEL soil, but it provided extraordinary protection on the Hanford Site soil, even after disturbance. Because this result was considered surprising, one of the XDCA surfaces that had survived subtest 8 was subjected to a modified moistire cycle and was re-aged. Even after the molsture cycling XDCA still provided a high degree of erosion protection to the Hanford Site sandy soil under all of the test conditions.

\subsection{CONCLUSIONS}

Potato starch was found to provide significant erosion protection to the INEL soli. Surface protection was not found to be a simple function of the total quantity of starch applied because the best crusts were created with a high starch concentration $\left(2.5\right.$ percent) and a low application volume $\left(1 \mathrm{~L} / \mathrm{m}^{2}\right)$. Increasing the volume of 2.5-percent solution applied did not result in increased protection. On the Hanford Site sandy soll, the potato starch provided limited erosion protection, and the crusts failed under the most stressful conditions. It is unknown if a higher concentration solution or greater application volume would have resulted in a more resistant potato starch crust on the Hanford Site soll. UV radiation did not effect the performance of the potato starch on INEL soil, but moisture cycing did result in reduced levels of performance. This indicates that a potato starch crust will probably not hold up well to repeated rainfall events in the field.

XDCA provided virtually no protection to the INEL soil, but performed well on the Hanford Site soll. Neither the UV nor the moisture cycling treatments had significant effects on the XDCA performance on INEL soil, which was not surprising because the normally aged surfaces had performed so poorly. A moisture cycle did not greatly reduce the remarkable effectiveness of the XDCA on the Hanford Site soll. 
The physical conditions that these tests were performed under were meant to simulate extreme environmental conditions in the field. The wind speeds used in these tests were selected based on an analysis by Ligotke (1993) of the surface sheer stress that would result from 1,000-year peak gusts at the Hanford Site. The selected wind speeds were intended to bracket the sheer stresses imparted by a 100-year peak wind gust. To extrapolate to field scale, the sheer stresses imparted to the tests surfaces during the most stressful wind-tunnel tests $(25 \mathrm{~m} / \mathrm{s}+\mathrm{sand})$ are comparable to the stresses imparted in the field by a 2-minute 95-mph $(153 \mathrm{~km} / \mathrm{h})$ sand storm. Therefore, failure of a crust under these extreme conditions does not necessarily mean that the product would not provide adequate protection under more normal field conditions.

The results of these tests indicate a significant interaction between soil type and the level of erosion protection that a particular dust-control agent can provide. A product that performs perfectly on one soil type may not be ideal on a different soll. 


\subsection{LABORATORY ANALYSES}

The utility of any dust-suppression or contaminant-control agent may be limited in an active remediation setting if the material interferes with subsequent waste or soil treatments. This report assumes the soil treated with a dust control agent will eventually be subjected to soil washing. This waste-reduction technique operates on the principle that many radioactive contaminants will adhere preferentially to the fine silty particles in a soil instead of the coarser sand or gravel particles. Soil-washing functions by separating the fine from the coarse material, thereby concentrating the contaminants in the fine-particle portion. A dust-suppressant material that produces a relatively insoluble crust would cause the fine particles (with the associated contaminants) either to adhere to the larger particles or to agglomerate into particles that are effectively larger. The silt material thus would be separated from the soil with the larger sand and gravel portions, contaminating the portion that is supposed to be clean and reducing the efficiency of the soil-washing system.

The solubility of potato starch and XDCA crusts, and their relative effect on particle separation was evaluated by the Geotechnical Engineering Laboratory, operated by WHC. The ease with which the materials could be removed from soils was analyzed by comparing the particle-size distributions of untreated soil with soil that had been treated with potato starch or XDCA. Both dry and wet sieve analyses were performed. Comparing the distributions obtained from the treated soll with the untreated control allows for an estimate of the effect of the dust suppressant on a soil-washing system, and comparing the dry with the wet sieve results allows for an estimate of the ability to remove the product from the soil. Three soil types were used in these analyses: silty soil obtained from the INEL cold-test pit, a sandy soil from the central portion of the Hanford Site, and a silty soil from the western portion of the Hanford Site.

\subsection{SAMPLE PREPARATION AND ANALYSIS}

Samples were prepared by placing a thin layer of soil, approximately $2 \mathrm{~cm}$ deep, in a $500 \mathrm{~cm}^{2}$ aluminum pan. The soil was then treated with either a light or heavy dose of the potato starch or XDCA. The light dose of potato starch was $1 \mathrm{~L} / \mathrm{m}^{2}$ of 1-percent solution, and the heavy dose was $2 \mathrm{~L} / \mathrm{m}^{2}$ of 2.5-percent solution. The light dose of XDCA was $2 \mathrm{~L} / \mathrm{m}^{2}$ of a $1: 5$ dilution, and the heavy XDCA dose was $4 \mathrm{~L} / \mathrm{m}^{2}$ of a $1: 2$ dilution. The pan of treated soil was oven dried at $105{ }^{\circ} \mathrm{C}$ for 16 hours to accelerate crust formation. The soil samples were then split and dry and wet sieved.

Dry sieving was performed by placing one half of each oven-dried soil sample in a sieve stack and shaking for 10 minutes. The percentage of material weight retained by each sieve then was determined and the percent passing each sieve was calculated. The other half of each sample was wet sieved following the same procedure used for the dry sieve analyses, with the exception that a stream of water was passed over the sample while the sample was being shaken. The results of these analyses, are provided in Tables 4-1 through 4-3. 
WHC-EP-0688

\subsection{INEL COLD-TEST PIT SOIL}

All of the INEL silty soil completely passed a 19.050-mm sieve when dry sieved and a 4.75-mm (\#4) sieve when wet sieved. In the dry sieve analysis, a small portion of the starch-treated soil was retained by the $9.525-\mathrm{mm}$ sieve; none of the XDCA treated or control soil was retained by this sieve.

When dry sieved, the INEL silty soil samples that had been treated with either potato starch or XDCA had significantly less material passing nearly all of the sieves, indicating that the soil particles were strongly held together by the dust suppressant agents (Table 4.1). Wet sieving greatly reduced the differences between the treated and control soil particle size distributions. In general, the biggest differences between the treated and control samples occurred at the two finest sieve sizes. The percent of treated soil material passing these sieves was approximately 20 percent less than the control.

The starch treatments did not have a significant effect on the percent passing the larger sieve sizes (i.e., sieves \#4 - \#60), and the amount of starch applied did not greatly alter the results. XDCA treatments reduced the percentage passing the $\# 40$ and $\# 60$ sieves $(0.425 \mathrm{~mm}$ and $0.250 \mathrm{~mm}$, respectively) by about 5 percent in the light-application dose and about 10 percent for the heavier dose.

\subsection{HANFORD SITE SANDY SOIL}

All of the Hanford Site sandy soil samples that were untreated or treated with potato starch had 100-percent passage through the $9.525-\mathrm{mm}$ screen when dry sieved. Slightly less than 1 percent of the soil treated with the light dose of XDCA was retained by the $9.525-\mathrm{mm}$ dry sieve, and slightly less than 5 percent of the soil treated with the heavy dose of XDCA was retained by the 19.050-mm dry sieve. When wet sieved, all of the treated and control soil samples had 100-percent passage through the 4.750-mm (\#4) sieve.

Neither of the starch treatments greatly altered the dry sieve particlesize distribution of the Hanford Site sandy soil compared to the untreated controls (Table 4-2). The 1 ight XDCA dose reduced the percent passing dry sieves \#40 through \#200 by approximately 5 percent, while the heavy XDCA dose reduced the percent passing through all of the sieves by approximately 30 percent. When wet sieved, both of the starch doses reduced the percent passing sieves $\# 60$ through $\# 200$ by 5 to 10 percent compared to the control soil, but the values for the larger sieves of the starch treatments and the control are comparable. The XDCA treatments reduced the wet sieve percent, passing sieves \#40 through 200 by approximately 4 to 13 percent, compared to the control.

\subsection{HANFORD SITE SILTY SOIL}

The dry sieve analysis of the Hanford Site silty soil indicated that all of the control and treated soil, except for the sample treated with a heavy dose of XDCA, passed the 19.050 $\mathrm{mm}$ sieve. Approximately 2.5 percent of the heavy dose of XDCA sample was retained by that sieve. As found in the other 
two soil types, wet sieving resulted in 100-percent passage through the \#4 or $4.750-\mathrm{mm}$ sieve for the control and all of the treated soil samples. Both of the starch doses slightly reduced the percentage passing all of the sieves by up to about 6 percent, compared to the dry sieve control (Table 4-3).

When wet sieved, the starch treatments reduced the percent of material passing the \#10 sieve by about 5 percent and the percent passing the finer screens by 11 to 14 percent, compared to the wet sieve control. Both of the dry and wet sieve procedures resulted in similar particle-size distributions for the potato-starch-treated Hanford Site silty soil. Both of the XDCA treatments reduced the percent of material passing all of the dry sieves when compared to the control, with a much greater reduction caused by the heavy dose. The wet sieve particle-size distributions of the two XDCA treatments were very similar, and both were remarkably similar to the wet sieved starch treated samples. The main alteration to the wet-sieve particle-size distributions appears to have occurred at the larger sieve sizes, especially \#40, because the percent retained by each of the successively finer sieves is similar in the control and treated samples; that is, the absolute difference between the values for sieves \#60 and \#100 or \#100 and \#200 is similar for the control and treated samples.

\subsection{CONCLUSIONS}

The specific cut-off particle size for segregation of contaminated from clean soil by a soil washing system is related to a number of factors, but is especially dependant on the soil type and particle-size distribution of the soil being remediated. At the Hanford Site, the cut-off point is believed to roughly correspond to a \#40 sieve, or a particle size of approximately $0.425 \mathrm{~mm}$. The values obtained for this sieve size are highlighted in Tables 4-1 through 4-3. Using this cut-off point as a baseline for predictions, neither the potato starch nor the XDCA should greatly effect the efficiency of soil washing the Hanford Site sand (Table 4-2). The potato starch will probably not greatly effect soil washing of the INEL cold-test pit soil (Table 4-1), while XDCA would result in a slight loss in efficiency. Both the starch and XDCA would decrease the soil-washing efficiency if this technique were used on the Hanford Site silty soil (Table 4-3).

These results suggest that these products may create problems for the remediation of a silty soil. However, soil washing may not be an effective treatment technique for silty soils and in general is probably most useful for sandy soils. The particle-size cut-off point for silty soils used may be something other than $0.425 \mathrm{~mm}$. A full-scale soil washing system may allow for greater disintegration of agglomerated fine-soil particles compared to the wet-sieve method used in these tests by increasing the amount of agitation, lengthening the time of soil/water contact, or by passing relatively greater volumes of water through the soil. Any of these alterations could increase the efficiency over that estimated by these sieve analyses.

Either of the products can be used on sandy soils without effecting soil washing efficiency. The potato starch can be used on the INEL silty soil if the particle-size cut-off point is $0.250 \mathrm{~mm}$ or greater. XDCA could al so be used on the INEL soil, but a slight decrease in efficiency will probably occur. Both of the products may seriously reduce the efficiency of soil 


\section{WHC-EP-0688}

washing of the Hanford Site silty soll. This is an excellent example of the need to perform these or similar analyses before using a dust-suppressant agent at a remediation site, if a subsequent soil treatment is planned. 
Table 4-1. INEL Silty Soil - Percent Passing, Dry and Wet Sieve Procedures.

\begin{tabular}{|c|c|c|c|c|c|c|c|c|c|c|}
\hline \multirow{2}{*}{$\begin{array}{l}\text { Sieve } \\
\text { Size } \\
(\mathrm{mm})\end{array}$} & \multicolumn{2}{|c|}{ Control } & \multicolumn{2}{|c|}{$\begin{array}{c}\text { Starch } \\
\left(1 \%, 1 \mathrm{~L} / \mathrm{m}^{2}\right)\end{array}$} & \multicolumn{2}{|c|}{$\begin{array}{c}\text { Starch } \\
\left(2.5 \%, 2 \mathrm{~L} / \mathrm{m}^{2}\right)\end{array}$} & \multicolumn{2}{|c|}{$\left(1: 5,2 \mathrm{XDCA} / \mathrm{m}^{2}\right)$} & \multicolumn{2}{|c|}{$\left(1: 2,4 \mathrm{LDCA} / \mathrm{m}^{2}\right)$} \\
\hline & Dry & Wet & Dry & Wet & Dry & Wet & Dry & Wet & Dry & Wet \\
\hline 19.050 & 100 & 100 & 100 & 100 & 100 & 100 & 100 & 100 & 100 & 100 \\
\hline 9.525 & 100 & 100 & 98.0 & 100 & 95.0 & 100 & 100 & 100 & 100 & 100 \\
\hline $\begin{array}{c}4.750 \\
(\# 4) \\
\end{array}$ & 100 & 100 & 89.8 & 100 & 87.7 & 100 & 97.8 & 100 & 95.0 & 100 \\
\hline $\begin{array}{l}2.000 \\
(\# 10) \\
\end{array}$ & 100 & 99.5 & 81.1 & 99.1 & 76.2 & 99.3 & 85.8 & 99.2 & 84.0 & 98.4 \\
\hline $\begin{array}{r}0.425 \\
(* 40) \\
\end{array}$ & 89.7 & 94.6 & 56.7 & 90.1 & 51.4 & 91.1 & 58.4 & 88.5 & 52.6 & 83.0 \\
\hline $\begin{array}{r}0.250 \\
(\# 60) \\
\end{array}$ & 70.5 & 82.3 & 51.4 & 83.8 & 42.7 & 80.2 & 49.4 & 79.2 & 39.4 & 73.1 \\
\hline $\begin{array}{r}0.150 \\
(\# 100) \\
\end{array}$ & 58.4 & 81.1 & 36.9 & 57.9 & 31.3 & 68.0 & 36.5 & 69.4 & 31.1 & 62.8 \\
\hline $\begin{array}{r}0.075 \\
(\# 200) \\
\end{array}$ & 38.6 & 67.4 & 22.7 & 44.5 & 19.5 & 46.8 & 22.5 & 48.7 & 20.1 & 41.4 \\
\hline
\end{tabular}


Table 4-2. Met Station (Hanford Site) Sandy Soil - Percent Passing, Dry and Wet Sieve Procedures.

\begin{tabular}{|c|c|c|c|c|c|c|c|c|c|c|}
\hline \multirow[t]{2}{*}{$\begin{array}{l}\text { Sieve } \\
\text { Size } \\
\text { (mm) }\end{array}$} & \multicolumn{2}{|c|}{ Control } & \multicolumn{2}{|c|}{$\begin{array}{c}\text { Starch } \\
\left(1 \%, 11 / \mathrm{m}^{2}\right)\end{array}$} & \multicolumn{2}{|c|}{$\begin{array}{c}\text { Starch } \\
\left(2.5 \%, 2 \mathrm{~L} / \mathrm{m}^{2}\right)\end{array}$} & \multicolumn{2}{|c|}{$\left(1: 5,2 \mathrm{XDCA} / \mathrm{m}^{2}\right)$} & \multicolumn{2}{|c|}{$\left(1: 2,4 \mathrm{LDCA} / \mathrm{m}^{2}\right)$} \\
\hline & Dry & Het & Dry & Wet & Dry & Wet & Dry & Wet & Dry & Wet \\
\hline 19.050 & 100 & 100 & 100 & 100 & 100 & 100 & 100 & 100 & 95.3 & 100 \\
\hline 9.525 & 100 & 100 & 100 & 100 & 100 & 100 & 99.3 & 100 & 81.2 & 100 \\
\hline $\begin{array}{c}4.750 \\
(* 4) \\
\end{array}$ & 99.1 & 100 & 99.6 & 100 & 99.1 & 100 & 98.9 & 100 & 71.6 & 100 \\
\hline $\begin{array}{l}2.000 \\
(\$ 10) \\
\end{array}$ & 98.4 & 99.8 & 98.7 & 98.9 & 98.4 & 98.9 & 96.2 & 98.1 & 67.6 & 97.1 \\
\hline $\begin{array}{l}0.425 \\
(\$ 40) \\
\end{array}$ & 86.3 & 86.6 & 86.9 & 86.4 & 83.8 & 85.7 & 80.8 & 83.7 & 52.4 & 82.0 \\
\hline $\begin{array}{l}0.250 \\
(\$ 60) \\
\end{array}$ & 75.3 & 81.7 & 76.9 & 76.8 & 73.8 & 75.7 & 70.3 & 73.5 & 43.0 & 72.1 \\
\hline $\begin{array}{r}0.150 \\
(* 100) \\
\end{array}$ & 62.4 & 73.4 & 63.3 & 65.4 & 61.1 & 63.9 & 57.3 & 61.9 & 32.7 & 60.9 \\
\hline $\begin{array}{r}0.075 \\
(\$ 200) \\
\end{array}$ & 23.9 & 34.8 & 22.9 & 28.0 & 22.6 & 26.8 & 20.9 & 25.9 & 10.7 & 27.5 \\
\hline
\end{tabular}


Table 4-3 McGee Ranch (Hanford Site) Silty Soil - Percent Passing, Wet and Dry Sieve Procedures.

\begin{tabular}{|c|c|c|c|c|c|c|c|c|c|c|}
\hline \multirow{2}{*}{$\begin{array}{l}\text { Sieve } \\
\text { Size } \\
(\mathrm{mm})\end{array}$} & \multicolumn{2}{|c|}{ Control } & \multicolumn{2}{|c|}{$\begin{array}{c}\text { Starch } \\
\left(1 \%, 1 \mathrm{~L} / \mathrm{m}^{2}\right)\end{array}$} & \multicolumn{2}{|c|}{$\begin{array}{c}\text { Starch } \\
\left(2.5 \%, 2 \mathrm{~L} / \mathrm{m}^{2}\right)\end{array}$} & \multicolumn{2}{|c|}{$\begin{array}{c}\text { XDCA } \\
\left(1: 5,2 \mathrm{~L} / \mathrm{m}^{2}\right)\end{array}$} & \multicolumn{2}{|c|}{$\left(1: 2,4 \mathrm{LDCA} / \mathrm{m}^{2}\right)$} \\
\hline & Dry & Wet & Dry & Wet & Dry & Wet & Dry & Wet & Dry & Wet \\
\hline 19.050 & 100 & 100 & 100 & 100 & 100 & 100 & 100 & 100 & 97.4 & 100 \\
\hline 9.525 & 98.6 & 100 & 99.2 & 100 & 98.3 & 100 & 97.6 & 100 & 82.0 & 100 \\
\hline $\begin{array}{c}4.750 \\
(\# 4) \\
\end{array}$ & 95.9 & 100 & 95.1 & 100 & 94.0 & 100 & 91.4 & 100 & 74.4 & 100 \\
\hline $\begin{array}{l}2.000 \\
(\# 10) \\
\end{array}$ & 94.8 & 99.4 & 94.0 & 94.1 & 93.0 & 94.5 & 84.2 & 93.8 & 65.7 & 93.8 \\
\hline $\begin{array}{l}0.425 \\
(\# 40) \\
\end{array}$ & 89.7 & 95.4 & 87.6 & 83.0 & 85.6 & 84.9 & 78.2 & 84.1 & 56.5 & 83.5 \\
\hline $\begin{array}{l}0.250 \\
(\# 60) \\
\end{array}$ & 86.3 & 92.9 & 83.6 & 81.6 & 81.4 & 81.7 & 74.5 & 81.9 & 51.8 & 80.8 \\
\hline $\begin{array}{r}0.150 \\
(\# 100) \\
\end{array}$ & 80.6 & 89.4 & 76.1 & 77.8 & 75.0 & 77.6 & 69.3 & 78.6 & 47.3 & 77.3 \\
\hline $\begin{array}{l}0.075 \\
(\# 200) \\
\end{array}$ & 55.4 & 73.5 & 49.7 & 59.3 & 49.3 & 59.2 & 47.3 & 62.4 & 33.6 & 61.1 \\
\hline
\end{tabular}


WHC-EP-0688

This page intentionally left blank. 
WHC-EP-0688

\subsection{SUMMARY AND CONCLUSIONS}

The work described in this report was designed to identify and evaluate materials that can be used for dust control and for the prevention of contaminant spread during the excavation, retrieval, and remediation of buried waste and contaminated solls. Dust-control agents are needed for use in these types of settings that do not pose any additional environmental risk, are effective for a reasonable period of time, can withstand some degree of disturbance that would be expected in an active excavation site, and will not interfere with subsequent soil-remediation technologies or increase waste volumes. There are many commercially available products that are effective dust-control agents. However, each of these has distinct disadvantages to their use in an active remediation environment. The primary disadvantage of most of the products is that they are difficult to remove from the soll before or during a soil-remediation process such as soil washing. This would result in a decrease in the waste reduction efficiency of the remediation technique and could lead to additional waste forms or volumes. Other potential disadvantages of various dust-control agents include the presence of potentially hazardous materials, interference with monitoring equipment, and 1 imited effective duration for some of the common dust-suppression methods.

The use of natural polysaccharides was explored as an alternative to currently available dust-control agents. Natural polysaccharides offer considerable promise for dust control in remediation settings because they are environmentally benign, they can form stable crusts or matrices on the soil surface, and they are relatively easy to remove from the soll during subsequent remediation. The primary disadvantages of natural polysaccharides compared to many commercially available products are that they do not last as long as many of the other products, and they are not as resistant to rainfall. Depending on the specific situation, these disadvantages may be inconsequential, because the applied product may be removed during the excavation process long before weathering degrades the crust integrity. Resistance to rainfall may not be important in many situations because dust generation is usually not a problem during rain storms, or rain would not be encountered if a containment structure is present over the excavation.

Two natural polysaccharides were selected for evaluation, a pregelled potato starch and XDCA, a mixed carbohydrate solution derived from sugar beets. Each of these products showed strong potential as dust-control and soil-fixative agents, and each appeared to be particularly useful in different specific situations. The evaluations consisted of a combination of field trials, laboratory physical property analyses, and wind-tunnel evaluations.

\subsection{EVALUATION OF POTATO STARCH}

Field trials at the INEL cold-test pit indicated that the potato starch performed well in stabilizing steep dig faces, and in reducing dust generation during active waste retrieval. Wind-tunnel evaluations showed that the potato starch imparts a significant amount of erosion protection to the silty INEL soil. Laboratory analyses indicated that the starch was fairly easy to remove both from the INEL soil and the Hanford Site sandy soil. In neither case was a significant decrease in soil-washing efficiency predicted. The potato 
WHC-EP-0688

starch did not impart a significant amount of erosion protection to the Hanford Site sandy soll under the highly erosive conditions in the wind-tunnel tests.

There are two primary disadvantages associated with the use of the potato starch. The first is the difficulty in preparing large quantities of solution. The preparation either requires the use of a high-speed blender, or the product must be added slowly to water while continuousiy agitating. This could be solved by modifying or adapting equipment from the food service or chemical industries. The second disadvantage is that the brittle starch crust is easily broken by foot traffic. However, the wind-tunnel tests indicate that, at least for the INEL so11, the starch crust provides significant erosion protection even when disturbed.

The potato starch appears to be most useful for relatively short-term dig-face or steep-slope stabilization during the excavation process. In this capacity the potato starch outperformed the dust-suppressant foam selected for use with the CCU. The brittleness of the starch crust would not be a serious problem on a dig face because there would be little, if any, foot or vehicular traffic on that type of surface.

\subsection{EVALUATION OF XDCA}

The XOCA sugar beet byproduct appears to be most useful for general dust suppression in situations where the treated soil will be subjected to subsequent remediation processes. The XOCA performed adequately at the INEL cold-test pit, but for the general dust-control needs of that test area, the calcium lignosulfonate was a superior material.

The XDCA provided an outstanding degree of erosion protection to the Hanford Site sandy soll and was easy to remove from the Hanford Site soil. The XDCA was not as easy to remove from the INEL soll as the potato starch, the XDCA and could cause a slight reduction in soil-washing efficiency of the INEL soil. XDCA did not appear to provide erosion protection to INEL soll. However, the stresses imparted during the wind-tunnel tests were larger than normally encountered in the field, so the XDCA would provide adequate dust control during periods of normal winds. The same would be true of the potato starch on the Hanford Site soll.

\subsection{TECHNGLOGY TRANSFER}

Both of the natural polysaccharide products are available for transfer to the private sector or to other DOE facilities for use during buried-waste retrieval and soil excavation. XDCA will be used as an overnight and overweekend soll crusting agent during the 100 Area Excavation Treatability Test planned for September 1993. This product will be applied to the contaminated soil areas at the end of each day of the excavation. The contaminated soils are expected to be soil washed at some future date. 
WHC-EP-0688

Aside from its utility in dig-face stabilization, the potato starch may be used as a binding agent during laser ablation. It may al so prove useful for fixing dust and contaminants during other decontamination and decommissioning activities. 
WHC-EP-0 888

This page intentionally left blank. 


\subsection{REFERENCES}

Blermann, A., S. Sawyer, and R. Cappabianca, 1991, Evaluation of a Soll Fixative to Retard Particle Entrainment: A Laboratory Study, UCRL-LR-109806, Lawrence Livermore National Laboratory, University of California, Livermore, California.

Clean Air Act, 42 USC 7401 et seq.

Ligotke, M.W., 1993, Soil Erosion Rates Caused by Wind and Saltating Sand Stresses in a Wind Tunnel, PNL-8478, Pacific Northwest Laboratory, Richland, Washington.

Morrison, J. L. and R. E. Heard, 1993, Buried Waste Integrated Demonstration Test Objectives, EGG-WTD-10878, EG\&G Idaho, Inc., Idaho Falls, Idaho.

Teter, A. C., 1987, Soil Fixatives Progress Report, MHSMP-87-16, Mason \& Hanger-Silas Mason Co. Inc, Amarililo, Texas.

Teter, A. C., 1988, Soll Fixative Progress Report Aerial Application Test, MHSMP-88-09, Mason \& Hanger-S11as mason Co. Amar1110, Texas.

Winberg, M. R., R. J. Pawelko, N. C. Jacobs, and D. N. Thompson, 1990, Engineering Scale Dust Control Experiments, EGG-WTD-9387, EG\&G Idaho, Inc., Idaho Falls, Idaho.

Winberg, M. R. and V. E. Wixom, 1992, Fugitive Dust Control Experiments Using Soll Fixatives on Vehicle Traffic surfaces, EGG-WTD-10354, EG\&G Idaho, Inc., Idaho Falls, Idaho. 
WHC-EP-0688

This page intentionally left blank. 
WHC-EP-0688

\section{APPENDIX A \\ WIND TUNNEL TESTS OF BIODEGRADABLE FUGITIVE DUST SUPPRESSANTS BEING CONSIDERED TO REDUCE SOIL EROSION BY WIND AT RADIOACTIVE WASTE CONSTRUCTION SITES}




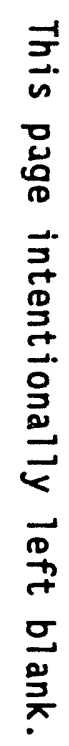


PNL-8867

UC-702

A Report Prepared for Westinghouse Hanford Company

WIND TUNNEL TESTS OF BIODEGRADABLE FUGITIVE DUST SUPPRESSANTS BEING CONSIDERED TO REDUCE SOIL EROSION BY WIND AT

RADIOACTIVE WASTE CONSTRUCTION SITES

M.W. Ligotke

G.W. Dennis

L.L. Bushaw

October 1993

Prepared for

the U.S. Department of Energy

under Contract DE-AC06-76RLO 1830

Pacific Northwest Laboratory

Richland, Washington 99352 


\section{SUMMARY}

Wind tunnel tests were performed of three fugitive dust control agents derived from potato and sugar beet products. These materials are being considered for use as dust suppressants to reduce the potential for transport of radioactive materials by wind from radioactive waste construction and remediation sites. Soil and dust control agent type, solution concentrations, application quantities, aging (or drying) conditions, surface disturbance, and wind and saltating sand eolian erosive stresses were selected and controlled to simulate application and exposure of excavated soil surfaces in the field. A description of the tests, results, conclusions, and recommendations are presented in this report.

The dust control agents included powdered potato starch, XDCA (a liquid mixture of water, sugar beet extract sugars, and organic and inorganic additives), and FPW (a fermented potato waste sludge containing starch and sugars converted by fermentation to ammonium lactate). The materials were mixed with water and spray-applied to uncompacted bare soil surfaces. The two types of soils tested were a loamy soil from Idaho National Engineering Laboratory (INEL) and a sandy soil from the Hanford Site. The surfaces were aged under controlled conditions and then exposed to increasing wind and saltating erosive stresses. Following initial tests the surfaces were disturbed, or broken, and the tests were continued to provide additional information. Data were compared to control surfaces that were subjected to similar tests. Aging conditions included a standard diurnal cycle and ultra violet- and moisture-cycling to represent possible field conditions.

The wind tunnel tests provided data for comparing the effectiveness of three fugitive dust suppressant agents. Soil type had a large impact on the effectiveness of the dust control agents. Potato starch (PS) solutions, especially the high starch, low water mixtures, such as $2.5 \%$ starch applied at $1 \mathrm{~L} / \mathrm{m}^{2}$, provided the best protection of loamy Idaho soil surfaces. Erosion rates from Idaho soil surfaces protected by potato starch were only 0 to $14 \%$ of those from control surfaces. The XDCA did not protect the Idaho soil with the marginal exception of the 33\% solution applied at $9.2 \mathrm{~L} / \mathrm{m}^{2}$. FPW provided intermediate results. In contrast, XDCA provided nearly ideal protection of the sandy Hanford soil surfaces and potato starch did not. Again, FPW provided iniermediate results. Erosion rates of XDCA-protected Hanford soil surfaces never exceeded and were generally much less than $5 \%$ of those from corresponding controls.

Tests of aging processes performed using Idaho soil showed that added moisture the erosion control effectiveness of potato starch and FPW. The XDCA-protected surfaces were not significantly impacted. The uv-cycling did not appear to impact any of the agents. The impact of biological activity was not tested. 
The results of this study indicate that all three dust control agents can protect exposed soil surfaces from extreme eolian stresses. It is also clear that the interaction and performance of each agent with various soil types may differ dramatically. Thus, soils similar to that received from INEL should be best protested by high concentration $(\sim 2.5 \%)$ solutions of potato starch at low water application levels $\left(\sim 1\right.$ to $\left.2 \mathrm{~L} / \mathrm{m}^{2}\right)$. Because the effectiveness of PS on this soil type is degraded after a moderate amount of simulated rainfall, other options or additives should be considered if surfaces are to be protected for long intervals or during periods of intermittent rainfall and hot, windy conditions. On the other hand, XDCA should be considered when excavating sandy soils. It should be noted, however, that because the Hanford soil test results are based on a small number of tests, it would be prudent to perform additional tests prior to selecting a fugitive dust control agent for use at the Hanford Site. While fermented potato waste was not the best fixative used on either soil, it did perform reasonably well on both soil types (better than XDCA on Idaho soil and better than PS on Hanford soil). Additional development work, perhaps including additives, could produce an improved product. 


\section{ACKNOWLEDGMENTS}

This work was funded through Westinghouse Hanford Company (WHC) by the U.S. Department of Energy. Materials tested during this project were obtained from a variety of sources. The powdered potato starch was supplied by Michael R. Sackschewsky, WHC. Mike was also the project manager at WHC. Robert Nachazel of Syntech Products Corporation, Toledo, Ohio, provided the XDCA product. Michael D. Brown and David E. Eakin, PNL, prepared and supplied the fermented potato waste product. Brad Loucks and Alex Work assisted in performing the wind tunnel tests. 


\section{CONTENTS}

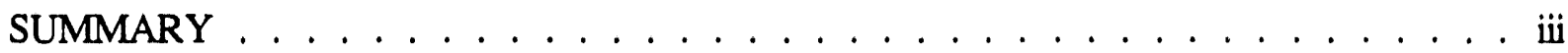

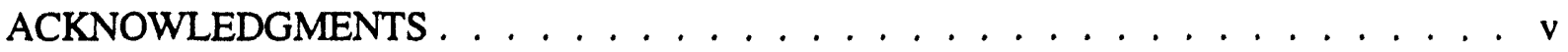

1.0 INTRODUCTION. . . . . . . . . . . . . . . . . . . A.1

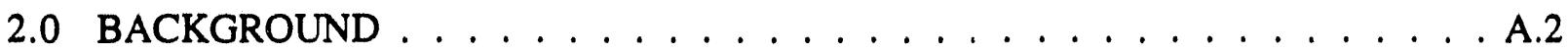

3.0 MATERIALS AND METHODS $\ldots \ldots \ldots \ldots \ldots \ldots$. . . . . . . . . . . . . . .

3.1 WIND TUNNEL TEST FACILITY $\ldots \ldots \ldots \ldots$. . . . . . . . . . A.3

3.2 WIND AND SALTATING SAND STRESSES . . . . . . . . . . . . . A.3

3.3 MATERIALS AND TEST SURFACES $\ldots \ldots \ldots \ldots$. . . . . . . . . . . . .

3.4 TEST PROCEDURES AND MEASUREMENTS $\ldots \ldots \ldots$. . . . . . . . . . . A.9

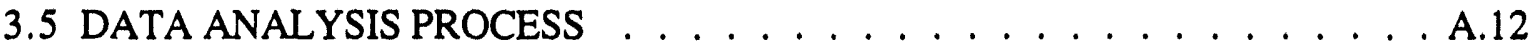

4.0 RESULTS AND DISCUSSION . . . . . . . . . . . . . . . . . . A.13

4.1 TESTS AND SURFACE CONFIGURATIONS . . . . . . . . . . . . A.13

4.2 APPLIED EOLIAN EROSIVE STRESSES . . . . . . . . . . . . . . . A.13

4.3 SURFACE DEFLATION RATE RESULTS . . . . . . . . . . . . . . . . A.16

4.3.1 Dry and Wet Control Surfaces (Not Treated) . . . . . . . . . . A.17

4.3.2 Potato Starch Surface Crusts _ . . . . . . . . . . . . . . A.21

4.3.3 XDCA Sugar Beet Extract Surface Crusts … . . . . . . . . . A.24

4.3.4 Fermented Potato Waste Surface Crusts . . . . . . . . . . . . . . . A.28

4.3.5 Impact of Soil Type on Surface Protection . . . . . . . . . . . . . A.29

5.0 CONCLUSIONS AND RECOMMENDATIONS . . . . . . . . . . . . . . . . A.39

6.0 REFERENCES . . . . . . . . . . . . . . . . . . . . . A.42

APPENDIX A-A WIND TUNNEL TEST DATA AND DEFLATION RATE

RESULTS. . . . . . . . . . . . . . . . . . . . . . A-A.1

APPENDIX A-B WIND TUNNEL TEST DATA GROUPED BY TEST

PARAMETER. . . . . . . . . . . . . . . . . . . A-B.1 


\section{EIGURES}

3.1 Orthographic Projection of the PNL Aerosol Wind Tunnel Research Facility. . . . . . A.4

4.1 Deflation Rate from Dry Control Soil Surfaces Versus Mean Wind Speed. . . . . . . A.18

4.2 Deflation Rate From Undisturbed Dry Control Soil Surfaces. . . . . . . . . . . . . A.18

4.3 Deflation Rate from Undisturbed Wet Control Soil Surfaces . . . . . . . . . . . . . A.19

4.4 Deflation Rate from Undisturbed Idaho Soil Wet Control Surfaces . . . . . . . . . . A.19

4.5 Deflation Rate from Disturbed Idaho Soil Wet Control Surfaces . . . . . . . . . . . A.20

4.6 Deflation Rate from Undisturbed Idaho Soil Protected by Potato Starch. . . . . . . . A.22

4.7 Deflation Rate from Disturbed Idaho Soil Protected by Potato Starch . . . . . . . . . A.22

4.8 Influence of Aging Conditions on Undisturbed Potato Starch Crusts . . . . . . . . . A.23

4.9 Influence of Aging Conditions on Disturbed Potato Starch Crusts . . . . . . . . . . A.23

4.10 Undisturbed Idaho Soil Protected by XDCA - Application Quantity Tests. . . . . . . A.25

4.11 Disturbed Idaho Soil Protected by XDCA - Application Quantity Tests . . . . . . . . A.25

4.12 Undisturbed Idaho Soil Protected by XDCA - Solution Concentration Tests . . . . . A.26

4.13 Disturbed Idaho Soil Protected by XDCA - Solution Concentration Tests . . . . . . . A.26

4.14 Influence of Aging Conditions on Undisturbed XDCA Crusts . . . . . . . . . . . . A.27

4.15 Influence of Aging Conditions on Disturbed XDCA Crusts . . . . . . . . . . . . . A.27

4.16 Undisturbed Idaho Soil Protected by FPW - Application Quantity Tests . . . . . . . A.30

4.17 Disturbed Idaho Soil Protected by FPW - Application Quantity Tests . . . . . . . . . A.30

4.18 Undisturbed Idaho Soil Protected by FPW - Solution Concentration Tests . . . . . . A.31

4.19 Disturbed Idaho Soil Protected by FPW - Solution Concentration Tests. . . . . . . . A.31

4.20 Influence of Aging Conditions on Undisturbed FPW Crusts . . . . . . . . . . . . . A.32

4.21 Influence of Aging Conditions on Disturbed FPW Crusts . . . . . . . . . . . . . . A.32

4.22 Surface Deflation Rates Measured from Undisturbed (Wind and Saltating Sand) Idaho and Hanford Soils Protected by PS, XDCA, and FPW Dust Control Agents . . A.34

4.23 Surface Deflation Rates Measured from Disturbed (Wind Only) Idaho and Hanford Soils Protected by PS, XDCA, and FPW Dust Control Agents. . . . . . . . . . . A.35

4.24 Surface Deflation Rates Measured from Disturbed (Wind and Saltating Sand) Idaho and Hanford Soils Protected by PS, XDCA, and FPW Dust Control Agents . . . . . A.36 


\section{TABLES}

4.1 Fugitive Dust Control Surface Fixative Agent Tests Performed in a Wind Tunnel Between March and August 1993 . . . . . . . . . . . . . . . . . . . . A.14

4.2 Ratio of Deflation Rates--Potato Starch Agent-Protected to Wet Control Surfaces, Idaho Soil Only. . . . . . . . . . . . . . . . . . A.24

4.3 Ratio of Deflation Rates--XDCA Agent-Protected to Wet Control Surfaces, Idaho Soil Only. . . . . . . . . . . . . . . . . . . . . . . A.28

4.4 Ratio of Deflation Rates--FPW Agent-Protected to Wet Control Surfaces . . . . . . . A.33

4.5 Ratio of Deflation Rates --Agent-Protected to Wet Control Surfaces . . . . . . . . . A.38 


\subsection{INTRODUCTION}

Effective, inexpensive, environmentally safe methods are being sought to control wind transport of contaminated soil from excavation related to clean up of radioactive waste sites. Initial work has focused on agricultural waste or related products containing natural polysaccharides such as starch and pectin. In support of this work, the Pacific Northwest Laboratory (PNL)(a) contracted with Westinghouse Hanford Company (WHC) to perform wind tunnel tests of the relative effectiveness of two dust suppressant agents to protect bare soil surfaces. Tests of an additional dust control agent were supported by PNL and are included in this report. The WHC project, "Contaminant Migration Control: Fixation of Soil Surface Contamination Using Natural Polysaccharides" was created to support a U.S. Department of Energy Integrated Field Demonstration Project at the Idaho National Engineering Laboratory (INEL).

Staff at the PNL Aerosol Wind Tunnel Research Facility performed 69 tests of three dust control agents derived from potato and sugar beet products. Soil and dust control agent type, solution concentrations, application quantities, aging (or drying) conditions, and wind and saltating sand eolian erosive stresses were selected and controlled to simulate application and exposure of excavated soil surfaces in the field. All surfaces were dried under diurnal conditions prior to testing. Surface treatments that survived a series of four wind tunnel tests of incrementally increasing wind and saltating sand erosive intensity were then disturbed in a uniform, repeatable manner, and the four tests were repeated to provide information on the ability of the dust control agents to continue to protect the surface after being broken. Data were compared to dry and wet control surfaces that were subjected to similar tests. Solution concentrations (percentage of agent mixed with water) and application quantities (volume of total solution applied per surface area) were tested over ranges under consideration for use in the field. Aging conditions included a standard diurnal cycle and ultraviolet- (uv) and moisture-cycling to represent possible actual field conditions.

This report includes a description of the tests, a discussion of results, and a statement of conclusions and recommendations. Actual test data and summaries grouped by test parameters are provided in the appendices. This project was performed to test the effectiveness of agents to control fugitive dust emissions only; no cost comparisons or other field-scale logistical issues were considered.

(a) Operated by Battelle Memorial Institute for the U.S. Department of Energy under Contract DE-AC06-76RLO 1830. 


\subsection{BACKGROUND}

Construction activities associated with reclamation of radioactive waste sites have the potential for creating fugitive dust sources. Surface fixatives are needed to prevent contamination from leaving the site. Copious amounts of water, such as supplied by in-place irrigation systems, might not provide the best solution because any drainage could increase the transfer of radioactive materials into the groundwater at waste sites. Therefore, the use of natural, biodegradable fugitive dust suppressant agents (surface fixatives) could provide the best solution for mitigating risks associated with fugitive dust emissions from clean-up sites.

The stability of soil surfaces subject to erosive stresses in an arid environment depends on their protection by non-erodible elements or crusts. Surfaces that are armored by crusts or gravel or protected by vegetation have greater resistance to eolian erosion. In addition, the formation of soil aggregates also aid surface stability. In contrast, sand-sized materials in the surface layer can act as an abrasive agent and reduce its resistance to eolian stresses. Freshly disturbed surfaces are the most susceptible to transport offsite by wind. Surface crusts, whether formed by water or applied fixatives improve the resistance of surfaces to eolian stresses. Water crusts form as soluble materials in the soil are dissolved and concentrate at the surface. They are often brittle and provide only brief protection. Surface fixatives are designed to provide additional protection by containing dissolved, particulate, or fibrous elements that, upon drying, enhance the natural water crust.

After drying, erosive processes begin to act to degrade protective crusts. Wind gusts provide the driving force for erosion of exposed soil surfaces and their subsequent transport away from a site. Wind also acts to transport sand, where present on the surface or mixed in native soils, across the surface in abrasive saltation that results in the reduction of natural or applied surface protection. At arid sites, surface and climatic conditions combine to produce low-moisture soils that are especially susceptible to erosion when disturbed. Mechanisms of eolian erosion include surface creep, saltation, and suspension. Surface creep is the wind-driven sliding and rolling of sand and soil particle aggregates along the surface. Saltation is the transport mechanism of sand-sized particles and consists of vertical leaps followed by low-angle returns to the surface. Suspension is the long-distance transport of soil particles away from exposed surfaces. Saltation, and to a lesser extent creep, are often the primary causative mechanisms of soil erosion in arid lands; the kinetic energy of windborne or rolling grains is imparted to dry surfaces on impact and causes crust abrasion, soil particle suspension, and surface deflation. 


\subsection{MATERIALS AND METHODS}

Solutions of three candidate fugitive dust suppressant agents were prepared, applied to flat unpacked soil surfaces, and exposed to ranges of wind and saltating sand erosive stresses under controlled conditions in a wind tunnel. The tests were performed in a wind tunnel to allow known surface treatments to be compared by exposure to controlled and similar erosive stresses. Erosive stresses were selected to represent extreme conditions anticipated in the field. Materials, the preparation and handling of test surfaces, procedures, and test data were documented and are reported in this section.

\subsection{WIND TUNNEL TEST FACחITY}

Tests were conducted at the PNL Aerosol Wind Tunnel Research Facility. The facility, shown in Figure 3.1, is located on the Hanford Site in southeastern Washington. The facility's environmental wind tunnel is equipped to control wind speed, temperature, humidity, and lighting. Heat generated during high-speed tests is dissipated using an integrated air conditioning system. Wind speed profiles and boundary layers are uniform and controlled within the $0.61-\mathrm{m}$ square by $6.1-\mathrm{m}$ long test section that was used for the wind erosion tests. The maximum attainable wind speed in the test section is $36 \mathrm{~m} / \mathrm{s}(80 \mathrm{mph})$. Greater wind speeds may be achieved by reducing the cross-sectional area of the test section. Wind speed and other environmental data are recorded using a computerized data acquisition system. Two exhaust systems that use filters and scrubbers maintain the wind tunnel at slightly reduced air pressure during tests to contain dust, chemicals, or other test materials.

\subsection{WIND AND SALTATING SAND STRESSES}

Comparison of fugitive dust suppressant agents requires that realistic maximum stresses be applied to test surfaces. These must be repeatable to ensure that test-to-test variations are limited to parameters of interest such as fixative type, concentration, application rate, weathering, etc. Wind and saltating sand grains were applied to test surfaces to simulate worst-case natural conditions and identify which surface application methods provided the best surface protection.

Wind and saltating sand erosive stresses were applied based on previously completed work supporting the development of a gravel admixture in silt-loam soil to reduce rates of erosion by wind (Ligotke 1993). Peak wind gust data at Hanford and wind tunnel air-flow boundary layer conditions were considered to determine wind tunnel air velocities needed for the tests. The peak wind gust (PG) retum period (RP) for the Hanford Site Meteorological Station, based on Stone et 


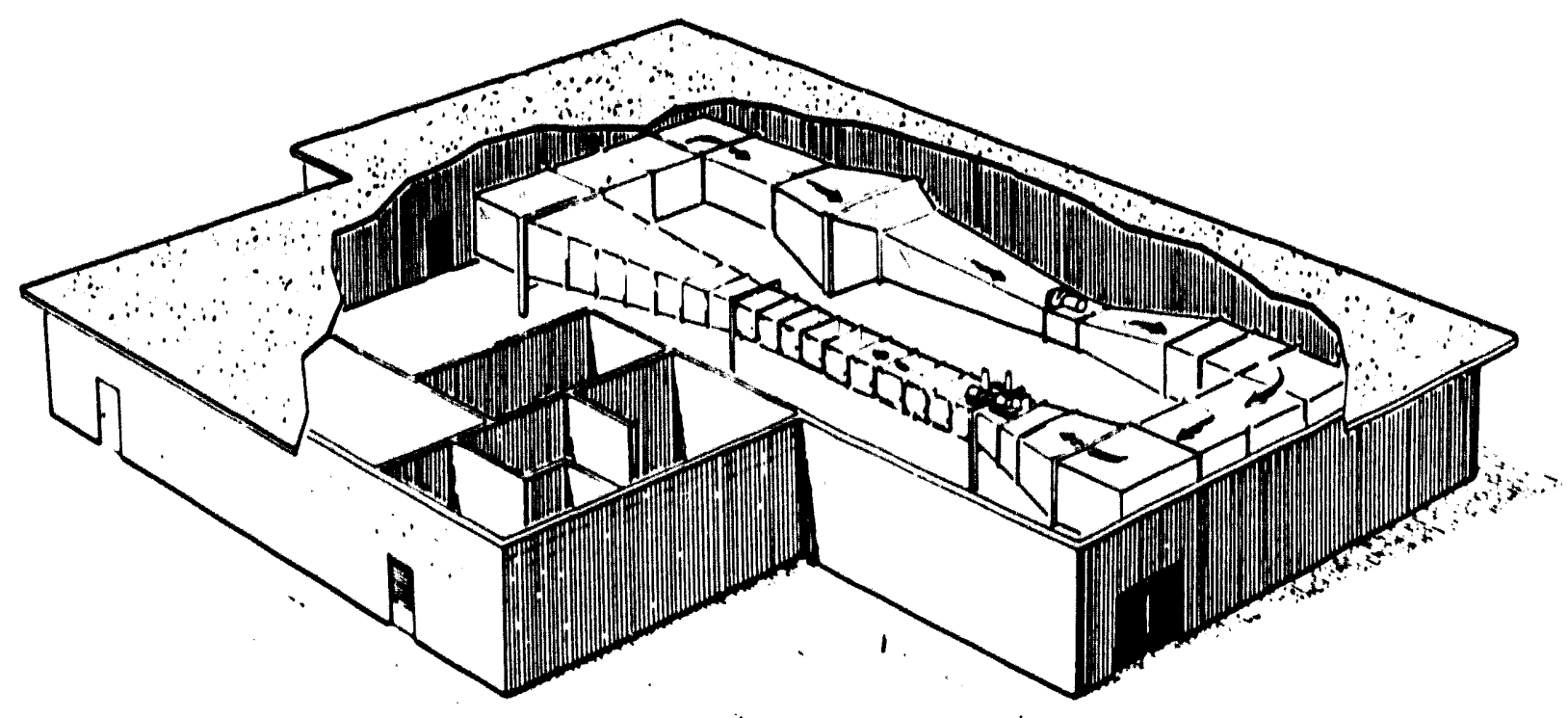

ElGURE 3.1. Orthographic Projection of the PNL Aerosol Wind Tunnel Research Facility

al. (1983) and excluding data having return periods of less than 2 years, was found to be represented by:

$$
P G=26.05+2.348 * \ln (R P) \quad R^{2}=0.965
$$

Thus, peak gusts of 31.5 and $37 \mathrm{~m} / \mathrm{s}$ ( 70 and $82 \mathrm{mph}$ ) may be expected to have return periods of 10 and 100 years, respectively. Based on this information, and the determination by Ligotke and Klopfer (1990) that the ratio of wind speed at $2 \mathrm{~m}$ to that at $15 \mathrm{~m}$ was approximately $1.5 \pm 0.2$, the corresponding peak gusts at the lower height would be $21 \pm 3$ and $25 \pm 4 \mathrm{~m} / \mathrm{s}$, respectively.

Ligotke (1993) provided an evaluation of surface shear stresses produced in a wind tunnel compared to those produced in the field at Hanford. Because of thicker air-flow boundary layers present in the field, comparable shear stresses are produced at lower wind speeds in a wind tunnel. This does not reduce the validity of wind tunnel data, but rather, underlines the importance of using surface shear stress (or friction velocity) rather than wind speed when comparing wind tunnel data with actual field conditions. 
Eolian erosive forces are created by the flow of air over surfaces and may be modeled physically in wind tunnels. Rather than measuring it mechanically, the shear stress may be calculated from measurements of the change in wind speed with elevation near to the surface. Therefore, by measuring the air-flow boundary layer over the surface it is possible to determine surface shear stress. Two parameters that are useful in the determination of surface shear stress are roughness height $\left(z_{0}\right)$ and friction velocity $\left(u^{*}\right)$. Friction velocity is an erosion parameter that is related to surface shear stress by:

$$
u^{*}=\left(\tau_{s} / \rho_{0}\right)^{1 / 2}
$$

where $\tau_{s}$ is the surface shear stress (force/erea) and $\rho_{o}$ is the density of air (mass/volume). Solving the equation results in units of length/time for $u^{*}$, and hence, the name "friction velocity." At constant temperature, $u^{*}$ increases as the square root of increasing $\tau_{s}$. Another erosion parameter influencing the interaction between wind and surface is the roughness height. The parameter $z_{0}$ is a measure of the aerodynamic roughness of a particular surface, and thus, its capacity to impart aerodynamic drag on air flowing over it. It is influenced by, but not equal to, the average or maximum height of surface roughness elements such as gravel, tilled ridges, or vegetation. Roughness heights are also measured as a function of the air-flow boundary layer, and are often between $1 / 10$ and $1 / 30$ of the apparent average height of surface relief.

Calculating $z_{0}$ and $u^{*}$ from measured air-flow boundary layers provides a quantitative method of comparing different surfaces and surfaces shear stresses, respectively. Vertical air-flow boundary layers over rough surfaces take the form

$$
\Delta u=\left(u^{*} / k\right) \ln \left(z_{1} / z_{2}\right)
$$

where $u$ is mean air velocity, $z$ is elevation, and $k$ is the Von Karmon constant $(0.40)$. In the equation, $u$ and $z$ are measured at two elevations, 1 and 2 , above the surface, and $\Delta u=u_{1}-u_{2}$. By plotting measured boundary layers as the local mean wind speed versus the natural log of dimensionless elevation, both aerodynamic surface roughness $z_{0}$ and friction velocity $u^{*}$ can be determined. Such plots are reduced linearly over the elevation range of the air-flow boundary layers and take the linear form

$$
\ln \left(\mathrm{z}_{\mathrm{d}}\right)=\mathrm{b}+\mathrm{M}\left(\mathrm{u}_{\mathrm{z}}\right)
$$

where $z_{d}=$ the dimensionless elevation

$\mathrm{u}_{\mathrm{z}}=$ the local velocity at elevation $\mathrm{z}$

$\mathrm{b}=$ the elevation axis intercept

$M=$ the slope of the curve fit $(M=\Delta z / \Delta u)$. 
Both surface shear stress parameters can be determined using Equations (3.3) and (3.4). The parameter $z_{0}$ is defined using Equation (3.4) as the elevation above the surface at which the mean air velocity is zero. Rather than being a quiescent region, however, the $z_{0}$ elevation is a region where air velocities occur but fluctuate in direction and average zero. Therefore, $\mathrm{z}_{0}$ occurs at the extrapolated elevation axis intercept. For example, an intercept of -3.00 corresponds to a $z_{0}$ of $0.050 \mathrm{~cm}$. The parameter $\mathrm{u}^{*}$ is determined from Equation (3.3) as

$$
u^{*}=k \Delta u / \ln \left(z_{1} / z_{2}\right)=k M \cdot 1
$$

where $M$ equals $\ln \left(z_{1} / z_{2}\right) / \Delta u$ and $u^{*}$ has units of $u$. For an air-flow boundary layer having $\mathrm{M}=0.30$, the corresponding $\mathrm{u}^{*}$ is $1.33 \mathrm{~m} / \mathrm{s}$. At wind speeds less than those that modify or smooth a surface (as a strong wind smoothes a grassy field), $z_{0}$ is constant, and $u^{*}$ increases linearly with wind speed.

The range of wind speeds selected for the current project was based on those used in a previous study. Because of uncertainties associated with the determination of stresses present in the field, it is likely that the selected wind speeds are representative of many arid locations in the west. The comparison of field and wind tunnel stresses indicated that $25 \mathrm{~m} / \mathrm{s}$ is a reasonable upper limit on wind speed in wind tunnel tests (Ligotke 1993). Resulting friction velocities at wind tunnel wind speeds of 20 and $25 \mathrm{~m} / \mathrm{s}$ were estimated to be roughly 1.5 and $2 \mathrm{~m} / \mathrm{s}$, respectively, over flat surfaces.

Having selected the range of wind speeds for wind tunnel tests, the range of erosive stress caused by saltating sand particles was assigned to be equal to and less than the quantity of dune sand that could be carried by the test wind speeds. Sand was moved by wind from deposits placed on top of boundary layer surfaces 0.5 to $1.5 \mathrm{~m}$ upwind of the test surfaces. Sand particles passed across the test surfaces in saltation and creep. The intensities of sand storms simulated in the wind tunnel, based in part on the Hanford Site sand transport potentials described by Glantz et al. (1990), were 170 and $250 \mathrm{~g} /\left(\mathrm{m}^{2}-\mathrm{s}\right)$ for the 20 and $25 \mathrm{~m} / \mathrm{s}$ wind speeds.

\subsection{MATERIALS AND TEST SUREACES}

Test materials included soils, sand, water and dust suppressant agents. Two types of soils were received, a loamy soil from Idaho National Engineering Laboratory (INEL) and a sandy soil from Hanford. A few control tests were performed using McGee Ranch silt-loam soil from the batch tested by Ligotke (1993). Three batches of the Idaho soil were used. Sand was taken from an active dune on the Hanford Site. Water was mixed with dust control agents to aid application to test surfaces. Three dust control agents were used, powdered potato starch (PS), XDCA, and 
fermented potato waste (FPW). The PS was commercial grade powder obtained from WHC. The XDCA, a liquid mixture of water, sugar beet extract sugars, and organic and inorganic additives, was obtained by WHC from Syntech Products Corporation. The Syntech product was formerly known as Dust Suppressant (CMS). PNL supplied three different batches of the FPW. The FPW was prepared by fermenting potato sludge derived from off-specification product and filter belt slurry from a commercial processing plant. The material contained starch and sugars converted by fermentation to ammonium lactate. Each batch of FPW was slightly different in appearance, with the third batch seeming to be more watery with less particulate matter.

Materials were used in bulk or were sieved to obtain needed particle size distributions. Sieve numbers herein refer to U.S. Alternate classifications. The soil was stored in barrels until just prior to use. The Idaho soil was screened using 0.25 - to 0.38 -in. mesh sizes, and larger unbreakable material and clods were removed. Hanford and McGee Ranch soils were used as collected. Soil moisture content tests were not required because initial moisture content was small, and moisture levels during tests (after aging in a growth chamber) were even less and did not contribute to surface mass loss during the wind tunnel tests. Idaho soil was loamy with small particles and hard clods ranging from about $1 / 16$ to $<3 / 8$ in. (after sieving). Hanford soil was a uniform sandy silt with easily breakable clods. McGee Ranch silt loam was fine and powdery when dry with medium to hard clods. The three batches of the Idaho loamy soil appeared grossly similar; however, comparison tests were performed between Batches 1 and 2 to determine their similarity with regard to erosion.

Dune sand was collected from the Hanford Site during both dry and moist periods. Moisture was removed when necessary using a drying oven or a growth chamber. The dry sand was sifted through a No. 18 sieve and stored in a sealed barrel. The grain size distribution of sand was measured using Method D422-63 (ASTM 1984), modified by the use of additional intermediate sieves to provide finer particle size gradation. The mass median grain size was 0.020 $\mathrm{cm}$. The geometric standard deviation of the distribution was 1.65. Sand grains well represented the range susceptible to transport by saltation, with $90 \%$ of the sand mass consisting of grains having diameters between 0.010 and $0.038 \mathrm{~cm}$.

Test surfaces were prepared by placing soil into stainless steel trays, leveling and smoothing the surface, and applying a surface agent. Control surfaces were prepared and left dry (dry controls) or sprayed with tap water (wet controls). The trays were square, having $50.5 \mathrm{~cm}$ wide sides, a surface area of $0.255 \mathrm{~m}^{2}$, and depth of $1.9 \mathrm{~cm}$. Soil surfaces were prepared to a total height of $3.2 \mathrm{~cm}--1.3 \mathrm{~cm}$ above the rim of the tray. A few early tests, identified in Section 4.0, were performed with total surface heights of $2.9 \mathrm{~cm}$. Trays were prepared with $9300 \mathrm{~g}$ of Idaho 
soil or $9500 \mathrm{~g}$ of Hanford soil in an attempt to maintain uniform densities for all surfaces of each type. After placing the soil and smoothing the surface, all four edges were packed back at an angle of roughly $45^{\circ}$ to prevent sloughing losses. Tray masses, less tare weights, were recorded.

Guidance was provided by WHC, PNL, and Syntech regarding the concentrations and application quantities to be applied for each dust control agent. The test matrix for each agent was modified slightly based on the results of early tests to ensure that an appropriate range of conditions was tested. These mid-project decisions were made based on performance and not costbenefit considerations. The PS was prepared by mixing 1.0 and $2.5 \%$ solutions and applying a nominal solution volume of 0.25 to $1.0 \mathrm{~L}$ to test surfaces. The solutions were prepared as mass per volume, with a $1.0 \%$ solution consisting of $1.00 \mathrm{~g}$ of PS per $100 \mathrm{~mL}$ of water. Because PS did not readily mix with water, a blender was used at high and low speed for several minutes. The resulting solution was fairly stable over a period exceeding $10 \mathrm{~min}$, with only a small quantity of PS settling to the bottom of a container. Spray applications of PS provided both the liquid and suspended solids constituents of the solution to test surfaces. The XDCA was easily mixed with water and was spray-applied to surfaces. Liquid XDCA had an undiluted density of $1.26 \mathrm{~g} / \mathrm{cm}^{3}$ and was mixed with water volumetrically at $1: 2$ and 1:1 concentrations (see Section 4.1). The FPW was shaken vigorously and mixed volumetrically at 1:1 through 1:9 (see Section 4.1) with water and applied using a "watering can" method. This method was used because the size of solids in the solution precluded use of the spray nozzle. The method consisted of shaking the FPW solutions in an inverted container having an array of twelve $0.16 \mathrm{~cm}$ holes drilled into its lid. While the solids in the FPW solutions plugged the fine nozzles needed for the small areas tested in the wind tunnel, it is expected that these solids will not cause difficulties in the field because of greater volumetric application rates.

The amount of water or agent solution applied to each surface was tracked using either gravimetric or volumetric methods, or both. In all cases, surfaces were also weighed before and after application. Differences between the amounts measured to have been added to the surfaces and those applied were caused primarily by loss of small amounts around the tray edges and to a lesser extent by evaporation. The actual quantity applied was determined from the mass change of the surface. Except for applications of less than $0.5 \mathrm{~L}$, two half applications were made to each tray to ensure complete and uniform coverage. Application quantities generally refer to nominal values. Applications were made uniformly over the surfaces with the exception that perhaps twice the nominal application rate was applied to an approximately $2 \mathrm{~cm}$ wide perimeter edge of the surface. This was done to reduce the susceptibility of the edge regions to erosion. 
Surfaces were aged following application of fugitive dust control agents to allow the added moisture to dry. This was done to represent actual field conditions and to remove the varying levels of moisture from the test surfaces. Moisture added ranged from 0.25 to $2.34 \mathrm{~L}$ per tray. An aging period of 4 days generally reduced the moisture to standard levels (determined by gross tray mass). An alternate drying period of 5 days was used for surfaces having the $2.34 \mathrm{~L}$ application (this application was only performed for XDCA). All aging took place in a plant growth chamber having a diumal cycle of $40^{\circ} \mathrm{C}$ during 12 -h days, and $20^{\circ} \mathrm{C}$ during 10 -h nights. Two 1 -h transition periods of light and temperature (dawn and dusk) also occurred each day. Selected surfaces were exposed to uv radiation during the daylight cycles of the 4 days between preparation and testing. Four Sylvania 350 Blacklight 20-W lamps were suspended $44 \mathrm{~cm}$ above the surfaces to provide the uv source. Other selected surfaces were exposed to simulated rain three times during an extended drying period. After three days of normal aging, these surfaces were sprayed lightly with a total of $0.5 \mathrm{~L}$ of water per tray for each of the next three days. The surfaces were then allowed to dry normally for four days after the third application of water.

\subsection{TEST PROCEDURES AND MEASUREMENTS}

Tests were conducted between March and August 1993. Test procedures were modifications based on those reported by Ligotke and Klopfer (1990) and Ligotke (1993). Surfaces were exposed to known wind-caused surface shear stresses through a series of up to eight subtests. Surface masses (surface and tray masses) were recorded before each test and between subtests, and mass changes were used to determine deflation rates. Surfaces were tested undisturbed then disturbed until the subtest series was complete or failure criteria were met. Observed test conditions were recorded on the back of data sheets. Because several seconds were required to attain the target wind speed at the beginning of each subtest, the wind tunnel fan controller was engaged approximately $8 \mathrm{~s}$ prior to the planned start of each subtest. The impact of this uncertainty on the duration of subtests was about $6 \mathrm{~s}$ (about $5 \%$ of a 2 -min subtest).

The test section of the wind tunnel was configured to provide steady air-flow boundary layers to test surfaces. Three boundary layer surfaces, extending over a length of $152 \mathrm{~cm}$, were positioned upwind of one test tray. The boundary layer surfaces consisted of weathered $0.67-\mathrm{cm}$ pea gravel admixtures surfaces that modified air-flow boundary layers by providing frictional drag. The surfaces were prevented from eroding by the protection of a thin layer of water-soluble polyvinyl alcohol that was sprayed on wet and allowed to dry. Aluminum angle studded with pea gravel was placed to the sides of the boundary layer and test surfaces to extend the width of the rough surface and reduce preferential scouring along the edges of test surfaces. The elevation of the test surface was maintained near that of the boundary layer surfaces using shims. The wind 
tunnel was operated with dust-stop filters placed in the $4.5-\mathrm{m}^{2}$ cross-section return loop to trap suspended soil. An air conditioner removed heat generated when operating the wind tunnel at high speed for extended periods.

Surfaces were exposed to as many as eight subtests. Subtests 1 through 4 proceeded from target wind speeds of $20 \mathrm{~m} / \mathrm{s}, 25 \mathrm{~m} / \mathrm{s}, 20 \mathrm{~m} / \mathrm{s}$ plus $10 \mathrm{~kg}$ of sand, and $25 \mathrm{~m} / \mathrm{s}$ plus $15 \mathrm{~kg}$ of sand. After Subtest 4, surfaces that had not failed (see below) were disturbed to break up the crust. Effort was made to break the surface crusts in a similar fashion from test to test. A regular grid of square-edged indentations were pressed into the surfaces using a plexiglass tool having an array of teeth $1.2 \mathrm{~cm}$ square and $0.7 \mathrm{~cm}$ deep. These indentations were separated by a distance of $2.5 \mathrm{~cm}$. The tool was used to press a single row of 19 indentations into each surface near its leading edge, and then lifted above the surface and moved to make a total of 19 rows of indentations transverse to the direction of wind. After disturbing the surface, a new mass was recorded, and Subtests 5 through 8 were performed. This second series of subtests repeated the conditions of Subtests 1 through 4. Tests were performed for a duration of $2 \mathrm{~min}$, with a few exceptions. Dry control surfaces were exposed to 10 and $15 \mathrm{~m} / \mathrm{s}$ for durations of 5 minutes, followed by the normal test process until failure. Wet control surfaces were subjected to the same test series as were agentcoated surfaces.

Surface crusts either survived the entire eight-part test or failed during the process. Because of an inability to match the test surface to the boundary layer surface after all material above the test tray rim had been eroded, tests were considered to be complete, or the surfaces to have failed, after a portion of the tray rim became exposed. Failure often occurred at the back rim because of the greater influence of creep and saltation on the downwind portions of the test surface. At other times, surfaces failed when a large fraction of the surface crust had been removed, leaving unprotected material exposed to wind. The mass of the test trays were measured before and after each subtest by removing the trays from the wind tunnel and placing them on a mass balance. Test surfaces having an accumulated mass loss of about $2000 \mathrm{~g}$ were also considered to have failed. Replicate tests were performed on all fixative application rates with the exception of two FPW tests that did not perform well. Subtests completed after failure criteria were met were not included in the final analysis of data. Subtests completed on replicate trays after another replicate surface failed were not included either.

Measurements were required during each test to characterize surface characteristics, environmental conditions, erosive stresses, and surface deflation mass losses. Measurement devices were compared to laboratory standards when needed. Others were based on standard 
quality assurance certifications. In addition, photographs were taken to document changing surface conditions during selected tests.

Trays were weighed every day after preparation to note mass changes. By the fourth day, most added moisture was depleted. Trays were removed from the growth chamber and allowed to come to room temperature before testing. Mass was recorded just prior to beginning each test. Changes in mass of test surfaces exposed to wind and sand erosive stresses were monitored by removing the surfaces after each subtest and measuring their mass using a Sartorius Model 3807 high-capacity mass balance. The device was readable and accurate to $\pm 1 \mathrm{~g}$. Other uses of the Sartorius balance included weighing solutions and surfaces during application of dust control agents and preparing 10 and $15 \mathrm{~kg}$ quantities of sand for the saltation tests. A Mettler PE 163 mass balance with an accuracy better than $\pm 0.01 \mathrm{~g}$ was also used in the preparation of solutions. Mass balances were calibrated routinely by the Hanford Westinghouse Standards Laboratory.

Mean wind speed, temperature, and relative humidity were measured routinely using the facility's computer data acquisition system. Temperature and relative humidity were measured using a General Eastern Model 1500 hygrocomputer. The device was supplied by the manufacturer with a calibration certificate and checked using a constant-draft psychrometer prior to being used to monitor wind tunnel conditions. Mean wind speed was measured using a pitot-static probe located at the center of the test section and oriented within less than $5^{\circ}$ of the mean wind direction. The probe was located in a region of uniform flow well away from the influence of airflow boundary layers. The pitot-static probe provided dynamic and static pressures to a Model 398 MKS Baratron differential pressure transducer connected to a Model 270B controller and the facility computer system. The MKS system measured the pressure difference between the static and dynamic pressures in the wind tunnel test section. The computer system was used to convert these data to wind speed and store the information. Mean wind speed, $\mathrm{u}$ in $\mathrm{m} / \mathrm{s}$, was determined by measuring the pressure differential, $\Delta \mathrm{p}$ in in.- $\mathrm{H}_{2} \mathrm{O}$, and the air temperature and pressure, $\mathrm{T}$ and $\mathrm{P}$ in ${ }^{\circ} \mathrm{K}$ and in.-Hg, respectively. Wind speed was calculated using the Bernoulli equation reduced to the form

$$
\mathrm{u}=6.496(\mathrm{~T} / \mathrm{P})^{1 / 2}(\Delta \mathrm{p})^{1 / 2}
$$

Wind speed calibrations were performed by comparing the output of the MKS system to a Dwyer Model 1430 micromanometer with a certified micrometer. No adjustments to the factory calibration of the MKS system were required as both it and the Dwyer generally agreed within about $1 \%$. The standard deviations of the typically five measurements made during each subtest were generally less than $1 \%$ of the mean wind speeds. Erosive stresses provided by wind to the test surfaces were based on boundary layer measurements made previously (Ligotke 1993). 


\subsection{DATA ANALYSIS PROCESS}

Test data were analyzed to determine surface deflation rates and effectiveness of applied dust control agents. The information was used to compile a set of data for future reference and to form correlations and make conclusions. Data included soil type, agent, agent concentration, quantity of agent applied, aging conditions, temperature, relative humidity, wind speed, surface mass history, and observations. All data for each test were recorded on two data sheets. The average, standard deviation, and number of wind speed measurements were calculated on test data sheets, and the mean wind speeds were entered directly into deflation rate data worksheets. Worksheets were used to calculate surface deflation rates from mass change, subtest duration, and surface area information. Deflation rate $\left(D_{r}\right)$, in grams per square meter per second $\left(g /\left(m^{\wedge} 2-s\right)\right)$, were calculated from subtest data as:

$$
D_{r}=\Delta M /\left(A_{s} \Delta t\right)
$$

where $\Delta \mathrm{M}$ is the loss in mass of the test surface in $\mathrm{g}, \mathrm{A}_{\mathrm{s}}$ is the surface area of the test surface in $\mathrm{m}^{2}$, and $\Delta t$ is the duration in seconds of the subtest. These data were summarized in other worksheets by subtest, agent and soil type, agent concentration, application quantity, and aging conditions. Comparisons were made of the various test parameters. Because of the range-finding nature of this study and the variability associated with the Idaho soil wet controls, results of each set of parameters were compared to others using average deflation rates and considering uncertainty to equal the standard deviation of typically two replicate tests. Significant differences between two sets of parameters were considered to have occurred when no overlap occurred in the deflation rates and their uncertainties. 


\subsection{RESULTS AND DISCUSSION}

This section, Appendix A-A, and Appendix A-B present the results of wind erosion tests performed between March and August 1993, including a list of tests and surface configurations, descriptions of applied eolian erosive stresses, and actual deflation rate results compared with test parameters. Data generated provide information regarding the influence on deflation rate (fugitive dust control) of wind speed and sand particle saltation for a range of applications of three dust control agents on two soil types.

\subsection{TESTS AND SURFACE CONFIGURATIONS}

A list of tests completed in the present study is shown in Table 4.1. As described in Section 3.0, the fugitive dust control agents were potato starch (PS), XDCA, and fermented potato waste (FPW). The PS solution concentrations refer to percentage by mass in water, $k: 1$, where $k$ grams of PS power were mixed in each $100 \mathrm{~mL}$ of water. The $1.0 \%$ PS solution is listed as 1.0:100, and the $2.5 \%$ solution as 2.5:100. The XDCA and FPW concentrations, m:n, refer to $\mathrm{m}$ parts concentrate plus n parts water. Tests 1 through 6 were performed with an initial surface elevation $0.3 \mathrm{~cm}$ lower than all subsequent tests. Pre-spray surface densities were calculated using a correction for material removed during preparation of the $45^{\circ}$ sloped tray rim to top surface transitions. Pre-spray surface densities were $1.14 \pm 0.01,1.15 \pm 0.03$, and $1.10 \pm 0.03 \mathrm{~g} / \mathrm{cm}^{3}$ for Idaho, Hanford, and McGee Ranch soils, respectively. All batches of Idaho soil were similar in density within $\pm 0.01 \mathrm{~g} / \mathrm{cm}^{3}$.

\subsection{APPLIED EOLLAN EROSIVE STRESSES}

The primary emphasis of wind tunnel tests of fugitive dust suppressant agents was to provide data for side-by-side comparisons of the various treatment levels and conditions. Thus, it was important to reproduce from test to test the preparation of surfaces, application of agents, aging, and wind and sand conditions during the tests. Specific procedures were followed in preparing the surfaces to minimize uncertainty. Wind velocities were measured and found to typically range within $\pm 1 \%$ of the target speeds. Wind erosion parameters were determined. Sand flow rates and the kinetic energy of sand grains were likewise well controlled.

The erosion parameters friction velocity, $\mathrm{u}^{*}$, and roughness height, $\mathrm{z}_{0}$, were measured previously (Ligotke 1993 and Ligotke and Klopfer 1990) for surfaces similar to the undisturbed surfaces in the present study. The $u^{*}$ was found to be a linear function of mean wind speed and to increase from about 0.8 to $1.6 \mathrm{~m} / \mathrm{s}$ over boundary layer surfaces used in the present study. Over soil (smooth) and pea gravel admixture surfaces, $\mathrm{u}^{*}$ was found to increase from 0.6 to $1.1 \mathrm{~m} / \mathrm{s}$ and 
TABLE 4.1. Fugitive Dust Control Surface Fixative Agent Tests Performed in a Wind Tunnel Between March and August 1993.

\begin{tabular}{|c|c|c|c|c|c|c|c|}
\hline $\begin{array}{l}\text { Test } \\
\text { Ne. }\end{array}$ & Date & $\begin{array}{l}\text { Soil } \\
\text { Type }\end{array}$ & $\begin{array}{c}\text { Pre-Spray } \\
\text { Density } \\
\left(\mathrm{g} / \mathrm{cm}^{3}\right) \\
\end{array}$ & $\begin{array}{c}\text { Dust } \\
\text { Control } \\
\text { Agent }\end{array}$ & $\begin{array}{c}\text { Solution } \\
\text { Concentration }\end{array}$ & $\begin{array}{c}\text { Application } \\
\text { Quantity } \\
\left(\mathrm{L} / \mathrm{m}^{2}\right) \\
\end{array}$ & $\begin{array}{c}\text { Surface } \\
\text { Aging } \\
\text { Conditions }\end{array}$ \\
\hline 1-trial & $3 / 22 / 93$ & Hanford & 1.06 & PS & (a) & (a) & Standard \\
\hline 2-trial & $3 / 25 / 93$ & Hanford & -1.03 & Wet Control & $\mathrm{n} / \mathrm{a}$ & 1.4 & Standard \\
\hline 3 & $3 / 30 / 93$ & Idaho & 1.03 & PS & $1.0: 100$ & 1.0 & Standard \\
\hline 4 & $3 / 30 / 93$ & Idaho & 1.11 & PS & $2.5: 100$ & 4.0 & Standard \\
\hline 5 & $4 / 02 / 93$ & Idaho & 1.08 & Dry Control & $n / a$ & 0.0 & Standard \\
\hline 6 & $4 / 02 / 93$ & Idaho & 1.08 & Wet Control & $\mathrm{n} / \mathrm{a}$ & 2.0 & Standard \\
\hline 7 & $4 / 05 / 93$ & Idaho & 1.14 & PS & $1.0: 100$ & 2.0 & Standard \\
\hline 8 & $4 / 05 / 93$ & Idaho & 1.13 & PS & $2.5: 100$ & 1.0 & Standard \\
\hline 9 & $4 / 06 / 93$ & Idaho & 1.12 & PS & $1.0: 100$ & 1.0 & Standard \\
\hline 10 & $4 / 06 / 93$ & Idaho & 1.14 & PS & $2.5: 100$ & 4.0 & Standard \\
\hline 11 & $4 / 09 / 93$ & Idaho & 1.12 & Dry Control & $\mathrm{n} / \mathrm{a}$ & 0.0 & Standard \\
\hline 12 & $4 / 09 / 93$ & Idaho & 1.16 & Wet Control & $\mathrm{n} / \mathrm{a}$ & 2.0 & Standard \\
\hline 13 & $4 / 12 / 93$ & Idaho & 1.14 & PS & $1.0: 100$ & 2.0 & Standard \\
\hline 14 & $4 / 12 / 93$ & Idaho & 1.17 & PS & $1.0: 100$ & 2.0 & uv-cycle \\
\hline 15 & $4 / 13 / 93$ & Idaho & 1.14 & PS & $2.5: 100$ & 2.0 & Standard \\
\hline 16 & $4 / 13 / 93$ & Idaho & 1.14 & PS & $1.0: 100$ & 2.0 & uv-cycle \\
\hline 17 & $4 / 19 / 93$ & Idaho & 1.14 & PS & $2.5: 100$ & 1.0 & Standard \\
\hline 18 & $4 / 19 / 93$ & Idaho & 1.14 & PS & $2.5: 100$ & 2.0 & Standard \\
\hline 19 & $4 / 21 / 93$ & Idaho & 1.14 & PS & $1.0: 100$ & 2.0 & Moisture-cy \\
\hline 20 & $4 / 21 / 93$ & Idaho & 1.14 & PS & $1.0: 100$ & 2.0 & Moisture-cyc \\
\hline 21 & $4 / 22 / 93$ & Idaho & 1.14 & Dry Control & $\mathrm{n} / \mathrm{a}$ & 0.0 & Standard \\
\hline 22 & $4 / 22 / 93$ & Idaho & 1.15 & Wet Control & $\mathrm{n} / \mathrm{a}$ & 2.0 & Standard \\
\hline 23 & $4 / 27 / 93$ & Idaho & 1.14 & PS & $0.7: 100$ & 1.0 & Standard \\
\hline 24 & $6 / 07 / 93$ & Idaho(2) & 1.14 & $\mathrm{XDCA}$ & $1: 2$ & 4.5 & Standard \\
\hline 25 & 6/07/93 & Idaho(2) & 1.14 & XDCA & $1: 2$ & 1.1 & Standard \\
\hline 26 & $6 / 11 / 93$ & Idaho(2) & 1.14 & Dry Control & $\mathrm{n} / \mathrm{a}$ & 0.0 & Standard \\
\hline 27 & $6 / 11 / 93$ & Idaho(2) & 1.15 & Wet Control & $\mathrm{n} / \mathrm{a}$ & 2.0 & Standard \\
\hline 28 & $6 / 11 / 93$ & Idaho(2) & 1.14 & PS & $1.0: 100$ & 2.0 & Standard \\
\hline 29 & $6 / 11 / 93$ & Idaho(2) & 1.14 & PS & $1.0: 100$ & 2.0 & Standard \\
\hline 30 & $6 / 18 / 93$ & Idaho(2) & 1.14 & XDCA & $1: 2$ & 4.5 & Standard \\
\hline 31 & $6 / 18 / 93$ & Idaho(2) & 1.13 & $\mathrm{XDCA}$ & $1: 1$ & 4.5 & Standard \\
\hline 32 & $6 / 22 / 93$ & Idaho(2) & 1.15 & XDCA & $1: 2$ & 1.1 & Standard \\
\hline 33 & $6 / 22 / 93$ & Idaho(2) & 1.15 & XDCA & $1: 1$ & 4.5 & Standard \\
\hline 34 & $6 / 22 / 93$ & Idaho(2) & 1.14 & $\mathrm{XDCA}$ & $1: 2$ & 4.5 & uv-cycle \\
\hline 35 & $6 / 22 / 93$ & Idaho(2) & 1.14 & XDCA & $1: 2$ & 4.5 & uv-cycle \\
\hline 36 & $6 / 28 / 93$ & Idaho(2) & 1.16 & Dry Control & $\mathrm{n} / \mathrm{a}$ & 0.0 & Standard \\
\hline 37 & $6 / 28 / 93$ & Idaho(2) & 1.16 & Wet Control & $\mathrm{n} / \mathrm{a}$ & 2.0 & Standard \\
\hline 38 & $6 / 28 / 93$ & Idaho(2) & 1.16 & PS & $1.0: 100$ & 4.0 & Standard \\
\hline 39 & $6 / 28 / 93$ & Idaho(2) & 1.16 & PS & $1.0: 100$ & 4.0 & Standard \\
\hline 40 & $7 / 03 / 93$ & Idaho(2) & 1.15 & $\mathrm{XDCA}$ & $1: 2$ & 2.3 & Standard \\
\hline 41 & $7 / 03 / 93$ & Idaho(2) & 1.14 & XDCA & $1: 2$ & 2.3 & Standard \\
\hline 42 & $7 / 07 / 93$ & Idaho(2) & 1.15 & FPW & $1: 4$ & 2.0 & Standard \\
\hline 43 & $7 / 07 / 93$ & Idaho(2) & 1.15 & FPW & $1: 4$ & 4.0 & Standard \\
\hline 44 & $7 / 08 / 93$ & Idaho(2) & 1.14 & XDCA & $1: 2$ & 4.5 & Moisture-cy \\
\hline 45 & $7 / 08 / 93$ & Idaho(2) & 1.15 & XDCA & $1: 2$ & 4.5 & Moisture-cyc \\
\hline 46 & $7 / 12 / 93$ & Hanford & 1.20 & Wet Control & $\mathrm{n} / \mathrm{a}$ & 2.0 & Standard \\
\hline 47 & $7 / 12 / 93$ & Hanford & 1.14 & Wet Control & $\mathrm{n} / \mathrm{a}$ & 2.0 & Standard \\
\hline 48 & $7 / 12 / 93$ & Idaho(2) & 1.14 & FPW & 1:4 & 4.0 & Standard \\
\hline 49 & $7 / 12 / 93$ & Idaho(2) & 1.15 & FPW & $1: 1$ & 4.0 & Standard \\
\hline 50 & $7 / 13 / 93$ & Hanford & 1.11 & PS & $1.0: 100$ & 2.0 & Standard \\
\hline
\end{tabular}


TABLE 4.1. (contd.)

\begin{tabular}{|c|c|c|c|c|c|c|c|}
\hline $\begin{array}{l}\text { Test } \\
\text { No. } \\
\end{array}$ & Date & $\begin{array}{l}\text { Soil } \\
\text { Type }\end{array}$ & $\begin{array}{c}\text { Pre-Spray } \\
\text { Density } \\
\left(\mathrm{g} / \mathrm{cm}^{3}\right) \\
\end{array}$ & $\begin{array}{c}\text { Dust } \\
\text { Control } \\
\text { Agent }\end{array}$ & $\begin{array}{c}\text { Solution } \\
\text { Concentration }\end{array}$ & $\begin{array}{c}\text { Application } \\
\text { Quantity } \\
\left(\mathrm{L} / \mathrm{m}^{2}\right) \\
\end{array}$ & $\begin{array}{c}\text { Surface } \\
\text { Aging } \\
\text { Conditions }\end{array}$ \\
\hline 51 & $7 / 13 / 93$ & Hanford & 1.11 & PS & $1.0: 100$ & 2.0 & Standard \\
\hline 52 & $7 / 16 / 93$ & McGee Ranch & 1.09 & Wet Control & $n / a$ & 2.0 & Standard \\
\hline 53 & $7 / 16 / 93$ & McGee Ranch & 1.13 & Wet Control & $\mathbf{n} / \mathbf{a}$ & 2.0 & Standard \\
\hline 54 & $7 / 16 / 93$ & Idaho(2) & 1.15 & FPW & $1: 2$ & 4.0 & Standard \\
\hline 55 & $7 / 16 / 93$ & Idaho(3) & 1.13 & FPW & $1: 9$ & 4.0 & Standard \\
\hline 56 & $7 / 20 / 93$ & Hanford & 1.15 & FPW & $1: 4$ & 4.0 & Standard \\
\hline 57 & $7 / 20 / 93$ & Hanford & 1.15 & FPW & $1: 4$ & 4.0 & Standard \\
\hline 58 & $7 / 20 / 93$ & Idaho(3) & 1.14 & FPW & $1: 4$ & 4.0 & uv-cycle \\
\hline 59 & $7 / 20 / 93$ & Idaho(3) & 1.14 & FPW & $1: 4$ & 4.0 & uv-cycle \\
\hline 60 & $7 / 22 / 93$ & Hanford & 1.16 & Dry Control & $n / a$ & 0.0 & Standard \\
\hline 61 & $7 / 22 / 93$ & Hanford & 1.17 & Dry Control & $\mathrm{n} / \mathrm{a}$ & 0.0 & Standard \\
\hline 62 & $7 / 22 / 93$ & Idaho(3) & 1.16 & FPW & $1: 4$ & 4.0 & Moisture-cycle \\
\hline 63 & $7 / 22 / 93$ & Idaho(3) & 1.13 & FPW & $1: 4$ & 4.0 & Moisture-cycle \\
\hline 64 & $7 / 24 / 93$ & Hanford & 1.17 & XDCA & $1: 2$ & 4.5 & Standard \\
\hline 65 & $7 / 24 / 93$ & Hanford & 1.16 & XDCA & $1: 2$ & 4.5 & Standard \\
\hline $65 a$ & $7 / 26 / 93$ & Hanford & 1.16 & XDCA & $1: 2$ & 4.5 & Standard \\
\hline $65 \mathrm{~b}$ & $8 / 03 / 93$ & Hanford & 1.16 & XDCA & $1: 2$ & 4.5 & Standard \\
\hline 66 & $7 / 24 / 93$ & McGee Ranch & 1.07 & Dry Control & $\mathrm{n} / \mathrm{a}$ & 0.0 & Standard \\
\hline 67 & $7 / 24 / 93$ & McGee Ranch & 1.11 & Dry Control & $\mathrm{n} / \mathrm{a}$ & 0.0 & Standard \\
\hline 68 & $7 / 26 / 93$ & Idaho(3) & 1.16 & FPW & $1: 9$ & 4.0 & Standard \\
\hline 69 & $7 / 26 / 93$ & Idaho(3) & 1.15 & FPW & $1: 4$ & 2.0 & Standard \\
\hline
\end{tabular}

(a) The surface prepared for Test 1 was sprayed with two PS treatment levels, $1.0: 100$ and $1.0 \mathrm{~L} / \mathrm{m}^{2}$ on the north half, and $2.5: 100$ and $4.0 \mathrm{~L} / \mathrm{m}^{2}$ on the south.

0.8 to about $1.7 \mathrm{~m} / \mathrm{s}$, respectively for wind speeds of 10 and $20 \mathrm{~m} / \mathrm{s}$. Because the undisturbed surfaces in the present study were similar to the soil (smooth) surfaces tested previously, $u^{*}$ was known to be about 1.1 and $1.4 \mathrm{~m} / \mathrm{s}$ at wind tunnel wind speeds of 20 and $25 \mathrm{~m} / \mathrm{s}$, respectively. For such surfaces, $\mathrm{z}_{0}$ was found previously to be about 0.003 to $0.004 \mathrm{~cm}$.

The disturbed surfaces in the present study formed rough ridges and furrows that caused greater erosive stresses than over the smooth, undisturbed surfaces. Measurements of the air-flow boundary layer were made over the disturbed surface from Test 65 at 10 and $20 \mathrm{~m} / \mathrm{s}$ to provide an indication of the erosive stresses over all disturbed surfaces. The surface appeared to represent an average of the disturbed surfaces. The $u^{*}$ increased from 0.85 to $1.67 \mathrm{~m} / \mathrm{s}$, at 10 and $20 \mathrm{~m} / \mathrm{s}$, respectively, and $z_{0}$ was $0.052 \mathrm{~cm}$. Because $u^{*}$ varies linearly with wind speed, $u^{*}$ at $25 \mathrm{~m} / \mathrm{s}$ was estimated to be $2.1 \mathrm{~m} / \mathrm{s}$.

Based on the $u^{*}$ and $z_{0}$ parameters, the surface shear stress, $\tau_{s}$, caused by wind on the undisturbed test surfaces in the present study was estimated [Equation (3.2)] to be approximately 1.5 and $2.4 \mathrm{~N} / \mathrm{m}^{2}$ at wind speeds of 20 and $25 \mathrm{~m} / \mathrm{s}$, respectively. In a similar fashion, $\tau_{\mathrm{s}}$ on the 
disturbed surfaces was 3.4 and $-5.3 \mathrm{~N} / \mathrm{m}^{2}$ at 20 and $25 \mathrm{~m} / \mathrm{s}$, respectively. The mass flow rates, or intensities, of saltating sand in the present study were 170 and $250 \mathrm{~g} /\left(\mathrm{m}^{2-\mathrm{s}}\right)$ for the 20 and 25 $\mathrm{m} / \mathrm{s}$ wind speeds, respectively.

\subsection{SUREACE DEELATION RATE RESULTS}

Wind tunnel test data were analyzed to provide information on the influence of fugitive dust suppressants on two soil types exposed to eolian stresses. The agents were applied using a range of solution concentrations and application quantities, and were aged by exposure to standard, uvcycle, and moisture-cycle conditions before testing. A list of all tests including measured subtest duration, wind speed, and mass change, as well as calculated deflation rate, are shown in Appendix A-A. Appendix A-B shows this information grouped by test parameter. The control tests of McGee Ranch soil were supported by another study but were included in the data sets because of their applicability. The performance under conditions of eolian stress of the control surfaces are described as are the performance of PS, XDCA, and FPW. The majority of the tests were performed using Idaho loamy soil; however, the few tests performed using a Hanford sandy soil provided an indication of the importance of soil type on the performance of dust control agents and are described. Summary information is presented in this section. Additional results are listed in Appendix A-A and summarized in groups in Appendix A-B. Figures presented in this section show all data prior to surface failure; for cases that failed after a given subtest, subsequent subtests were excluded from the figures. In other cases, surface failure is noted on the figures.

Comparisons of the various dust control agents by test parameters and subtest are listed in tables in the following sections. The following description refers to those tables. The comparisons shown in the tables were made by considering the ratio of the agent-protected surface to the corresponding wet control deflation rates. A significant difference was judged to have occurred if the ratio of deflation rates from the agent-protected to the wet control surfaces was always less than unity for the range of uncertainties associated with the data. A significant difference, for ranges of ratios less than unity, indicates that the dust control agent provided protection superior to the water crust of the wet control. The smaller the maximum ratio of deflation rates, the better the protection provided by the dust control agent. For example, if the deflation rate from an agent-protected surface is $0.11 \pm 0.067 \mathrm{~g} /\left(\mathrm{m}^{2}-\mathrm{s}\right)$ and that from the corresponding wet control is $1.2 \pm 0.54 \mathrm{~g} / \mathrm{m}\left(\mathrm{m}^{2}-\mathrm{s}\right)$, then the range of possible deflation rate ratios is 2.5 to $27 \%$, and the difference is significant because the range does not span unity (100\%). This conservative approach was selected based on the small number of replicate tests and the wide variation in the Idaho soil wet control results. Smaller variation in the wet controls was expected and would have provided more easily interpreted results. All surfaces were protected from 
deflation during Subtests 1 and 2 and the surfaces were disturbed as described in Section 3.4 between Subtests 4 and 5 .

\subsubsection{Dry and Wet Control Surfaces (Not Treated)}

Dry and wet control surfaces were prepared from both Idaho and Hanford soils and tested to provide a baseline of deflation rates from untreated surfaces. As described above, similar tests of Mcisee Ranch silt-loam are also reported. The dry controls differed from treated surfaces by having no additional water spray added. The wet controls received $2.0 \mathrm{~L} / \mathrm{m}^{2}$ of water spray. It should be noted that the wet controls were allowed to dry prior to testing. This is in contrinst to normal field applications of water where the surface is kept wet by repeated applications. As expected, the dry controls produced the greatest deflation rates. The cohesiveness of the soils and their resistance to wind erosion varied greatly and was apparently related to sand content. Figure 4.1 shows the influence of wind speed on deflation rate from the dry controls for each soil type. With the greatest sand content, Hanford soil deflated at rates decreasing from about 50- to about 3 fold greater as wind speed increased from 10 to $20 \mathrm{~m} / \mathrm{s}$. No uncertainty limits were available for the Hanford soil case because the tests were performed at different wind speeds to cover the range of 10 to $20 \mathrm{~m} / \mathrm{s}$ without depleting the test surfaces. At a wind tunnel wind speed of $20 \mathrm{~m} / \mathrm{s}$, deflation rates averaged $0.14 \pm 0.10,6.4$, and $0.45 \pm 0.28 \mathrm{~g} /\left(\mathrm{m}^{2}-\mathrm{s}\right)$ for both Idaho soils, Hanford soil, and McGee Ranch soil, respectively. The rate of increase in deflation rate with wind speed was proportional to expbu, where $b=0.18 \pm 0.02$, and $u=$ mean wind speed. These measured deflation rates represent soil mass loss from freshly exposed dry soil surfaces. A comparison of the undisturbed test cases for all soil types is shown in Figure 4.2.

The water-sprayed wet controls formed crusts of soluble materials on the soil surfaces that provided protection from eolian stresses. In the case of the Idaho loamy soil (Batches 1 and 2 were tested), the water crust provided good protection of the undisturbed surfaces but was subject to failure at high wind speed after the surfaces were disturbed. In contrast, undisturbed Hanford sandy soil failed on exposure to saltating sand stress at $20 \mathrm{~m} / \mathrm{s}$. McGee Ranch soil provided an intermediate case as it also failed before being disturbed, but did not fail until saltating sand stress was applied at $25 \mathrm{~m} / \mathrm{s}$. The degree of protection provided by the crust formed after water was sprayed on the surfaces was apparently related to the sand content of the soils. The more sand present, the less well the water crust protected the surfaces. The soluble materials content of the soils was not known, but also likely affected the durability of the crusts. Figure 4.3 shows a comparison of all soil types in the undisturbed condition. Figure 4.4 shows both dry and wet control Idaho soils in the undisturbed condition. Figure 4.5 shows wet control Idaho soils in both the undisturbed and disturbed conditions. The figures compare Idaho soil Batches 1 and 2. 


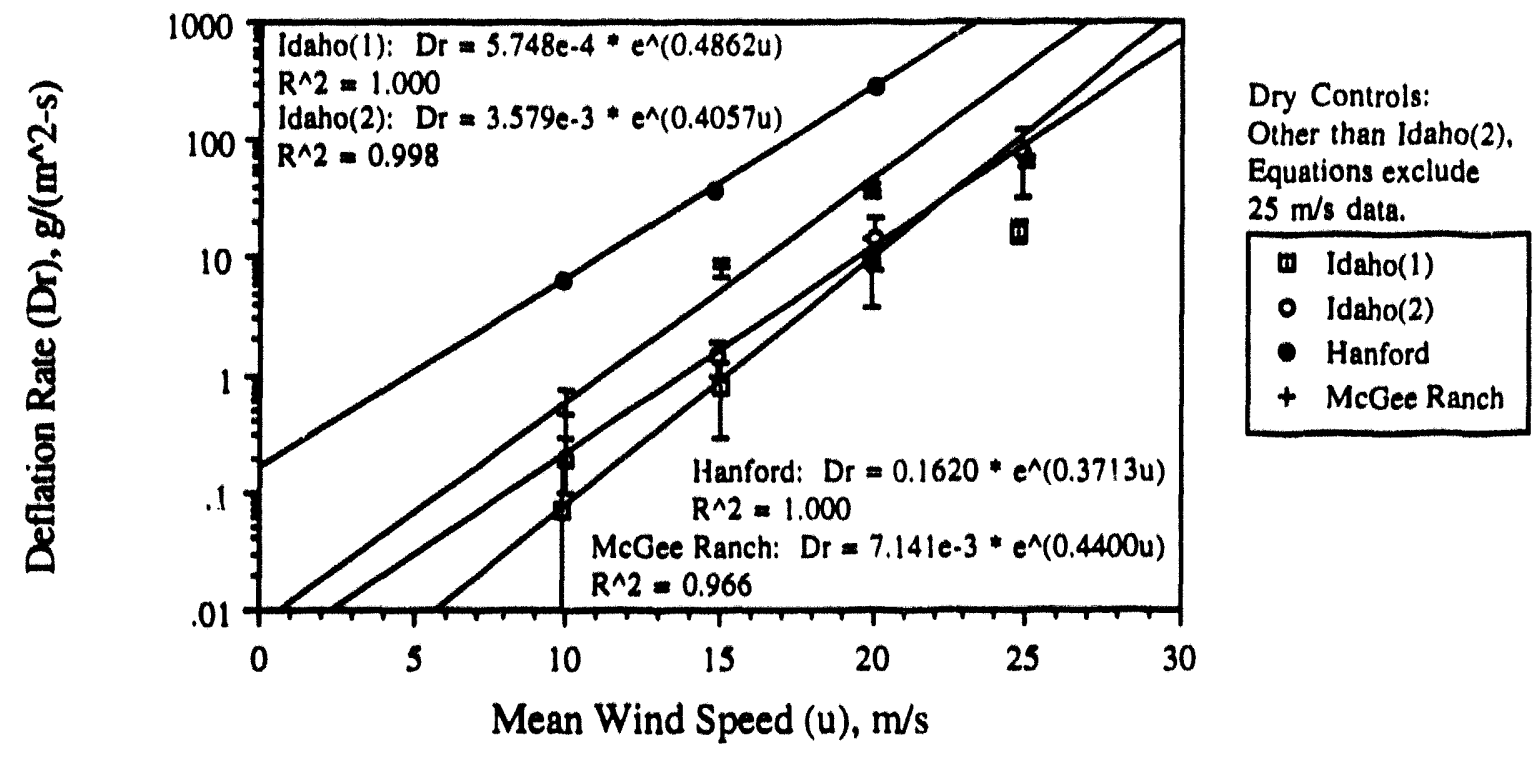

EIGURE 4.1 Deflation Rate from Dry Control Soil Surfaces Versus Mean Wind Speed

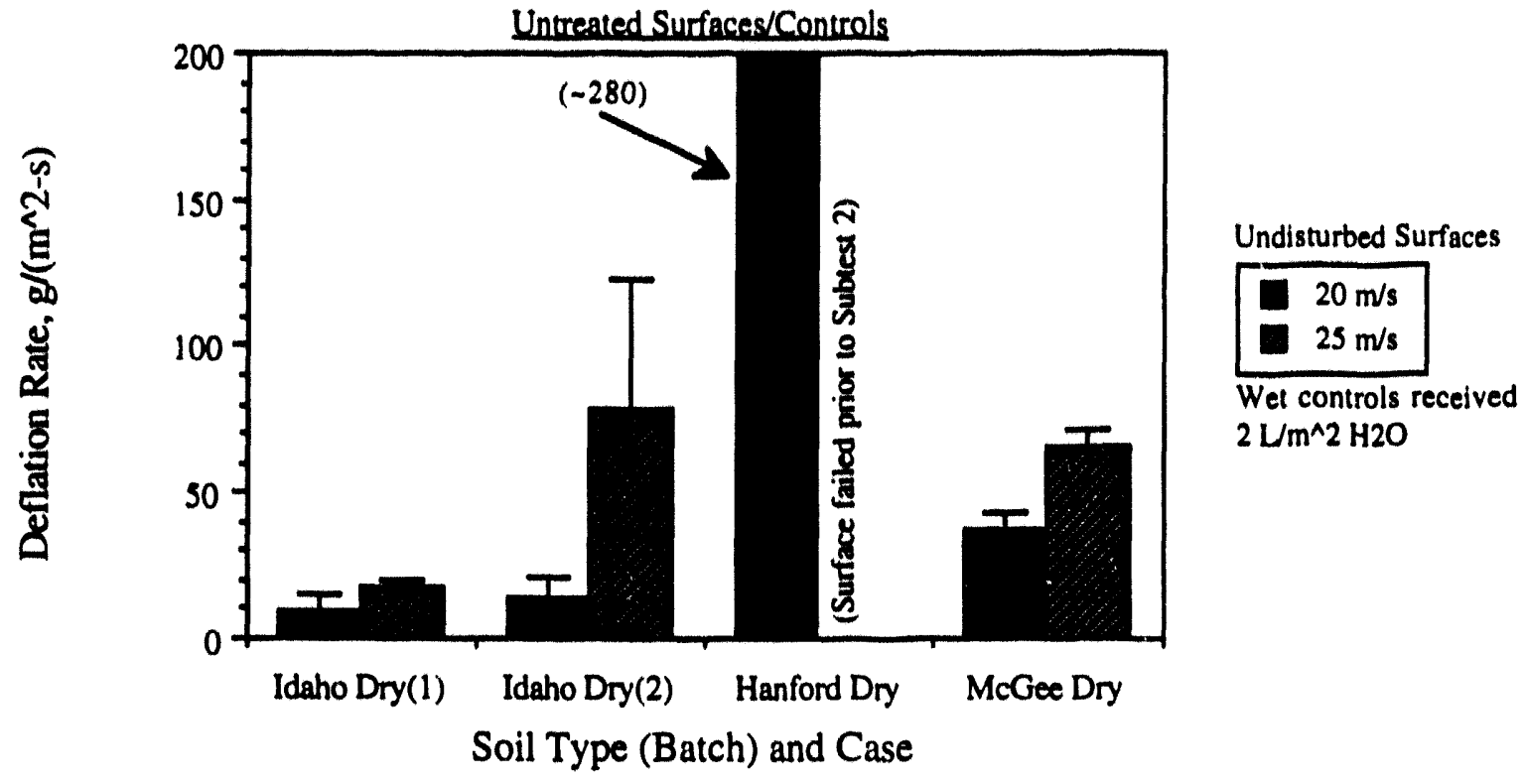

EIGURE 4.2 Deflation Rate From Undisturbed Dry Control Soil Surfaces 


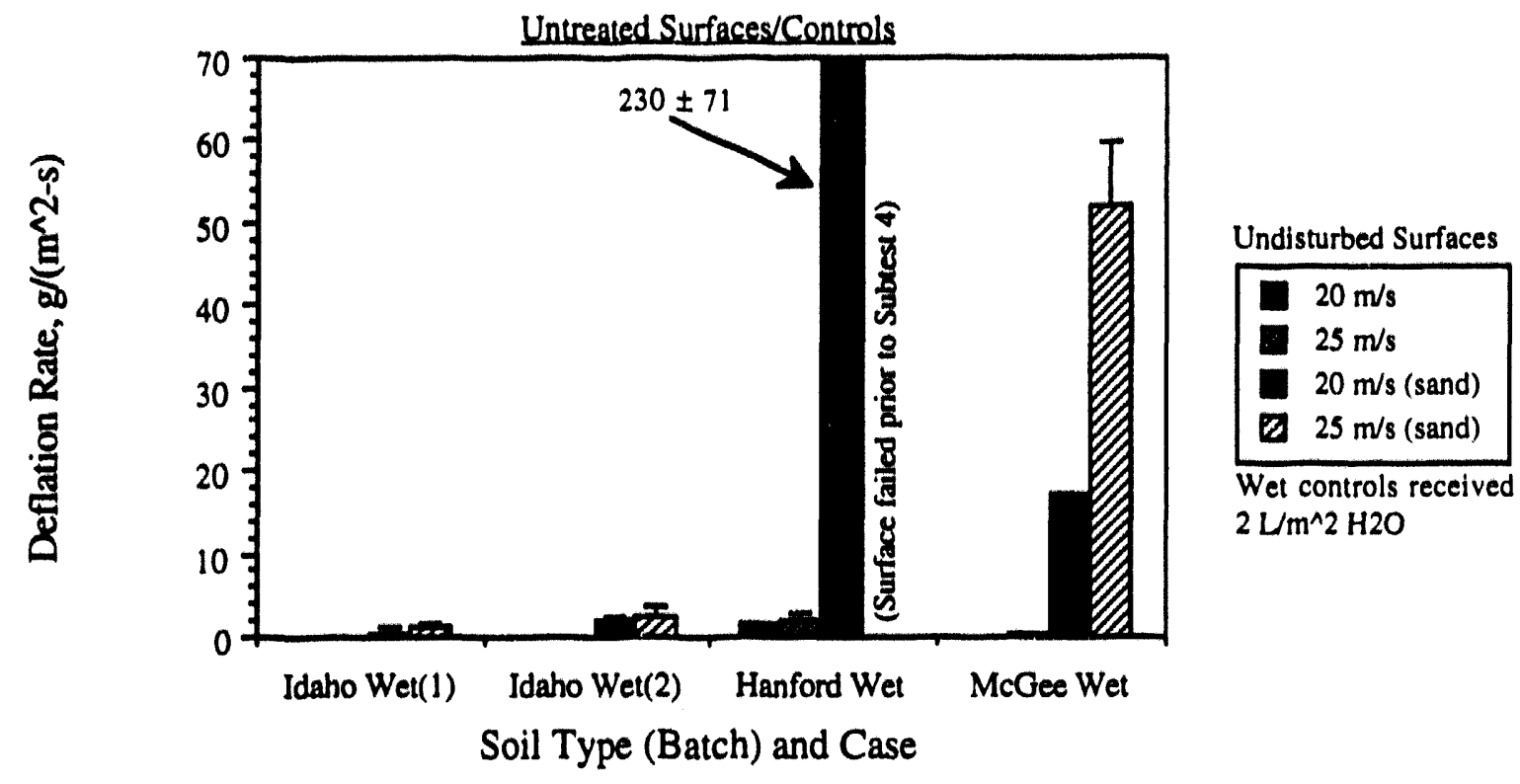

EIGURE 4.3 Deflation Rate from Undisturbed Wet Control Soil Surfaces

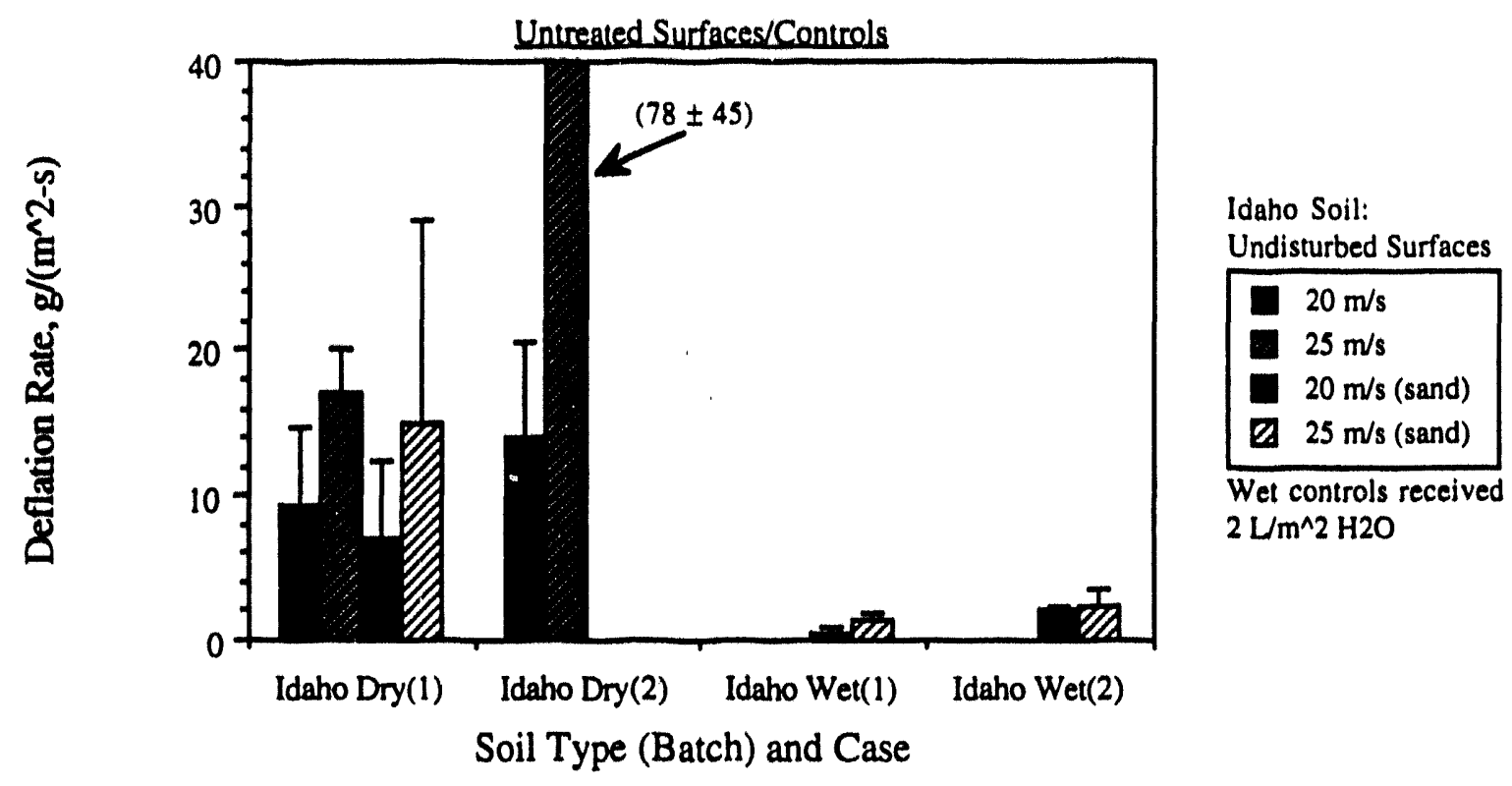

EIGURE 4.4 Deflation Rate from Undisturbed Idaho Soil Wet Control Surfaces 


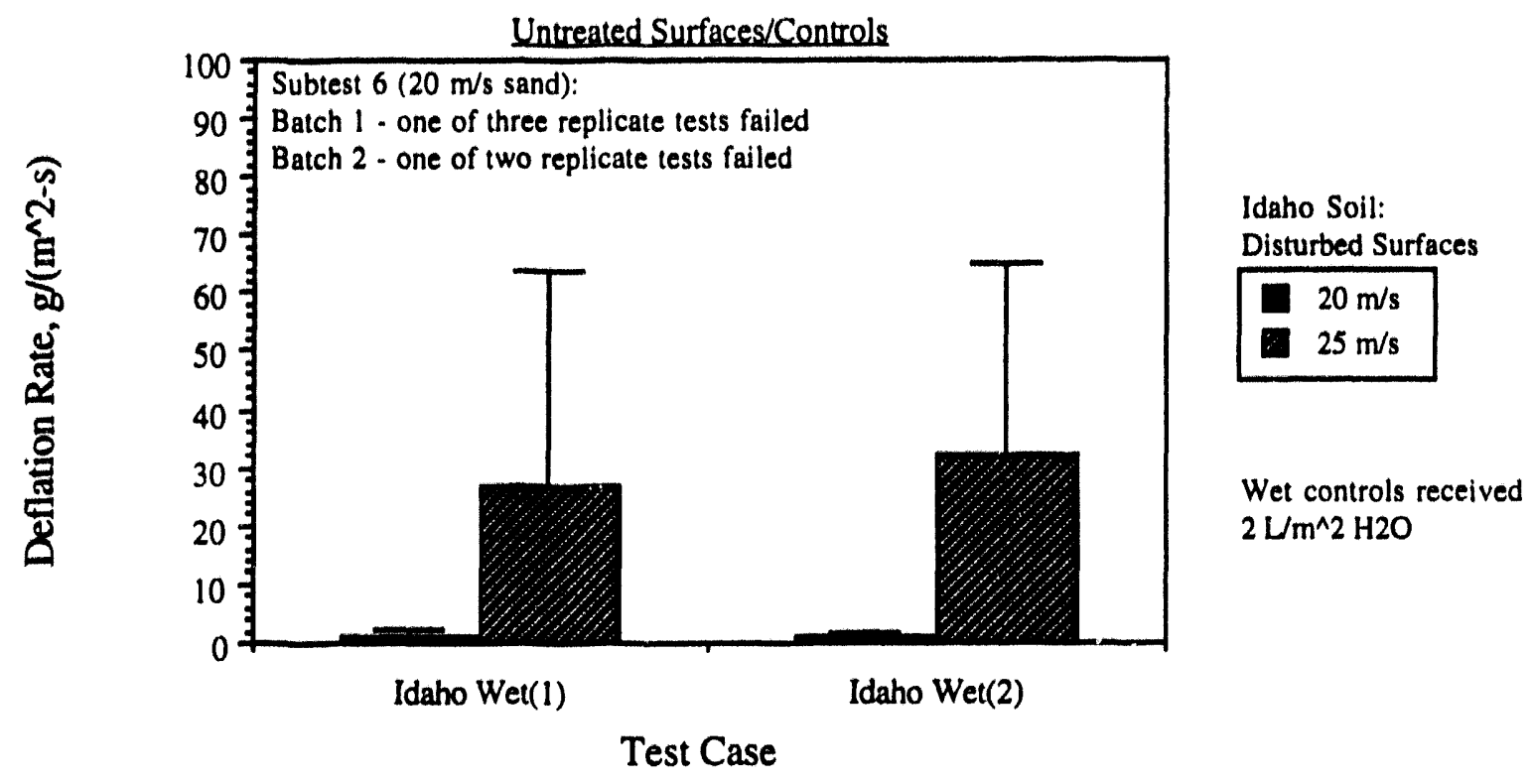

EIGURE 4.5 Deflation Rate from Disturbed Idaho Soil Wet Control Surfaces

Results of the Idaho soil wet controls from Batch 1 were used as a baseline for comparison with the fugitive dust control agent results in the figures in the following sections; measured deflation rates were $0.54 \pm 0.50,1.3 \pm 0.48,1.1 \pm 1.1$, and $27 \pm 37 \mathrm{~g} /\left(\mathrm{m}^{2}-\mathrm{s}\right)$ during Subtests $3,4,5$, and 6, respectively. Results of the Idaho soil wet controls from Batches 1 and 2 were used as a baseline for comparison with the fugitive dust control agent results; measured deflation rates were $1.2 \pm 0.95,1.2 \pm 0.54,1.1 \pm 0.86$, and $29 \pm 31 \mathrm{~g} /\left(\mathrm{m}^{2}-\mathrm{s}\right)$ during Subtests $3,4,5$, and 6 , respectively. Similar results for Hanford soil wet controls were $230 \pm 71 \mathrm{~g} /\left(\mathrm{m}^{2}-\mathrm{s}\right)$ for Subtest 3; the Hanford soil wet controls failed at the end of Subtest 3.

The most significant difficulty in comparing wet controls with agent-protected surfaces is the large uncertainty in the Idaho soil wet control test results. Based on past results of tests with McGee Ranch silt-loam soils, we had anticipated better test-to-test repeatability. The presence of a greater fraction of loam in the Idaho soil might have caused the poorer repeatability in the present study. However, comparison with agent-protected surfaces were made and did indicate the more obvious agent treatments. It should be noted that the Hanford sandy soil would be expected to result in better test-to-test repeatability because of its high sand content, low loam content, and uniformity. 


\subsubsection{Potato Starch Surface Crusts}

Results discussed in this section refer to Idaho soil surfaces. Hanford soil surfaces protected by potato starch solutions are discussed in Section 4.3.5. The PS surface crusts were prepared using two solution concentrations (1.0 and $2.5 \%)$ and three application quantities (1, 2, and $4 \mathrm{~L} / \mathrm{m}^{2}$ ). Tests were performed of all combinations of the two parameters. Based on early results, the "standard" case was selected to be $1.0 \%$ at $2 \mathrm{~L} / \mathrm{m}^{2}$. This case was used to test the impact of surface aging conditions (uv-cycle and moisture-cycle).

In general, application of PS to Idaho soil improved resistance to wind erosion, although the degree of improvement at the least application $\left(1.0 \%\right.$ and $\left.1 \mathrm{~L} / \mathrm{m}^{2}\right)$ was not significant based on the limited number of replicate tests performed. Rather than being a function of starch mass applied per area of surface, the results indicated that the $2.5 \%$ solution provided the best surface protection even when applied at $1 \mathrm{~L} / \mathrm{m}^{2}$. It is possible this result occurred because the $1.0 \%$ solution washed the starch further into the surface and reduced its effectiveness. Figures 4.6 and 4.7 show the results of all tests compared to the wet control surfaces. Negative deflation rate results indicate that the rough surfaces actually gained mass from depositing sand particles during Subtests $3,4,7$, and 8 (saltating sand subtests). This was most pronounced for the disturbed surfaces, which were broken into rough ridges and furrows. Sand was trapped in the furrows. From the figures, it is clear that all PS applications, with the possible exception of $1.0 \%$ at $1 \mathrm{~L} / \mathrm{m}^{2}$, improved resistance to wind erosion. It is clear (Figure 4.7) that the high concentration, low water PS solution (2.5\% PS at $1 \mathrm{~L} / \mathrm{m}^{2}$ ) provided the best protection. Results of Subtest 6 (disturbed surface, $25 \mathrm{~m} / \mathrm{s}$, no sand) indicated that even increasing the starch content on the surface 4-fold, the $2.5 \%$ at $4 \mathrm{~L} / \mathrm{m}^{2}$ case, did not perform as well. This supports the conclusion that water tends to dilute the effect of the PS.

Figures 4.8 and 4.9 show the impact of surface aging condition on PS crusts. Although uv-cycling did not seem to impact PS crusts, tests of the disturbed surfaces indicated that moisturecycling eliminated the benefit of applying PS to Idaho soil surfaces.

Table 4.2 shows a comparison of PS-treated to wet control Idaho soil surfaces by PS solution concentration and quantity applied. A general description of the table is provided in Section 4.3. The PS formed a superior surface crust in all cases; however, because of uncertainties in the wet controls, significant differences were not measured in all cases. As described above, it can be seen in the table that the $2.5 \%$ PS solution at application quantities of 1 and $2 \mathrm{~L} / \mathrm{m}^{2}$ provided the best overall surface protection with average deflation rates between 0 and $14 \%$ of those from the wet control surfaces. 


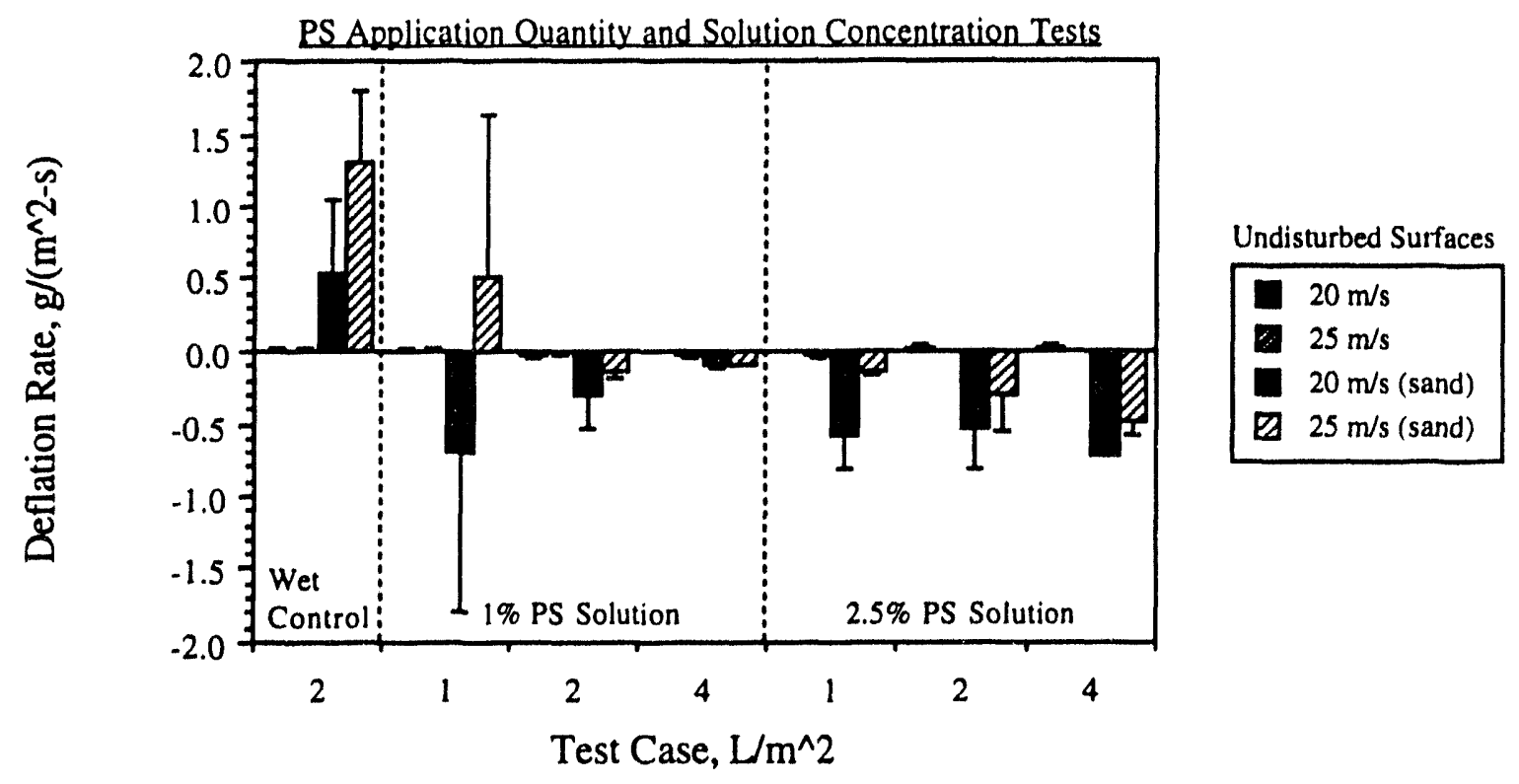

EIGURE 4.6 Deflation Rate from Undisturbed Idaho Soil Protected by Potato Starch

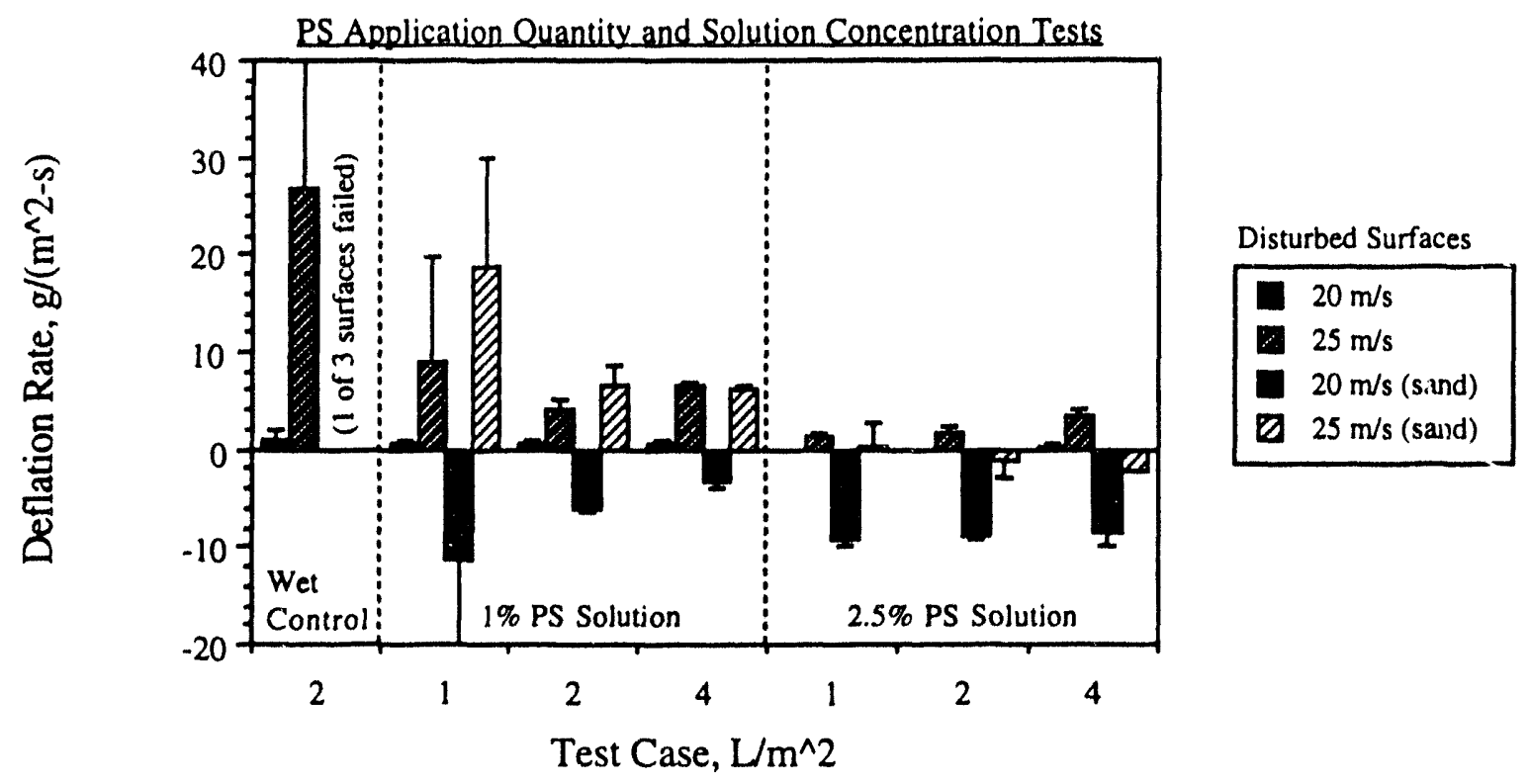

EIGURE 4.7 Deflation Rate from Disturbed Idaho Soil Protected by Potato Starch 


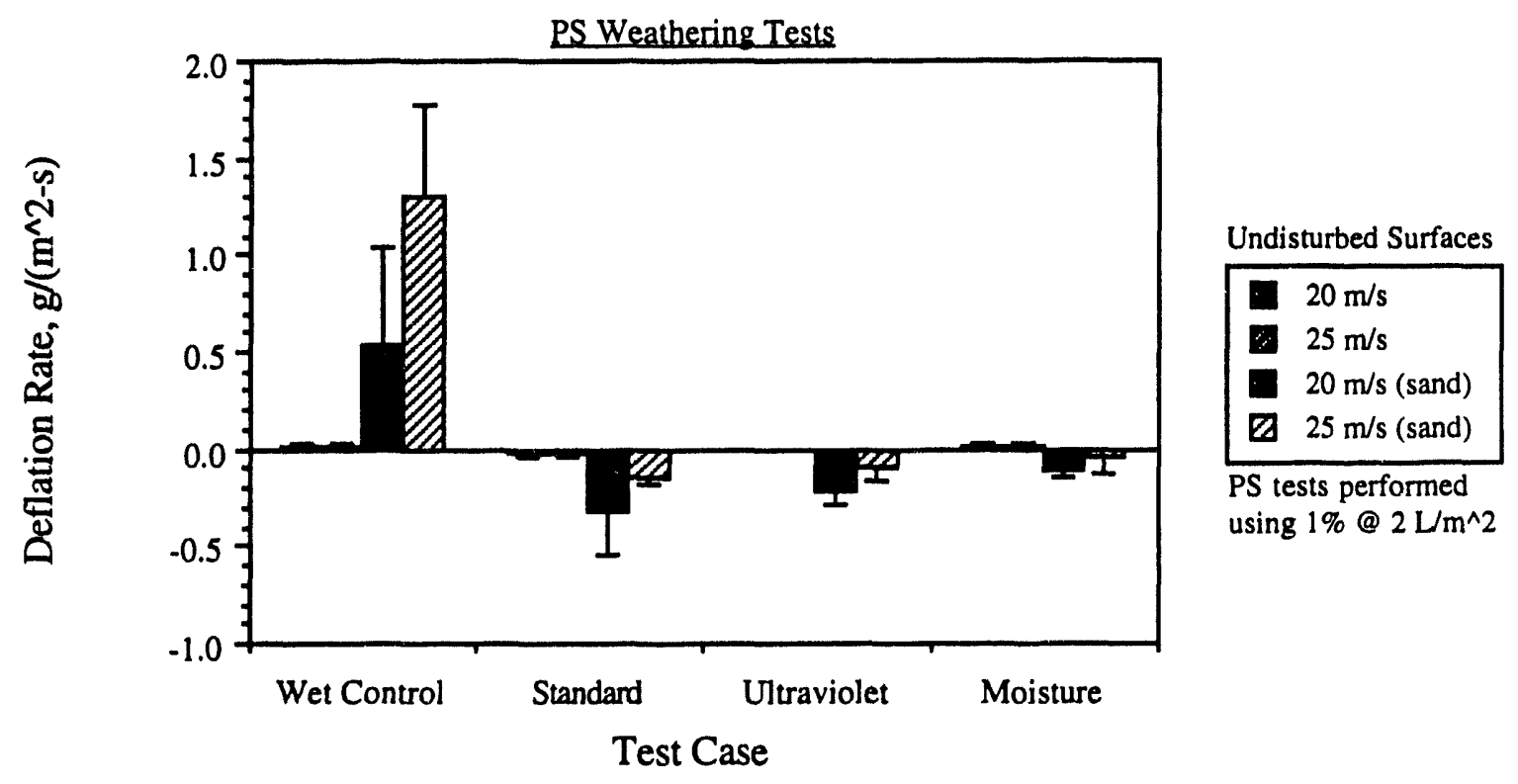

FIGURE 4.8 Influence of Aging Conditions on Undisturbed Potato Starch Crusts

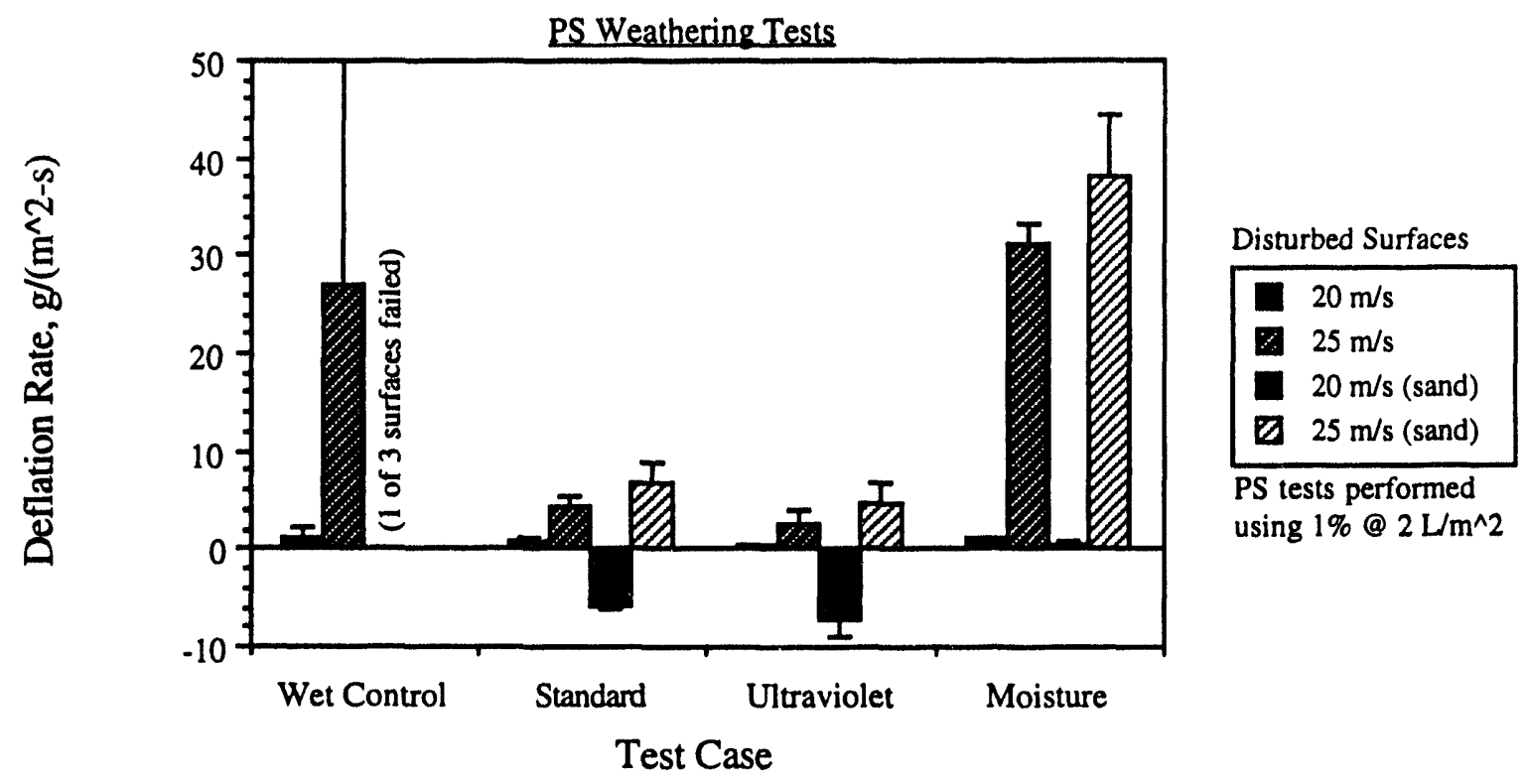

FIGURE 4.9 Influence of Aging Conditions on Disturbed Potato Starch Crusts 
TABLE 4.2. Ratio of Deflation Rates--Potato Starch Agent-Protected to Wet Control Surfaces, Idaho soil only. Data are listed as average, less than a maximum value, or average (range).

Subtest Significant
Difference

$2 \mathrm{~L} / \mathrm{m}^{2} \quad \begin{aligned} & \text { Significant } \\ & \text { Difference }\end{aligned}$

$1 \mathrm{~L} / \mathrm{m}^{2}$

Significant $1.0 \%$ PS Solution/Undisturbed

$320 \mathrm{~m} / \mathrm{s}+$ sand $\quad-0$

$425 \mathrm{~m} / \mathrm{s}+$ sand $\quad 0.43(0-2)$

$1.0 \%$ PS Solution/Disturbed

$520 \mathrm{~m} / \mathrm{s}$

$625 \mathrm{~m} / \mathrm{s}$

$720 \mathrm{~m} / \mathrm{s}+$ sand

$825 \mathrm{~m} / \mathrm{s}+$ sand $\quad<0.30$

$0.57(0.03-5)$

$2.5 \%$ PS Solution/Undisturbed

\begin{tabular}{ll|l}
3 & $20 \mathrm{~m} / \mathrm{s}+$ sand & -0 \\
4 & $25 \mathrm{~m} / \mathrm{s}+$ sand & -0
\end{tabular}

$2.5 \%$ PS Solution/Disturbed

\begin{tabular}{ll|ll|ll|ll}
5 & $20 \mathrm{~m} / \mathrm{s}$ & $0.10(0.4-0.6)$ & yes & $0.14(0.07-0.7)$ & yes & $0.44(0.2-2.5)$ & no \\
6 & $25 \mathrm{~m} / \mathrm{s}$ & $0.045(0.02->1)$ & no & $0.055(0.01->1)$ & no & $0.12(0.05->1)$ & no \\
7 & $20 \mathrm{~m} / \mathrm{s}$ + sand & -0 & yes & -0 & yes & -0 & yes \\
8 & $25 \mathrm{~m} / \mathrm{s}$ + sand & $<0.027$ & yes & -0 & yes & -0 & yes
\end{tabular}

\subsubsection{XDCA Sugar Beet Extract Surface Crusts}

Results discussed in this section refer to Idaho soil surfaces. Hanford soil surfaces protected by XDCA solutions are discussed in Section 4.3.5. The XDCA surface crusts were prepared using two solution concentrations (1:2 and 1:1) and three application quantities $(1.1,4.5$, and $9.2 \mathrm{~L} / \mathrm{m}^{2}$ ). Solutions were prepared volumetrically as described in Section 3.3 and 4.1 . Solution concentrations $1: 2$ and 1:1 represent 33 and 50\% XDCA in water, respectively. Tests were performed of the $1: 1$ at $4.5 \mathrm{~L} / \mathrm{m}^{2}$ and all $1: 2$ cases. Based on early results, the "standard" case was selected to be $1: 2$ at $4.5 \mathrm{~L} / \mathrm{m}^{2}$, and was used to test the impact of surface aging conditions (uv- and moisture-cycling).

The XDCA application quantity tests, performed at a solution concentration of $1: 2$ are shown in Figures 4.10 and 4.11. The crusts performed similar to the wet control with the exception of the 1:2 at $1.1 \mathrm{~L} / \mathrm{m}^{2}$ case, which provided less protection than the wet control case. The XDCA solution concentration tests, performed at an application rate of $4.5 \mathrm{~L} / \mathrm{m}^{2}$ are shown in Figures 4.12 and 4.13. Neither test case resulted in a surface crust providing a significant difference from the wet control. Figures 4.14 and 4.15 show the impact of aging conditions on XDCA surface crusts. Both uv-cycling and moisture-cycling may have reduced the effectiveness 


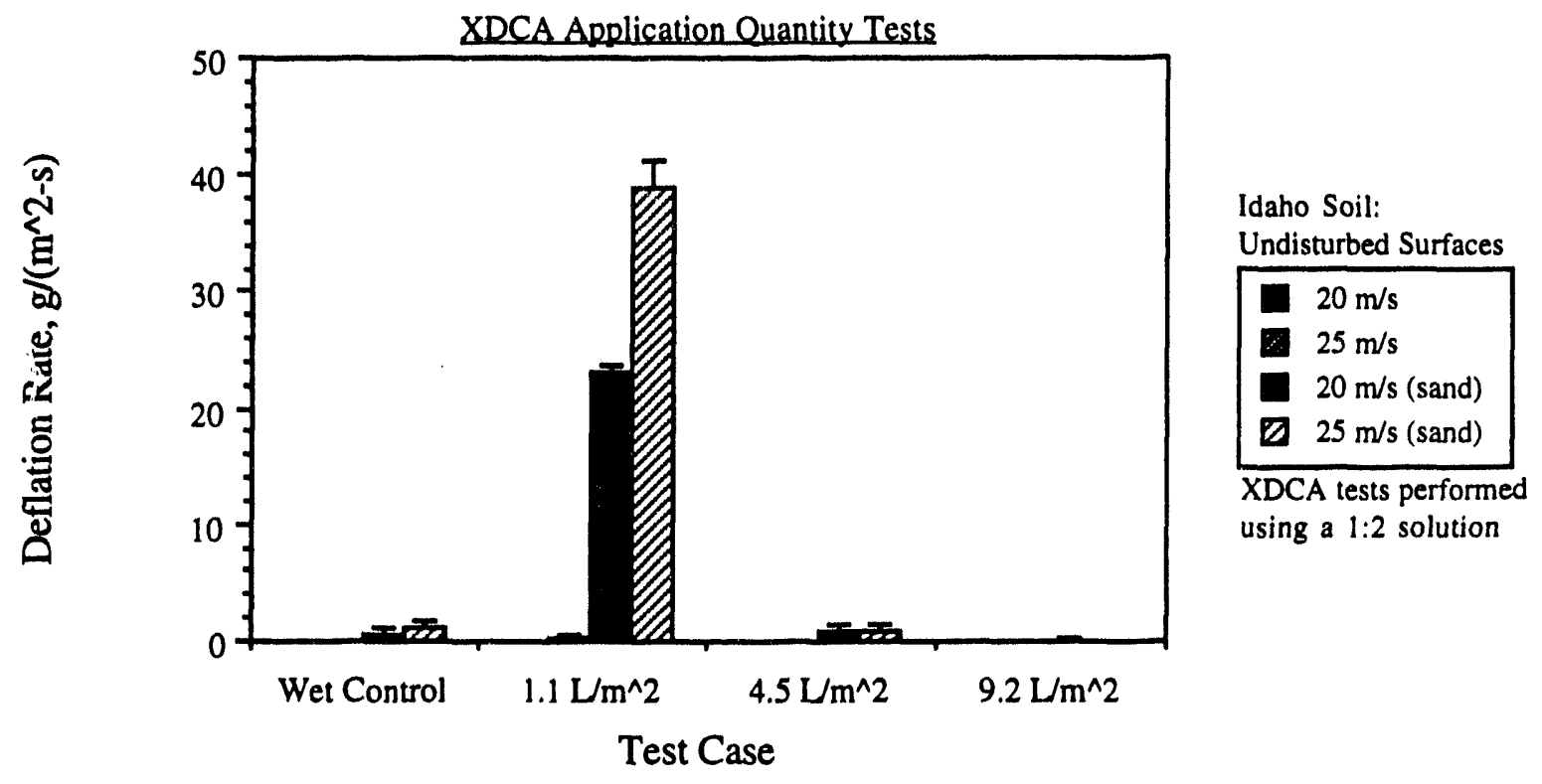

FIGURE 4.10 Undisturbed Idaho Soil Protected by XDCA - Application Quantity Tests

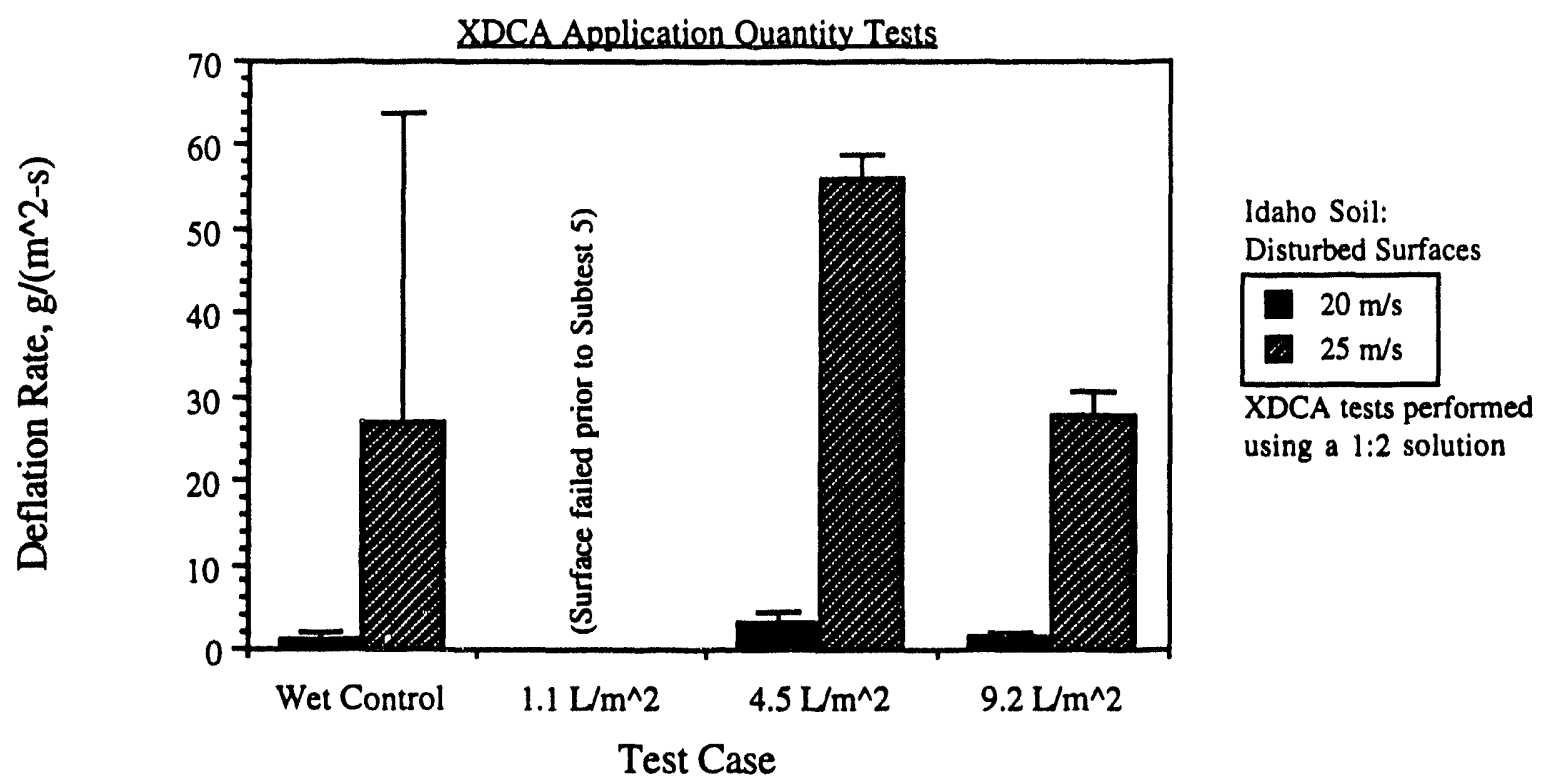

EIGURE 4.11 Disturbed Idaho Soil Protected by XDCA - Application Quantity Tests 


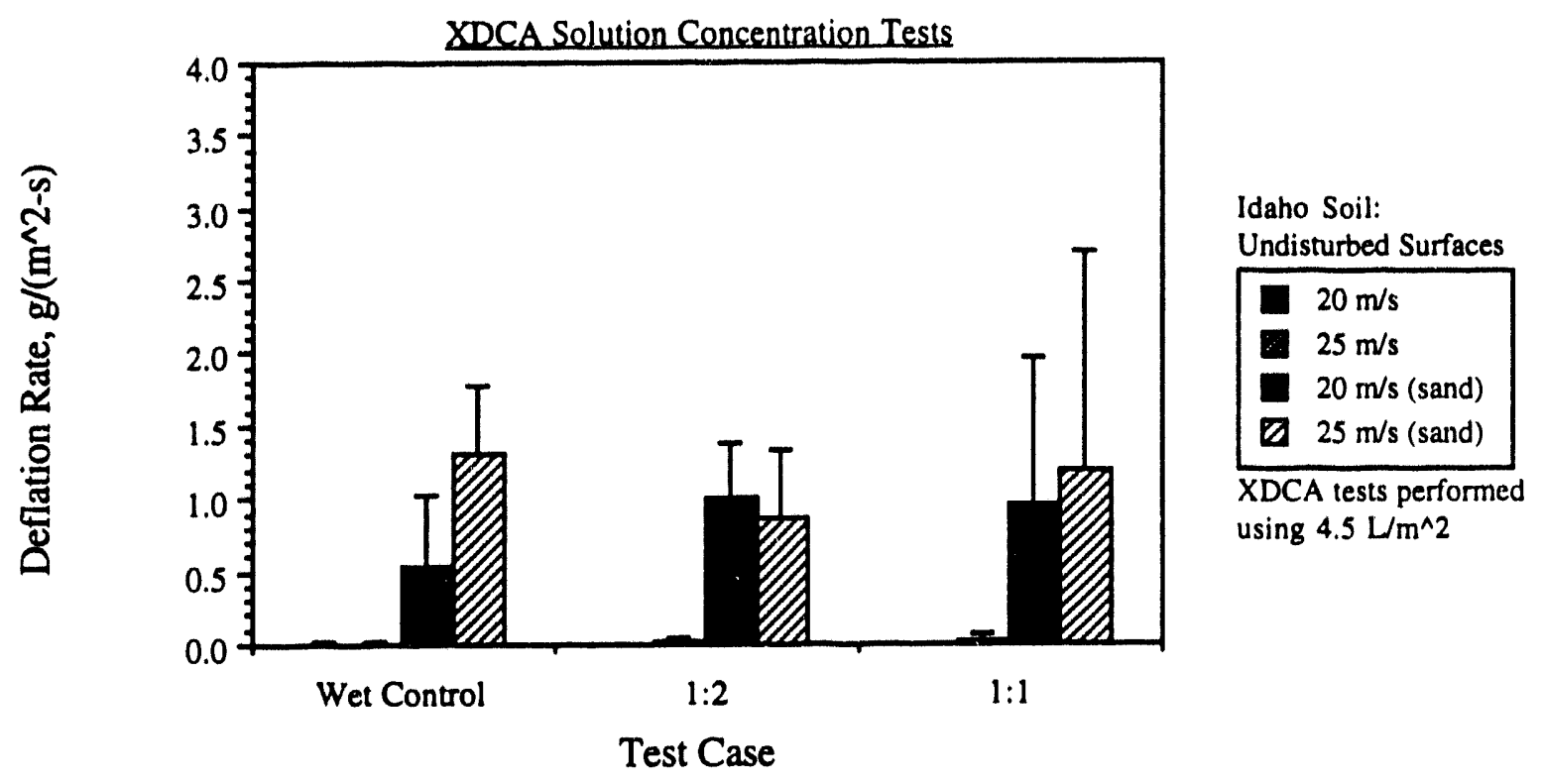

EIGURE 4.12 Undisturbed Idaho Soil Protected by XDCA - Solution Concentration Tests

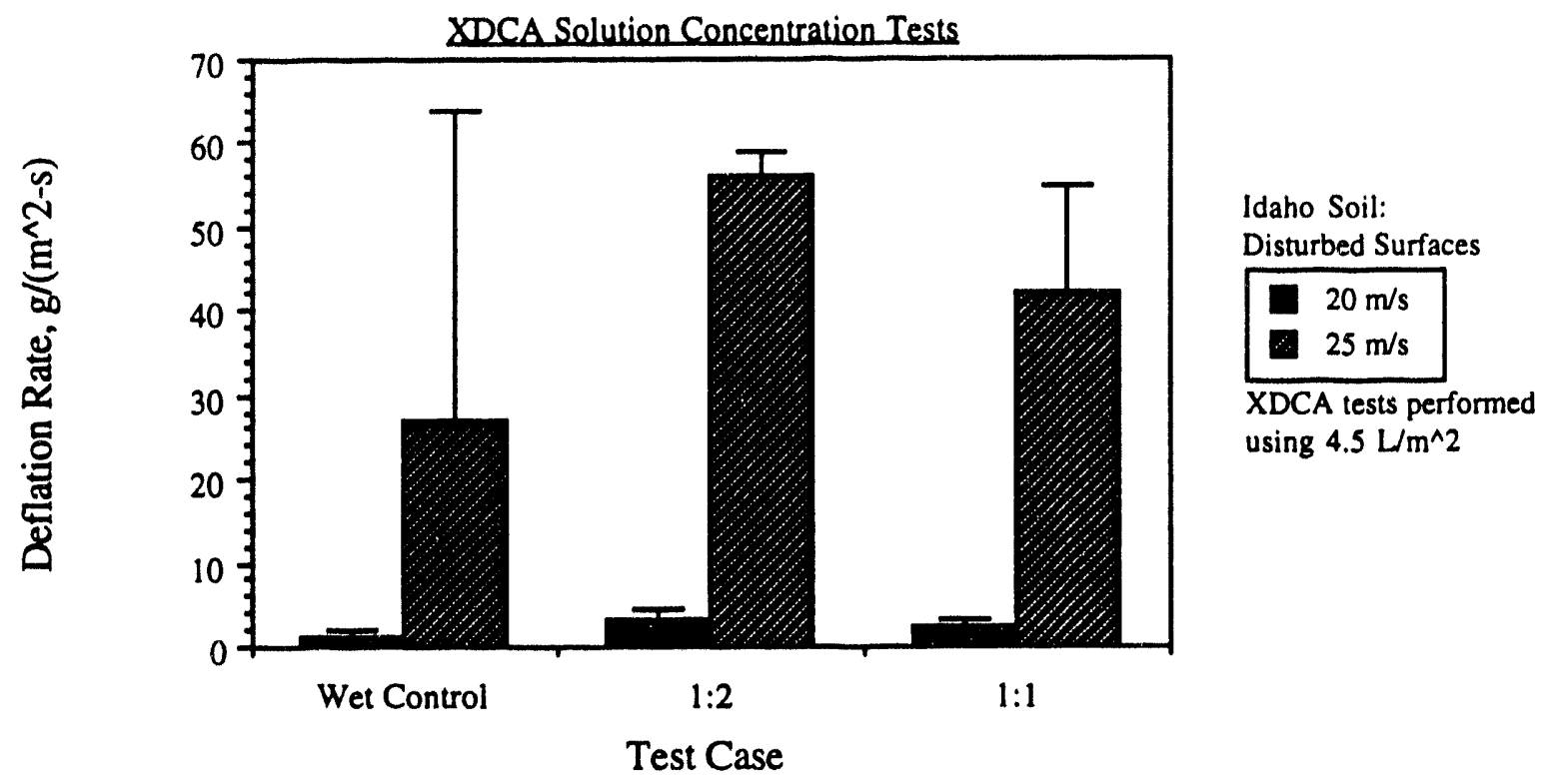

EIGURE 4.13 Disturbed Idaho Soil Protected by XDCA - Solution Concentration Tests 


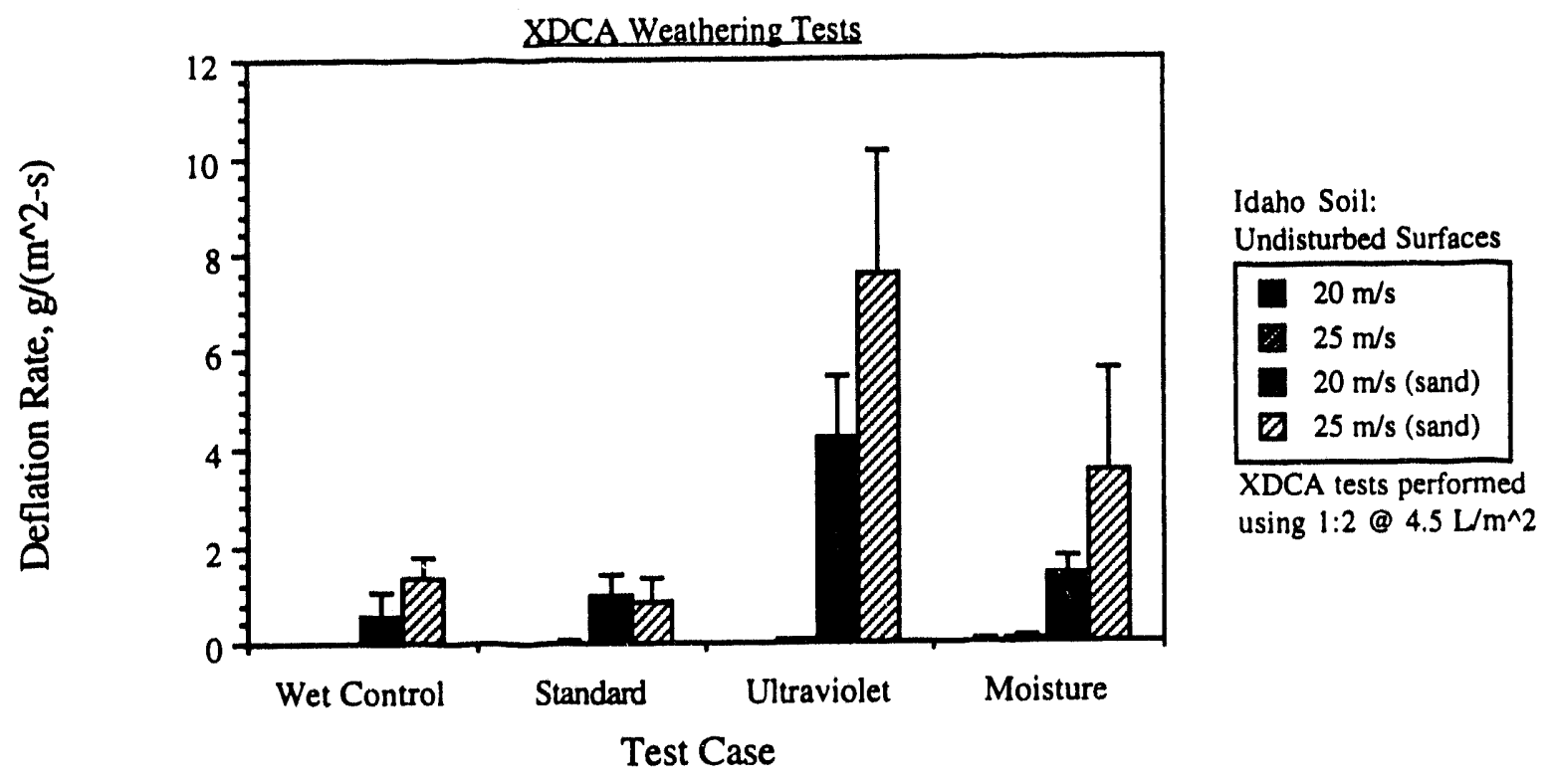

EIGURE 4.14 Influence of Aging Conditions on Undisturbed XDCA Crusts

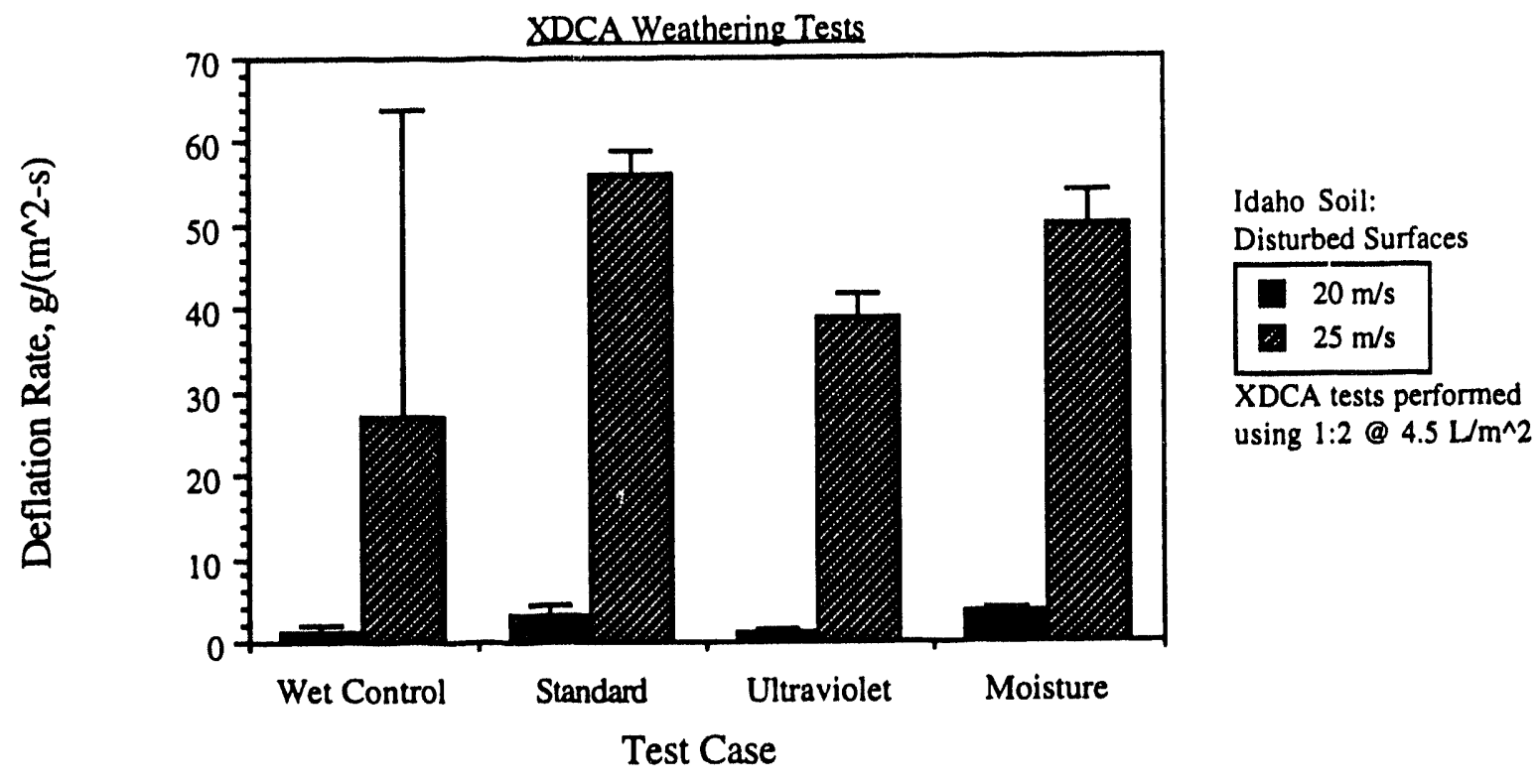

EIGURE 4.15 Influence of Aging Conditions on Disturbed XDCA Crusts 
of the undisturbed crusts; however, the results were not significantly different frcm the standard case. The disturbed crusts eroded similarly in all aging cases.

Table 4.3 shows a comparison of XDCA-treated to wet control Idaho soil surfaces by XDCA solution concentration and quantity applied. A general description of the table is provided in Section 4.3. The XDCA formed a superior surface crust only at a solution concentration of $1: 2$ and the highest application quantity of $9.2 \mathrm{~L} / \mathrm{m}^{2}$. Results of the other cases indicate that the water crust provided better protection. In particular, the $1: 2$ concentration, $1.1 \mathrm{~L} / \mathrm{m}^{2}$ case seemed to cause an increase in deflation rate.

\subsubsection{Fermented Potato Waste Surface Crusts}

Results discussed in this section refer to Idaho soil surfaces. Hanford soil surfaces protected by FPW solutions are discussed in Section 4.3.5. FPW surface crusts were prepared using four solution concentrations (1:9,1:4,1:2, and 1:1) and two application quantities (2 and 4 $\mathrm{L} / \mathrm{m}^{2}$ ). Solutions were prepared volumetrically as described in Section 3.3 and 4.1. Solution

TABLE 4.3 Ratio of Deflation Rates--XDCA Agent-Protected to Wet Control Surfaces, Idaho Soil Only. Data are listed as average, less than a maximum value, or average (range).

Subtest

Significant
Difference

Significant

No. Case $\quad 1.1 \mathrm{~L} / \mathrm{m}$

\begin{tabular}{|c|c|c|c|c|c|c|c|}
\hline \multicolumn{8}{|c|}{ 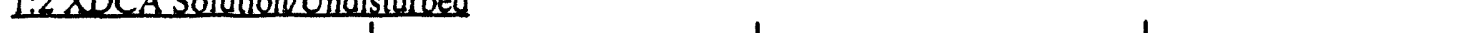 } \\
\hline 3 & $20 \mathrm{~m} / \mathrm{s}+\mathrm{sand}$ & $19(10-95)$ & (a) & $0.83(0.3-6)$ & no & $0.11(0-1.4)$ & no \\
\hline 4 & $25 \mathrm{~m} / \mathrm{s}+\mathrm{sand}$ & $33(21-62)$ & (a) & $0.72(0.2-2)$ & no & $0.013(0-0.13)$ & yes \\
\hline \multicolumn{8}{|c|}{ 1:2 XDCA Solution/Disturbed } \\
\hline 5 & $20 \mathrm{~m} / \mathrm{s}$ & $>1$ & (a) & $3.0(1-20)$ & no & $1.4(0.5-8)$ & no \\
\hline 6 & $25 \mathrm{~m} / \mathrm{s}$ & $>1$ & (a) & $1.9(0.9->1)$ & no & $0.97(0.4->1)$ & no \\
\hline 7 & $20 \mathrm{~m} / \mathrm{s}+\mathrm{sand}$ & -1 & no & -1 & no & $\mathbf{n} / \mathbf{a}$ & \\
\hline 8 & $25 \mathrm{~m} / \mathrm{s}+\mathrm{sand}$ & -1 & no & -1 & no & $<0.10$ & \\
\hline \multicolumn{8}{|c|}{ Lil XDCA Solution/Undisturbed } \\
\hline 3 & $20 \mathrm{~m} / \mathrm{s}+\mathrm{sand}$ & $\mathrm{n} / \mathrm{a}$ & & $0.81(0-8)$ & no & $\mathrm{n} / \mathrm{a}$ & \\
\hline 4 & $25 \mathrm{~m} / \mathrm{s}+\mathrm{sand}$ & $\mathrm{n} / \mathrm{a}$ & & $1.0(0-4)$ & no & $\mathrm{n} / \mathrm{a}$ & \\
\hline \multicolumn{8}{|c|}{ 1:1 XDCA Solution/Disturbed } \\
\hline 5 & $20 \mathrm{~m} / \mathrm{s}$ & $\mathrm{n} / \mathrm{a}$ & & $2.2(0.7-14)$ & no & $\mathrm{n} / \mathrm{a}$ & \\
\hline 6 & $25 \mathrm{~m} / \mathrm{s}$ & $\mathrm{n} / \mathrm{a}$ & & $1.5(0.5->1)$ & no & $\mathrm{n} / \mathrm{a}$ & \\
\hline 7 & $20 \mathrm{~m} / \mathrm{s}+\mathrm{sand}$ & $\mathrm{n} / \mathrm{a}$ & & & yes & $\mathrm{n} / \mathrm{a}$ & \\
\hline & $25 \mathrm{~m} / \mathrm{s}+\mathrm{sand}$ & $\mathrm{n} / \mathrm{a}$ & & $<0.22$ & yes & $\mathrm{n} / \mathrm{a}$ & \\
\hline
\end{tabular}

(a) Significant difference, XDCA-coated surfaces less protected than wet control surfaces. 
concentrations $1: 9,1: 4,1: 2$, and $1: 1$ represent $10,20,33$, and $50 \%$ FPW in water, respectively. Tests were performed of the $1: 4$ at $2 \mathrm{~L} / \mathrm{m}^{2}$ and all $4 \mathrm{~L} / \mathrm{m}^{2}$ cases. Based on early results, the "standard" case was selected to be 1:4 at $4 \mathrm{~L} / \mathrm{m}^{2}$. This case was used to test the impact of surface aging conditions (uv-cycle and moisture-cycle). Solution concentrations of $1: 1$, and to a lesser extent 1:2, formed heavily cracked surfaces similar to a dried lake bottom. While the other dust control agents also formed lightly cracked surfaces, these cases were the only ones that formed crusts so heavy that the crust plates curled up at the edges. One result of this was a susceptibility to erosion as wind was able to apply force to the exposed edges. It is possible that a modified solution would prevent this occurrence.

The FPW provided protection of undisturbed surfaces for certain combinations of solution concentration and application quantity. Disturbed surfaces were not significantly protected. Application of FPW at $4 \mathrm{~L} / \mathrm{m}^{2}$ performed better than that of $2 \mathrm{~L} / \mathrm{m}^{2}$ for the single solution concentration tested (1:4) and undisturbed surfaces. However, both application quantities performed similarly to the wet controls after the surfaces were disturbed. These results are shown in Figures 4.16 and 4.17. Applications of low and medium solution concentrations of FPW performed better than the highest concentration, as shown in Figure 4.18, simply because the heavily cracked surface resulting from the 1:1 application was susceptible to losing crust plates. As shown in Figure 4.19, FPW did not significantly protect the disturbed surfaces regardless of solution concentration. Figures 4.20 and 4.21 show the impact of surface aging on surface protection by FPW. As with the PS fixative, surface protection was lost with exposure to moisture-cycling, but exposure to uv-cycling did not significantly degrade surface protection.

Table 4.4 shows a comparison of FPW-treated to wet control Idaho soil surfaces by FPW solution concentration and quantity applied. A general description of the table is provided in Section 4.3. The 1:2 and 1:1 solution concentration cases were not included in the table because no replicate tests were performed. The FPW generally provided better surface protection; however, because of uncertainties in the wet controls, significant differences were not measured in some cases.

\subsubsection{Impact of Soil Type on Surface Protection}

Although a majority of tests were performed using Idaho soil, it was recognized that the much different structure of the Hanford soil could impact the suitability of dust control agents. This presumption was based on the potential for different wetability and penetrability of the agents into the different soil surfaces. The Idaho soil appeared to contain more loam and the Hanford soil clearly contained more sand and was more coarsely grained. Two replicate tests were therefore 


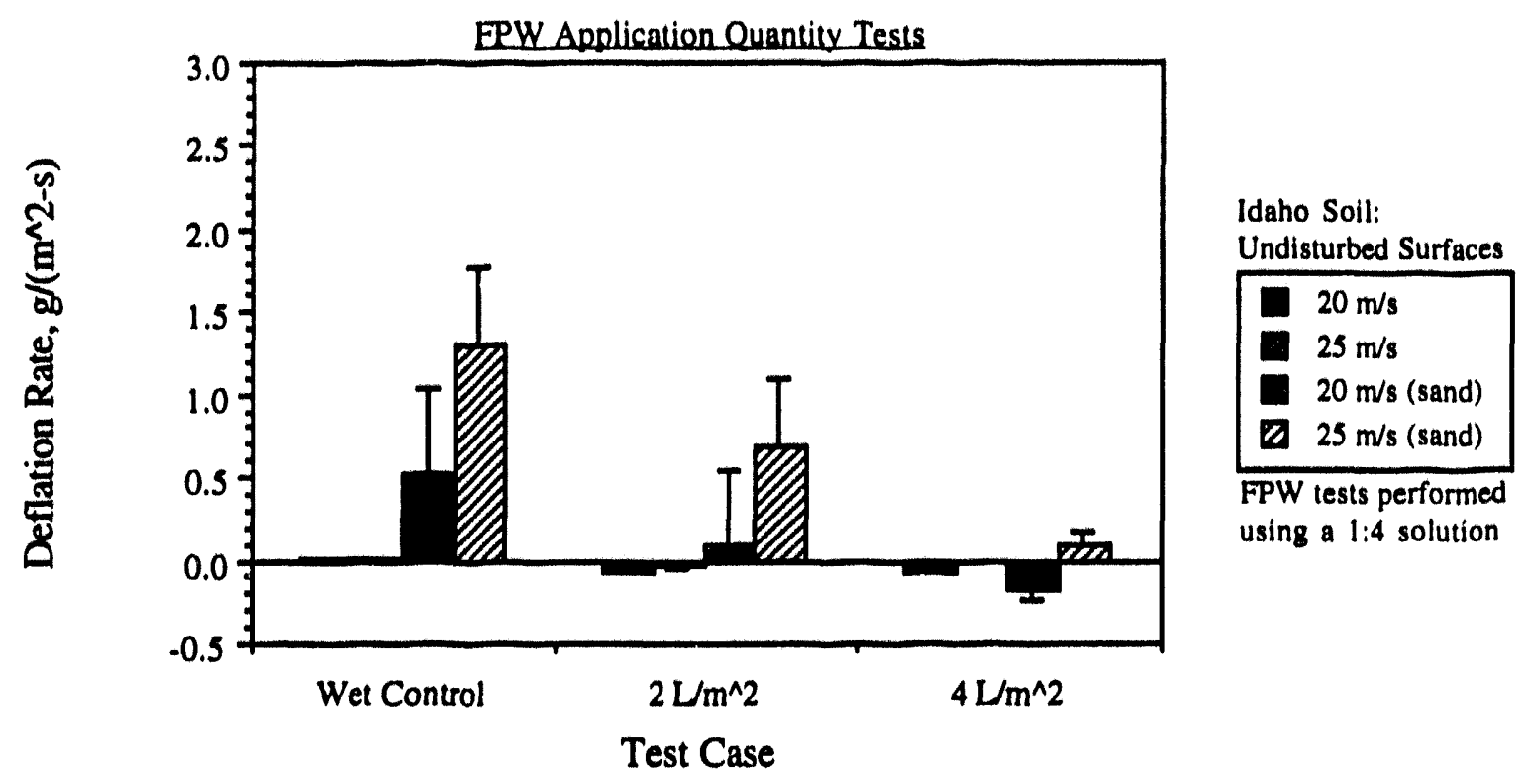

EIGURE 4.16 Undisturbed Idaho Soil Protected by FPW - Application Quantity Tests

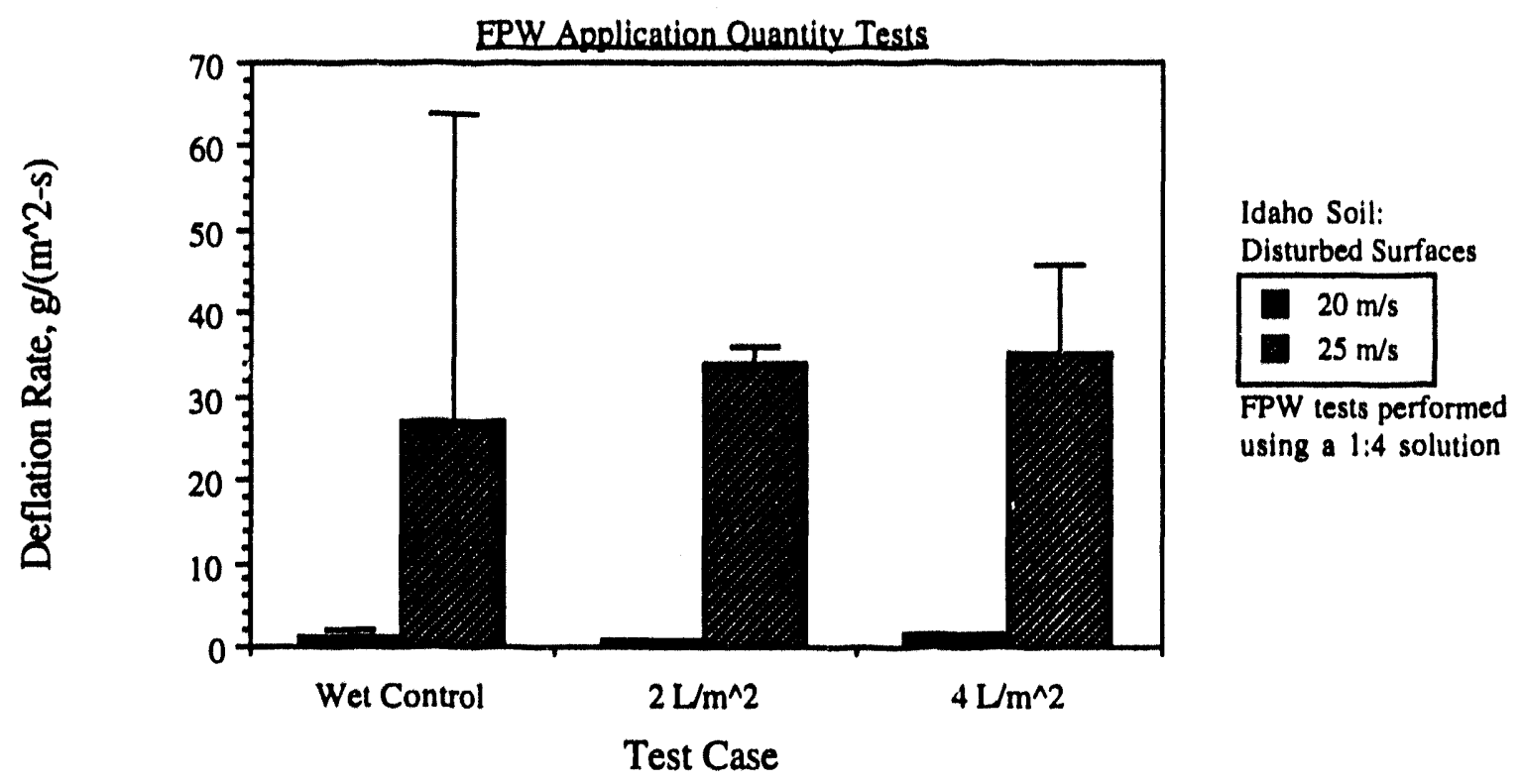

EIGURE 4.17 Disturbed Idaho Soil Protected by FPW - Application Quantity Tests 


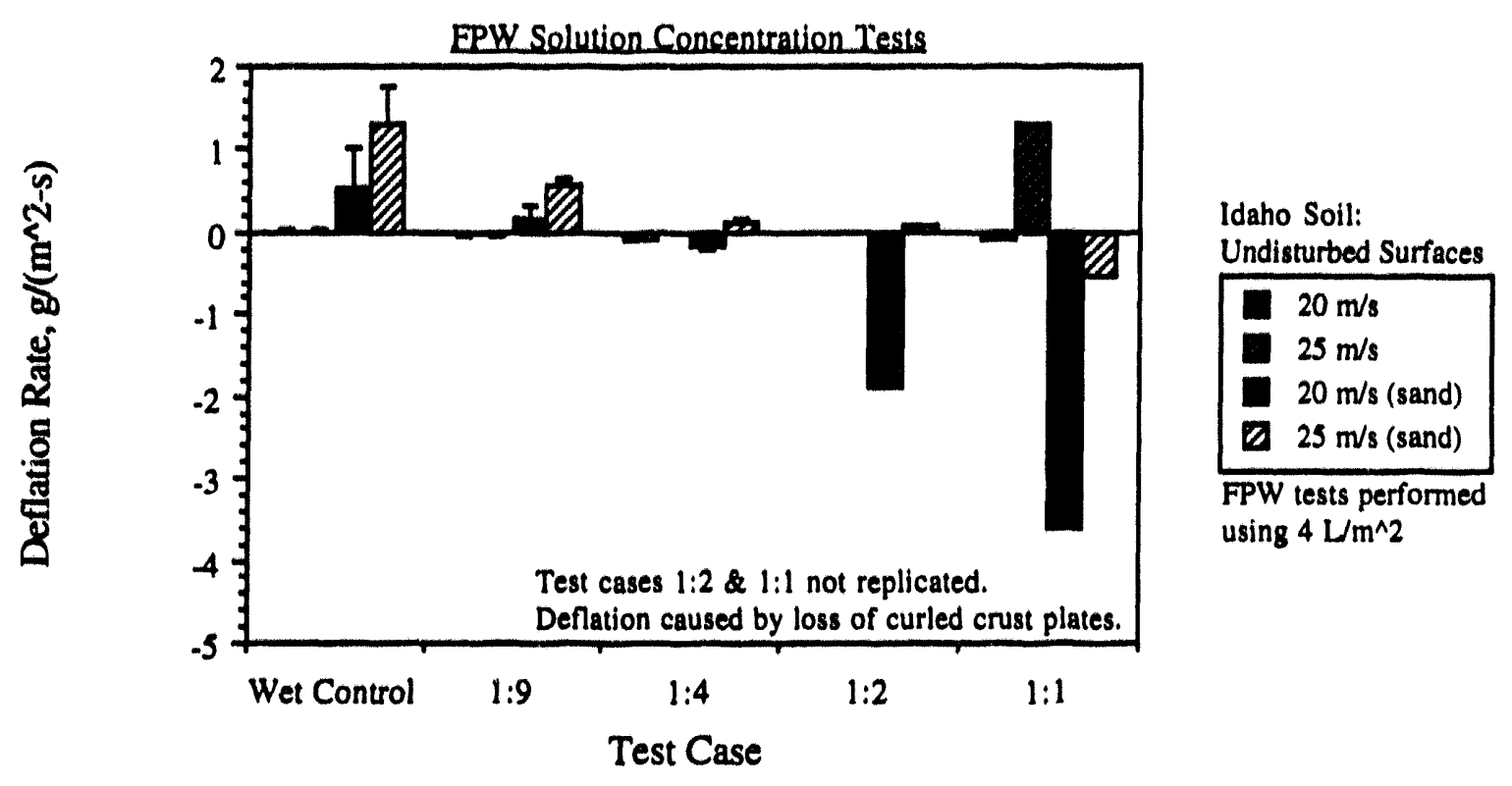

EIGURE 4.18 Undisturbed Idaho Soil Protected by FPW - Solution Concentration Tests

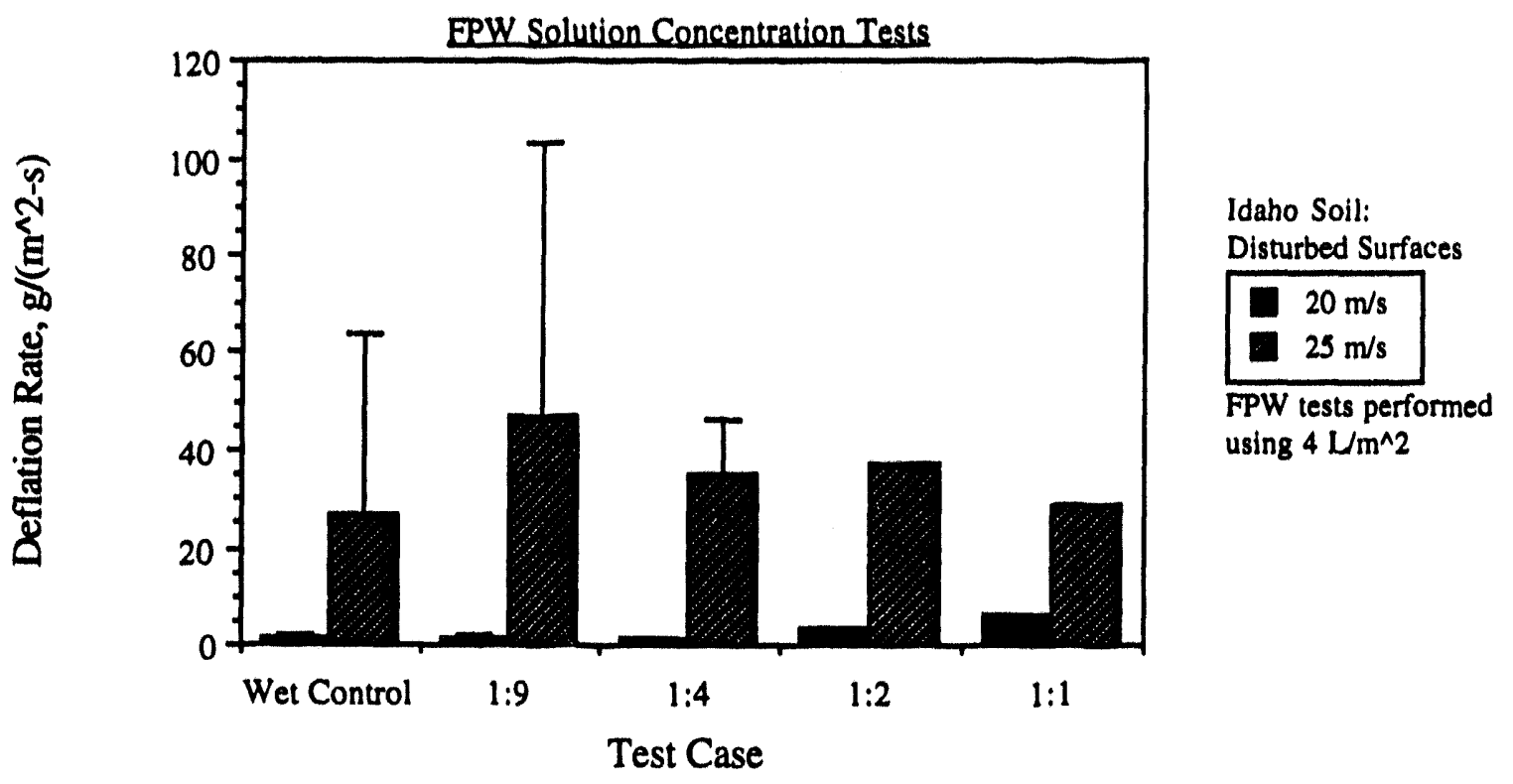

EIGURE 4.19 Disturbed Idaho Soil Protected by FPW - Solution Concentration Tests 


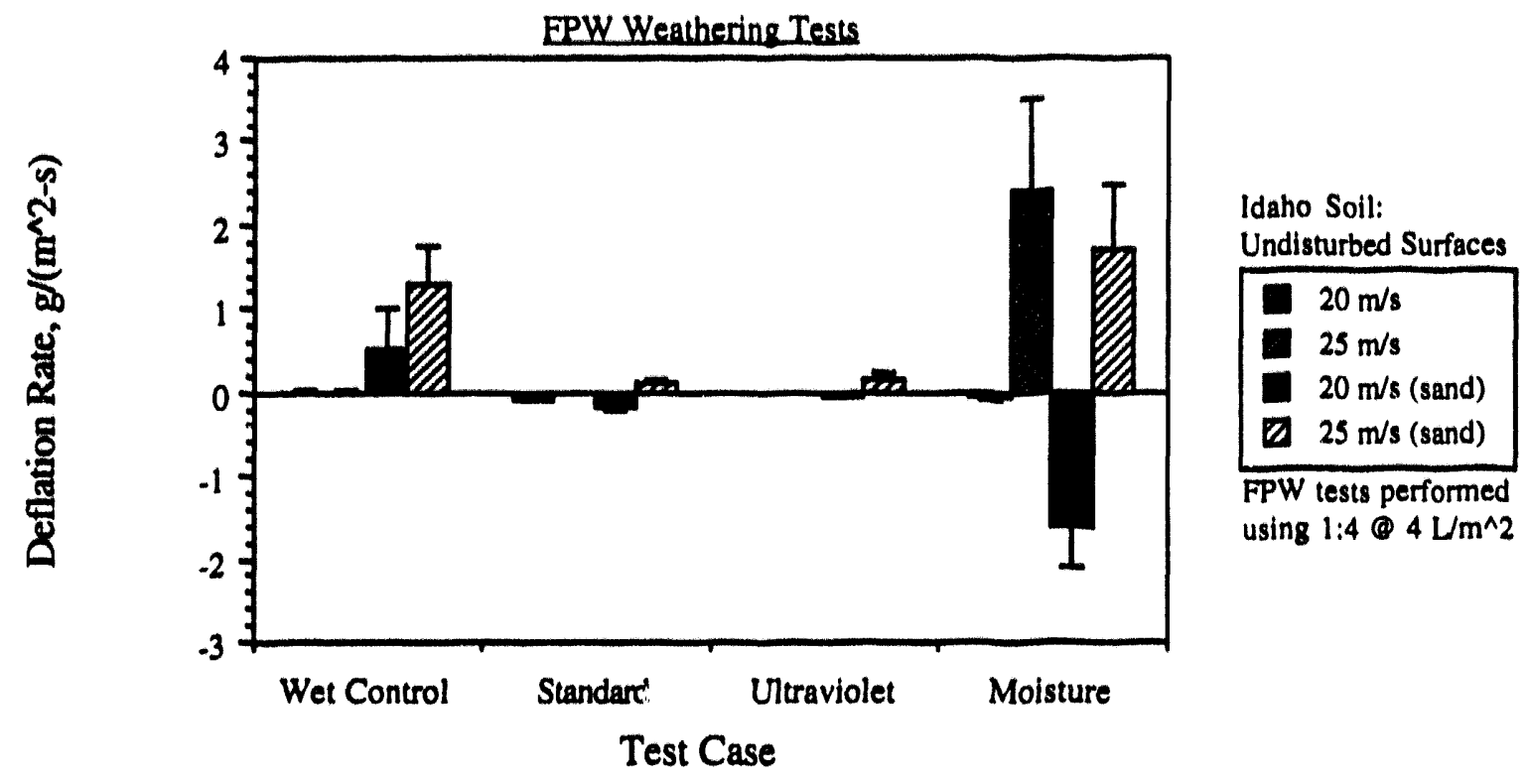

EIGURE 4.20 Influence of Aging Conditions on Undisturbed FPW Crusts

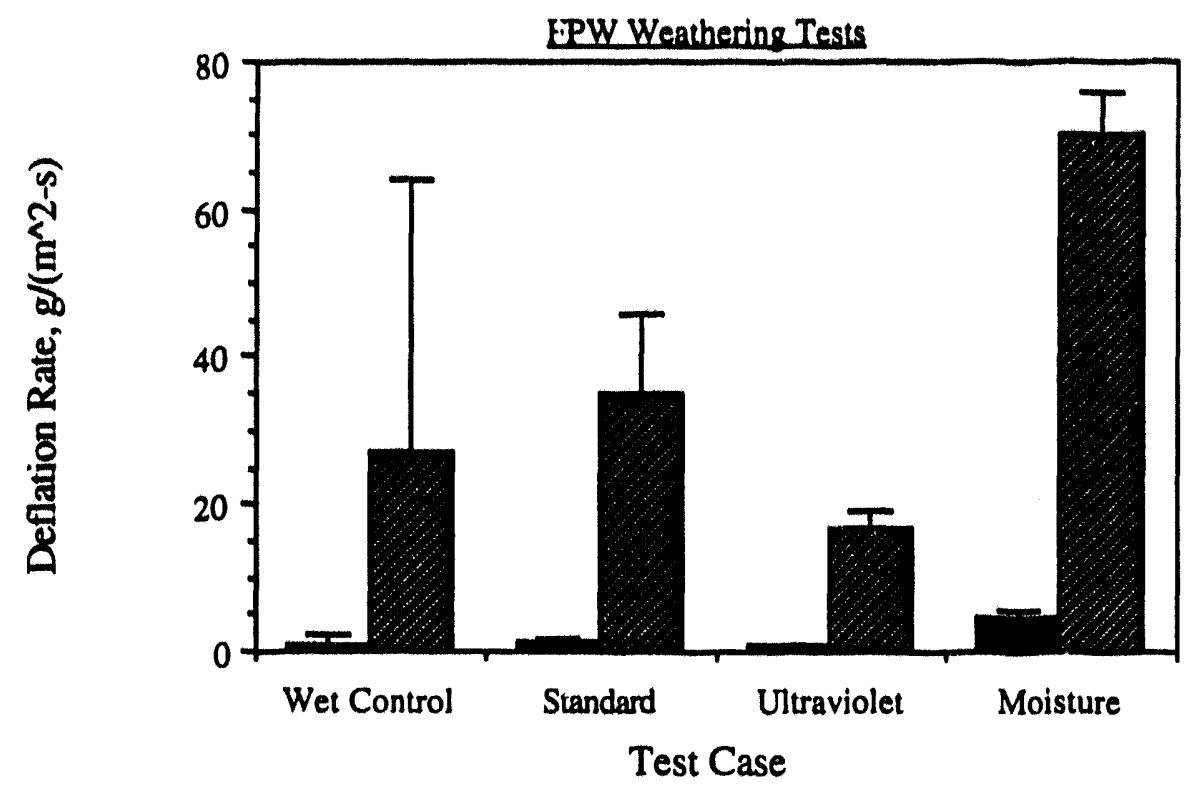

Idaho Soil: Disturbed Surfaces

D. $20 \mathrm{~m} / \mathrm{s}$
$25 \mathrm{~m} / \mathrm{s}$

FPW tests performed using 1:4 $4 \mathrm{~L} / \mathrm{m}^{\wedge} 2$

EIGURE 4.21 Influence of Aging Conditions on Disturbed FPW Crusts 
TABLE 4.4 Ratio of Deflation Rates--FPW Agent-Protected to Wet Control Surfaces. Idaho soil only. Data are listed as average, less than a maximum value, or average (range).

\begin{tabular}{|c|c|c|c|c|c|c|c|c|}
\hline $\begin{array}{l}\text { Subtest } \\
\text { Ne. }\end{array}$ & Case & $1 \mathrm{~L} / \mathrm{m}^{2}$ & $\begin{array}{l}\text { Significant } \\
\text { Difference }\end{array}$ & $2 \mathrm{~L} / \mathrm{m}^{2}$ & $\begin{array}{l}\text { ificant } \\
\text { erence }\end{array}$ & $4 \mathrm{~L} / \mathrm{m}^{2}$ & $\begin{array}{l}\text { Signif } \\
\text { Differ }\end{array}$ & $\begin{array}{l}\text { iicant } \\
\text { rence }\end{array}$ \\
\hline 1:2EPW & W Solution/Und & urbed & & & & & & \\
\hline $\begin{array}{l}3 \\
4\end{array}$ & $\begin{array}{l}20 \mathrm{~m} / \mathrm{s}+\text { sand } \\
25 \mathrm{~m} / \mathrm{s}+\text { sand }\end{array}$ & $\begin{array}{l}n / a \\
n / a\end{array}$ & & $\begin{array}{l}n / a \\
n / a\end{array}$ & & $\begin{array}{l}0.13(1 \\
0.48(0 .\end{array}$ & $\begin{array}{l}1.2) \\
3-0.97)\end{array}$ & $\begin{array}{l}\sim \text { no } \\
\text {-yes }\end{array}$ \\
\hline L.9 EPW & W Solution/Dis & bed & & & & & & \\
\hline $\begin{array}{l}5 \\
6 \\
7 \\
8\end{array}$ & $\begin{array}{l}20 \mathrm{~m} / \mathrm{s} \\
25 \mathrm{~m} / \mathrm{s} \\
20 \mathrm{~m} / \mathrm{s}+\text { sand } \\
25 \mathrm{~m} / \mathrm{s}+\text { sand }\end{array}$ & $\begin{array}{l}n / a \\
n / a \\
n / a \\
n / a\end{array}$ & & $\begin{array}{l}n / a \\
n / a \\
n / a \\
n / a\end{array}$ & & $\begin{array}{l}1.0(0.0 \\
1.6(0-> \\
-1 \\
-1\end{array}$ & & $\begin{array}{l}\text { no } \\
\text { no } \\
\text { no } \\
\text { no }\end{array}$ \\
\hline L:4 EPW & $N$ Solution/Un & urbed & & & & & & \\
\hline $\begin{array}{ll}3 & 2 \\
4 & 2\end{array}$ & $\begin{array}{l}20 \mathrm{~m} / \mathrm{s}+\text { sand } \\
25 \mathrm{~m} / \mathrm{s}+\text { sand }\end{array}$ & $\begin{array}{l}n / a \\
n / a\end{array}$ & & $\begin{array}{l}0.092(0-2) \\
0.58(0.2-1.7)\end{array}$ & $\begin{array}{l}\text { no } \\
\text { no }\end{array}$ & $\stackrel{-0}{0.092(C}^{-0}$ & $.02-0.3)$ & $\begin{array}{l}\text { yes } \\
\text { yes }\end{array}$ \\
\hline $1: 4$ EPW & $N$ Solution/Dis & & & & & & & \\
\hline $\begin{array}{l}2 \\
2 \\
2 \\
2\end{array}$ & $\begin{array}{l}20 \mathrm{~m} / \mathrm{s} \\
25 \mathrm{~m} / \mathrm{s} \\
20 \mathrm{~m} / \mathrm{s}+\text { sand } \\
25 \mathrm{~m} / \mathrm{s}+\text { sand }\end{array}$ & $\begin{array}{l}n / a \\
n / a \\
n / a \\
n / a\end{array}$ & & $\begin{array}{l}0.71(0.4-3) \\
1.2(0.5->1) \\
-0 \\
<0.24\end{array}$ & $\begin{array}{l}\text { no } \\
\text { no } \\
\text { yes } \\
\text { yes }\end{array}$ & $\begin{array}{l}1.4(0.7 \\
1.2(0.4 \\
\sim 1 \\
\sim 1\end{array}$ & $\begin{array}{l}\text { 7) } \\
>1)\end{array}$ & $\begin{array}{l}\text { no } \\
\text { no } \\
\text { no } \\
\text { no }\end{array}$ \\
\hline
\end{tabular}

performed on Hanford soil using the standard application rate for each of the three dust control agents. Tests of dry and wet controls were also performed for comparison. As shown in Section 4.3.1, the unprotected dry and wet control Hanford soil surfaces were significantly more susceptible to erosion by wind than were the other two soil types (dry and wet controls of McGee Ranch silt-loam were also tested). Based on the $20 \mathrm{~m} / \mathrm{s}+10 \mathrm{~kg}$ sand case (Subtest 3), erosion by wind of wet control Hanford soil was about 14-fold greater than that of McGee Ranch soil and about 170-fold greater than Idaho soil. Tests were performed using dry controls, wet controls (2 $\mathrm{L} / \mathrm{m}^{2}$ water), PS ( $1 \%$ solution at $\left.2 \mathrm{~L} / \mathrm{m}^{2}\right), X D C A\left(1: 2\right.$ solution at $\left.4.5 \mathrm{~L} / \mathrm{m}^{2}\right)$, and FPW (1:4 solution at $4 \mathrm{~L} / \mathrm{m}^{2}$ ). Only Batch 1 , wet Idaho soil controls, was considered.

Results of these single-treatment tests clearly indicate that the differences between the two soils did indeed significantly alter the protection provided by the dust control agents. Figures 4.22 through 4.24 show measured surface deflation rates for both soil types and each dust control agent. The PS provided protection of both undisturbed and disturbed Idaho soil surfaces. In the figures, deflation rates equal to or exceeding $100 \mathrm{~g} /\left(\mathrm{m}^{2}-\mathrm{s}\right)$ indicate that surface protection failed at that condition. The XDCA did not protect Idaho soil surfaces. The FPW protected only undisturbed Idaho soil surfaces. However, an entirely different result occurred for the highly 


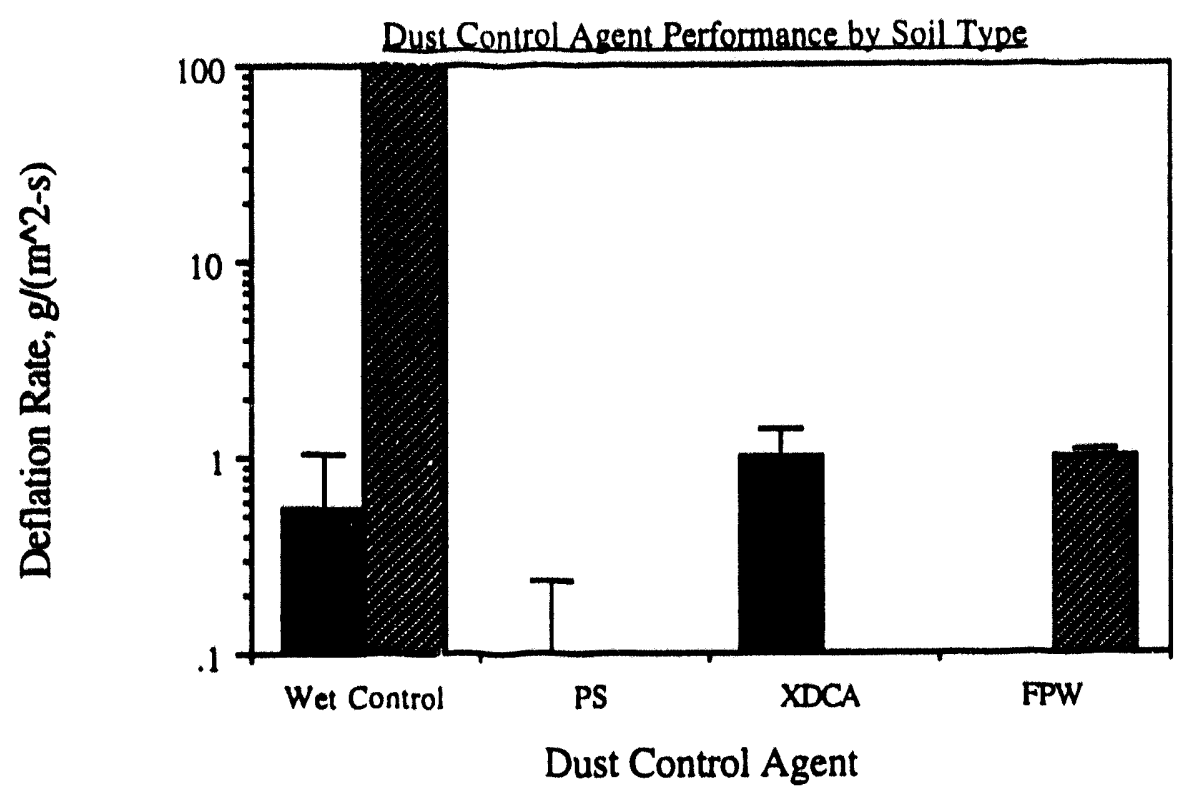

Subtest 3

Undisturbed

$20 \mathrm{in} / \mathrm{s}$, sand

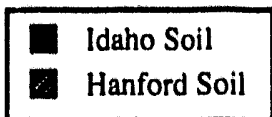

Control $-2 \mathrm{~L} / \mathrm{m}^{\wedge} 2 \mathrm{H} 2 \mathrm{O}$

PS - $1 \%$ @ $2 \mathrm{~L} / \mathrm{m}^{\wedge} 2$

$\mathrm{XDCA}-1: 2 @ 4.5 \mathrm{~L} / \mathrm{m}^{\wedge} 2$

FPW $\cdot 1: 4 @ 4 \mathrm{~L} / \mathrm{m}^{\wedge} 2$

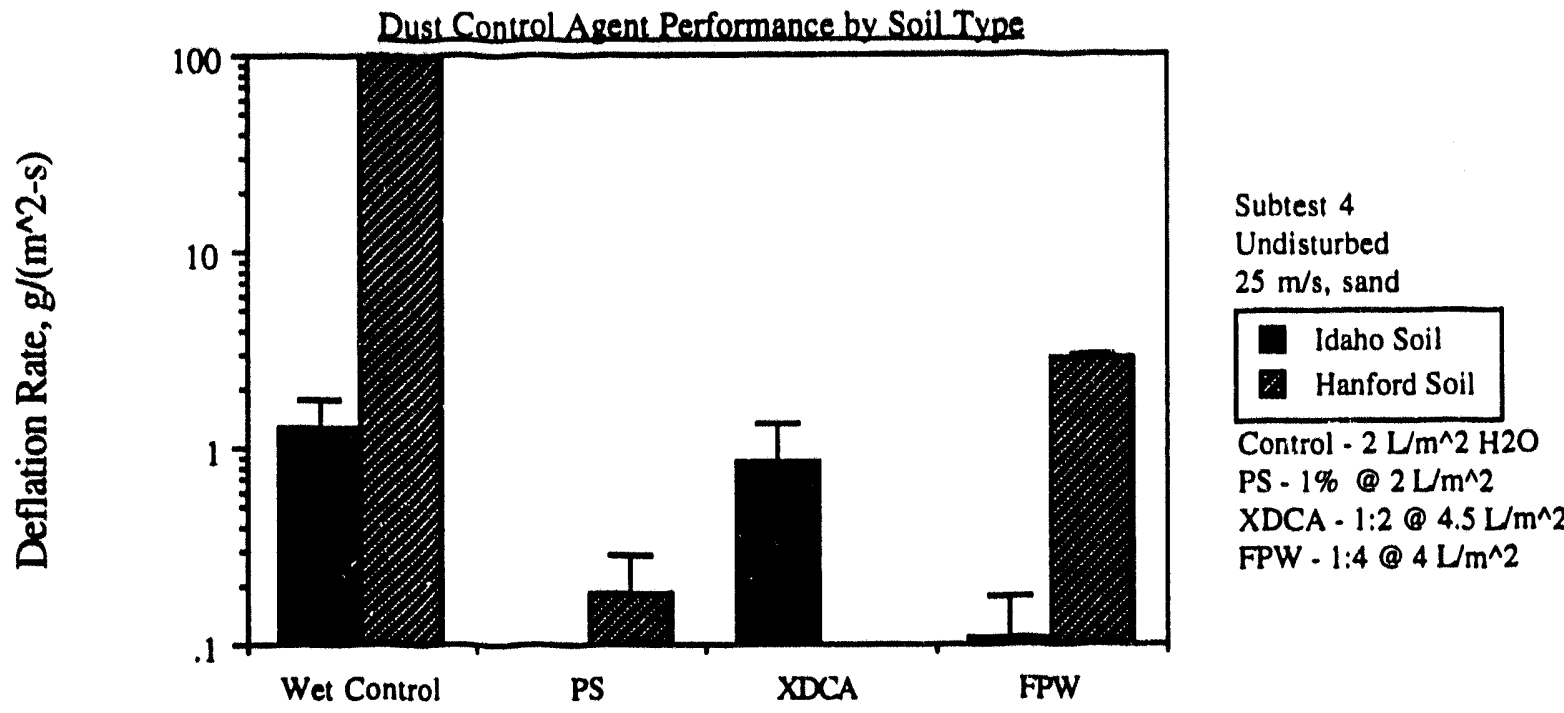

FIGURE 4.22 Surface Deflation Rates Measured from Undisturbed (Wind and Saltating Sand) Idaho and Hanford Soils Protected by PS, XDCA, and FPW Dust Control Agents. Wet controls provided for information, rates $\geq 100 \mathrm{~g} /\left(\mathrm{m}^{2-}\right.$ s) indicate failure of surface protection. 


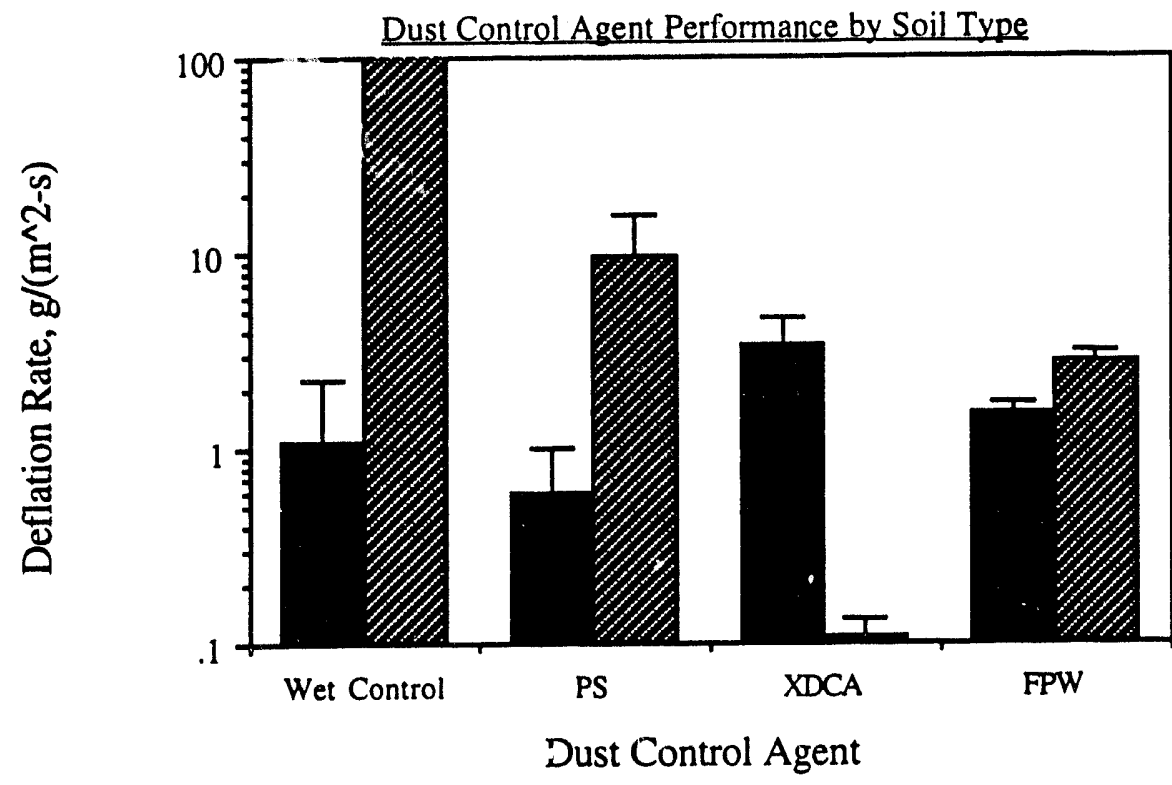

Subtest 5

Disturbed

$20 \mathrm{~m} / \mathrm{s}$, no sand

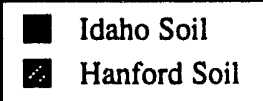

Control - $2 \mathrm{~L} / \mathrm{m}^{\wedge} 2 \mathrm{H} 2 \mathrm{O}$

PS - $1 \% @ 2 \mathrm{~L} / \mathrm{m}^{\wedge} 2$

$\mathrm{XDCA}-1: 2 @ 4.5 \mathrm{~L} / \mathrm{m}^{\wedge} 2$

FPW-1:4@4 L/m^2

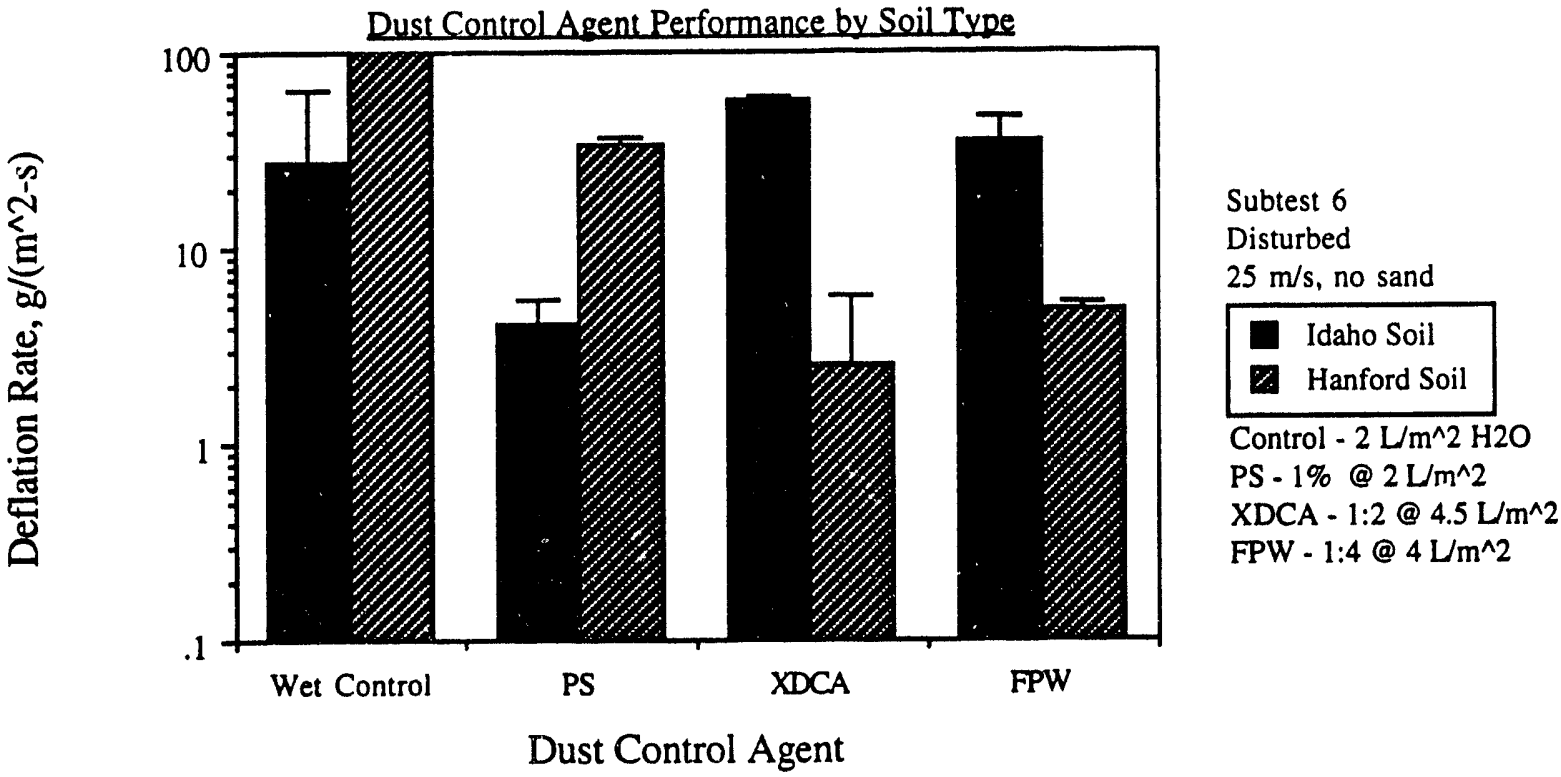

FIGURE 4.23 Surface Deflation Rates Measured from Disturbed (Wind Only) Idaho and Hanford Soils Protected by PS, XDCA, and FPW Dust Control Agents. Wet controls provided for information, rates $\geq 100 \mathrm{~g} /\left(\mathrm{m}^{2}-\mathrm{s}\right)$ indicate failure of surface protection. 

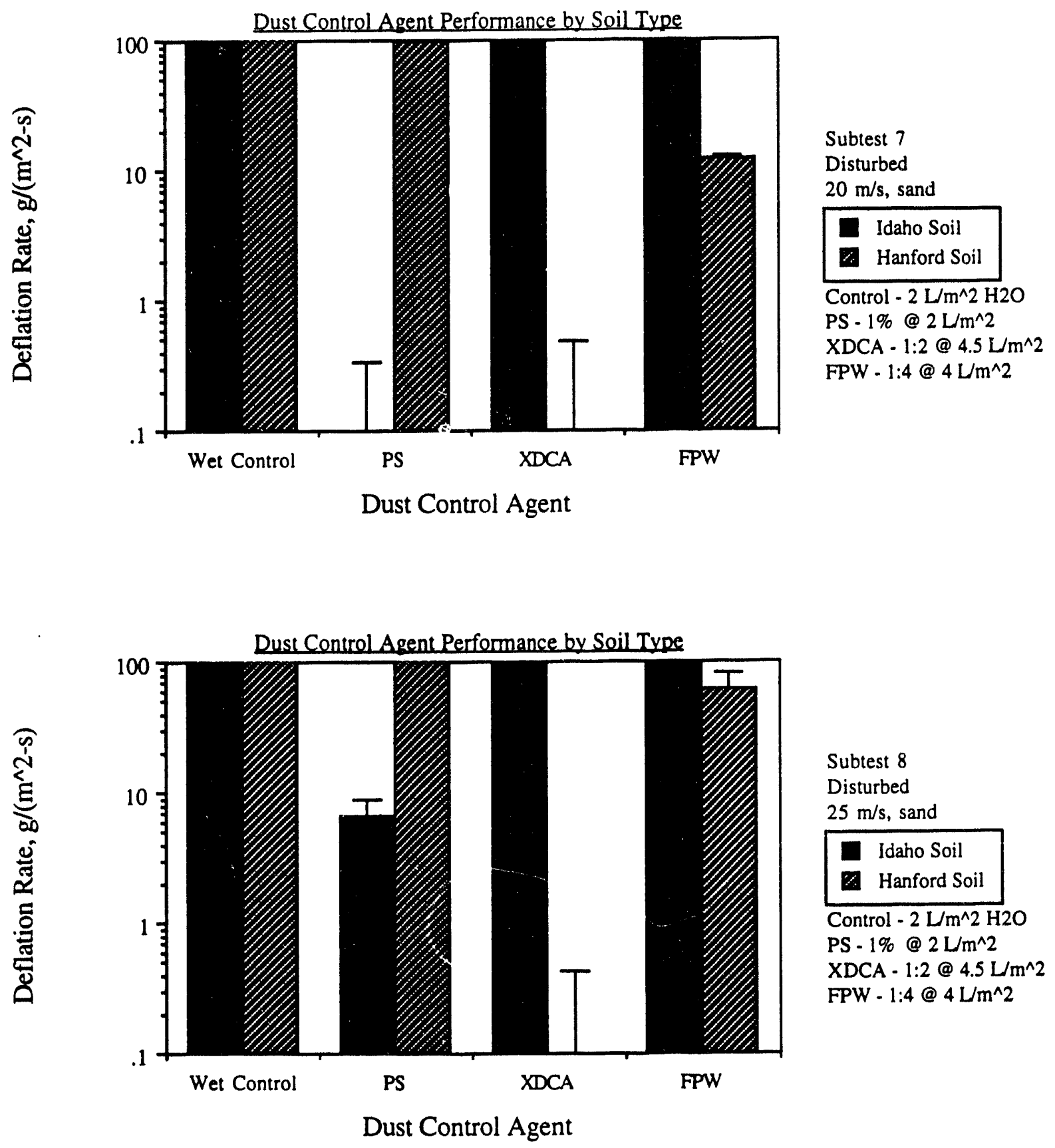

FIGURE 4.24 Surface Deflation Rates Measured from Disturbed (Wind and Saltating Sand) Idaho and Hanford Soils Protected by PS, XDCA, and FPW Dust Control Agents. Wet controls provided for information, rates $\geq 100 \mathrm{~g} / \mathrm{m}^{2}$ s) indicate failure of surface protection. 
erodible Hanford soil. The PS provided limited protection of undisturbed and disturbed Hanford soil surfaces. The XDCA clearly provided nearly ideal protection of the sandy Hanford soil. This protection was less than perfect only during the disturbed surface, $25 \mathrm{~m} / \mathrm{s}$, no-sand case (Subtest 6). However, after stabilizing during that subtest, XDCA-protected Hanford soil surfaces again became nearly perfectly resistant to erosion during subsequent disturbed surface tests with saltating sand stresses. Additionally, in extended tests performed using one disturbed surface (Test 65a), the XDCA-protected Hanford soil remained intact even after several days additional aging unde * laboratory conditions. After additional post-test moisture-cycling of this twice-tested and disturbed case (Test 65b), the surface continued to perform very well, although some minor deflation losses did finally occur during subtests 5 and 8. FPW provided an intermediate level of protection of both undisturbed and disturbed Hanford soil surfaces. In all undisturbed surface cases, PS was better than FPW. In all disturbed surface cases, FPW was better than PS.

Table 4.5 compares of the various dust control agents by soil type and subtest. A general description of the table is provided in Section 4.3. Idaho soil surfaces were protected by PS other than during Subtests 5 and 6, were not protected by XDCA, and were protected by FPW only during Subtests 3 and 4. In contrast, Hanford soil surfaces were protected through Subtest 6 by PS and through all subtests by XDCA and FPW. Noting the ratio of deflation rates shown in the table, it is clear that XDCA provides the best protection of Hanford soil surfaces; deflation rates from the XDCA-protected surfaces never exceeded, and were generally much less than $5 \%$ of those from the wet control, while the rates from the FPW-protected surface less than 3,5,13, and $82 \%$ of the wet control for the disturbed surface case (Subtests $5,6,7$, and 8 , respectively). 
TABLE 4.5. Ratio of Deflation Rates --Agent-Protected to Wet Control Surfaces.

Comparison of soil types. Data are listed as average, less than a maximum value, or average (range).

Subtest

No. Case

Significant Difference

XDCA $\begin{aligned} & \text { Significant } \\ & \text { Difference }\end{aligned}$

Significant

Idahe Soil/Undisturbed

$320 \mathrm{~m} / \mathrm{s}+$ sand

$425 \mathrm{~m} / \mathrm{s}$ + sand

PS

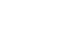

Idahe Soil/Disturbed

$520 \mathrm{~m} / \mathrm{s}$

$625 \mathrm{~m} / \mathrm{s}$

$720 \mathrm{~m} / \mathrm{s}+$ sand

$825 \mathrm{~m} / \mathrm{s}+$ sand

Hanford Soil/Undisturbed

$320 \mathrm{~m} / \mathrm{s}+$ sand

$425 \mathrm{~m} / \mathrm{s}+$ sand

Hanford SoillDisturbed

$5 \quad 20 \mathrm{~m} / \mathrm{s}$

$6 \quad 25 \mathrm{~m} / \mathrm{s}$

$7 \quad 20 \mathrm{~m} / \mathrm{s}+$ sand

$825 \mathrm{~m} / \mathrm{s}+$ sand

\begin{tabular}{ll|l}
$\sim 0$ & yes & $0.83(0.3-6)$ \\
-0 & yes & $0.72(0.2-2)$ \\
& & \\
$0.53(0.07-4)$ & no & $3.0(1-20)$ \\
$0.14(0.05->1)$ & no & $1.9(0.9->1)$ \\
$\sim 0$ & yes & $\sim 1$ \\
$<0.08$ & yes & $\sim 1$ \\
& & \\
& & \\
$\sim 0$ & yes & -0 \\
$<0.003$ & yes & -0 \\
& & \\
& & \\
$<0.16$ & yes & $<0.001$ \\
$<0.37$ & yes & $<0.05$ \\
$\sim 1$ & no & -0 \\
$\sim 1$ & no & -0
\end{tabular}

\begin{tabular}{l|ll} 
no & -0 & yes \\
no & $0.092(0.02-0.3)$ & yes \\
& & \\
no & $1.4(0.7-7)$ & no \\
no & $1.2(0.4->1)$ & no \\
no & -1 & no \\
no & $\sim 1$ & no \\
& & \\
yes & $<0.005$ & yes \\
yes & $<0.03$ & yes \\
& & \\
yes & $<0.03$ & yes \\
yes & $<0.05$ & yes \\
yes & $<0.13$ & yes \\
yes & $<0.82$ & yes
\end{tabular}




\subsection{CONCLUSIONS AND RECOMMENDATIONS}

A series of 69 wind tunnel tests were performed and provided data for comparing the effectiveness of three fugitive dust suppressant agents to protect a loamy Idaho soil subjected to eolian stresses. A small number of tests were also performed that permitted comparison of these products on a sandy Hanford soil. Test parameters included soil and dust control agent type, solution concentrations, application quantities, aging (or drying) conditions, surface disturbance, and wind and saltating sand eolian erosive stresses that were selected and controlled to simulate application and exposure of excavated soil surfaces in the field. Test procedures were modifications of those described by Ligotke (1993). It should be noted that the deflation rates reported were averaged over the durations of the subtests (generally $2.0 \mathrm{~min}$ ). Because the rate of loss typically decreased with time as erodible elements were removed, these results represent initial, or worst-case, conditions. In the field, actual deflation rates would be expected to decrease with time until the crusts fail, after which rates would increase and eventually return to those typical of unprotected surfaces.

Quantification of surface shear stresses applied to the surfaces were based on the previous work and on measurements performed during the present study. Friction velocities applied to the undisturbed surfaces were about 1.1 and $1.4 \mathrm{~m} / \mathrm{s}$ at wind tunnel wind speeds of 20 and $25 \mathrm{~m} / \mathrm{s}$, respectively. Friction velocities applied to the disturbed surfaces were 1.76 and $2.1 \mathrm{~m} / \mathrm{s}$ at wind tunnel wind speeds of 20 and $25 \mathrm{~m} / \mathrm{s}$, respectively. The mass flow rates of saltating sand in the present study were 170 and $250 \mathrm{~g} /\left(\mathrm{m}^{2}-\mathrm{s}\right)$ at 20 and $25 \mathrm{~m} / \mathrm{s}$ wind speeds, respectively.

Deflation rates from dry and wet controls (water applied at $2 \mathrm{~L} / \mathrm{m}^{2}$ ) averaged $0.14 \pm 0.10$, 6.4 , and $0.45 \pm 0.28 \mathrm{~g} /\left(\mathrm{m}^{2}-\mathrm{s}\right)$ at $20 \mathrm{~m} / \mathrm{s}$ for the Idaho, Hanford, and McGee Ranch soils, respectively. (Only control cases were tested using the McGee Ranch silt-loam.) The watersprayed wet controls formed crusts of soluble materials on the soil surfaces that provided protection from eolian stresses. Measured deflation rates from Idaho soil wet controls from Batches 1 and 2 were $1.2 \pm 0.95,1.2 \pm 0.54,1.1 \pm 0.86$, and $29 \pm 31 \mathrm{~g} /\left(\mathrm{m}^{2}-\mathrm{s}\right)$ during Subtests 3 , 4,5 , and 6, respectively. Similar results for Hanford soil wet controls were $230 \pm 71 \mathrm{~g} /\left(\mathrm{m}^{2}-\mathrm{s}\right)$ for Subtest 3; the Hanford soil wet controls failed at the end of Subtest 3. Smaller variation in the Idaho soil wet controls was expected and would have aided more clear interpretation of the results.

Application of PS to Idaho soil improved resistance to wind erosion, although the degree of improvement at the least application $\left(1.0 \%\right.$ and $\left.1 \mathrm{~L} / \mathrm{m}^{2}\right)$ was not significant. Surface protection was not a simple function of starch application rate. The best surface protection was favored by high PS concentration (2.5\%) and low water application $\left(1 \mathrm{~L} / \mathrm{m}^{2}\right)$. Even increasung the starch 
content on the surface 4 -fold, the $2.5 \%$ at $4 \mathrm{~L} / \mathrm{m}^{2}$ case, did not perform as well. It is possible that greater water applications washed the starch further into the surface and reduced the integrity of the surface crust. Average surface deflation rates from the best PS-protected surfaces ranged between 0 and $10 \%$ of those from corresponding wet control surfaces.

Tests of XDCA on Idal o soil indicated that the material does not protect that soil from eolian stresses except for undis turbed surfaces treated with a solution concentration of $1: 2$ at an application rate of $9.2 \mathrm{~L} / \mathrm{m}^{2}$. The XDCA crusts generally performed similar to the wet control with the exception of the $1: 2$ at $1.1 \mathrm{~L} / \mathrm{m}^{2}$ case, which provided less protection than the wet control case. Also note the result of XDCA applications on sandy Hanford soil below.

The FPW provided protection of undisturbed Idaho soil surfaces for certain combinations of solution concentration and application quantity. Disturbed surfaces were not significantly protected. Application of FPW at $4 \mathrm{~L} / \mathrm{m}^{2}$ performed better than that of $2 \mathrm{~L} / \mathrm{m}^{2}$ for the single common solution concentration tested $(1: 4)$ and undisturbed surfaces. However, both application quantities performed similarly to the wet controls after the surfaces were disturbed. Applications of $1: 1$ and $1: 2$ solution concentrations resulted in thick, heavily cracked and curled surfaces that were unsteady in their susceptibility to erosion.

The aging process impacted surface crust effectiveness. Tests were performed using Idaho soil. Exposure to uv-cycling did not seem to impact any of the three dust control agents. Moisture-cycling eliminated the effectiveness of PS and FPW crusts but did not seem to significantly impact XDCA crusts.

Soil type, Idaho loamy soil or Hanford sandy soil, had a large impact on the effectiveness of the dust control agents. Idaho soil surfaces were protected by PS other than during Subtests 5 and 6, were not protected by XDCA, and were protected by FPW only during Subtests 3 and 4 . In contrast, Hanford soil surfaces were protected through Subtest 6 by PS and through all subtests by XDCA and FPW. The XDCA clearly provided the best protection of Hanford soil surfaces; deflation rates from the XDCA-protected surfaces never exceeded and were generally much less than $5 \%$ of those from corresponding wet controls. Deflation rates from the FPW-protected Hanford soil surfaces were also small at less than $3,5,13$, and $82 \%$ of the wet control for the disturbed surface case (Subtests $5,6,7$, and 8 , respectively).

The results of this study indicate that all three dust control agents can protect exposed soil surfaces from extreme eolian stresses. It is also clear that the interaction and performance of each agent with various soil types may differ dramatically. Thus, soils similar to that received from INEL should be best protected by high concentration (approximately $2.5 \%$ ) solutions of potato 
starch at low water application levels (approximately 1 to $2 \mathrm{~L} / \mathrm{m}^{2}$ ). Because the effectiveness of PS on this soil type is degraded after a moderate amount of simulated rainfall, other options or additives should be considered if surfaces are to be protected for weeks during periods of intermittent rainfall and hot and windy conditions. In addition, PS applied to wet surfaces might provide reduced surface protection; all tests were performed by spray-coating dry soil surfaces. In contrast to its performance on the Idaho soil, the effectiveness of XDCA on the sandy Hanford soil was near ideal, even during extended wind tunnel testing. The XDCA should be considered when sandy soils are excavated. While fermented potato waste was not the best fixative on either soil, it did perform reasonably well on both soil types (better than XDCA on Idaho soil and better than PS on Hanford soil). Additional development work, perhaps including additives, could produce an improved product.

Although the test surfaces were aged under uv- and moisture-cycling conditions, no attempt was made to determine if insect or microbial activity could degrade (or enhance) the performance of these products. It is recommended that field or laboratory trials include these biological aging parameters. Also regarding possible future tests, the Hanford soil made a better test substrate because it was less cohesive, and replicate tests produced a greater degree of agreement. Because Hanford soil results are based on the results of a small number of tests, it would be prudent to perform additional tests prior to selecting a fugitive dust control agent for use at the Hanford Site. 


\subsection{REFERENCES}

American Society for Testing and Materials (ASTM). 1984. Standard Method for Particle-Size Analysis of Soils. D422-63 (Reapproved 1972), American Society for Testing and Materials, Philadelphia, Pennsylvania.

Glantz, C.S., M.N. Schwartz, K.W. Burk, R.B. Kasper, M.W. Ligotke, and P.J. Perrault. 1990. Climatological Summary of Wind and Temperature Data for the Hanford Meteorology Monitoring Network. PNL-7471, Pacific Northwest Laboratory, Richland, Washington.

Ligotke, M.W., and D.C. Klopfer. 1990. Soil Erosion Rates from Mixed Soil and Gravel Surfaces in a Wind Tunnel. PNL-7435, Pacific Northwest Laboratory, Richland, Washington.

Ligotke, M.W. 1993. Soil Erosion Rates Caused by Wind and Saltating Sand Stresses in a Wind Tunnel. PNL-8478, Pacific Northwest Laboratory, Richland, Washington.

Stone, W.A., J.M. Thorp, O.P Gifford, and D.J. Hoitink. 1983. Climatological Summary for the Hanford Area. PNL-4622, Pacific Northwest Laboratory, Richland, Washington. 


\section{APPENDIX A-A}

\section{WIND EROSION TEST DATA AND DEFLATION RATE RESULTS}

Special Notes: Tests 1 and 2 were trial tests not included in the general data analysis. Tests 1 through 6 were performed using an initial surface elevation $0.3 \mathrm{~cm}$ lower than all subsequent tests. Idaho soil from Batch 1 was used through Test 23, Batch 2 was then used through Test 54, and subsequent tests used Batch 3. 


\begin{tabular}{|c|c|c|c|c|c|c|c|c|c|c|c|}
\hline $\begin{array}{l}\text { Test } \\
\text { No. }\end{array}$ & $\begin{array}{l}\text { Wind } \\
\text { Speed } \\
(\mathrm{m} / \mathrm{s})\end{array}$ & $\begin{array}{c}\Delta t \\
(\min )\end{array}$ & $\begin{array}{c}\Delta M \\
\operatorname{Admix} \\
(\mathrm{g})\end{array}$ & $\begin{array}{c}\text { Total } \\
\text { Deflation } \\
\left(\mathrm{g} / \mathrm{m}^{\wedge} 2-\mathrm{s}\right)\end{array}$ & $\begin{array}{c}\text { Wind } \\
\text { Speed } \\
\text { Calegory } \\
(\mathrm{m} / \mathrm{s})\end{array}$ & $\begin{array}{l}\text { Test } \\
\text { No. }\end{array}$ & $\begin{array}{l}\text { Wind } \\
\text { Speed } \\
(\mathrm{m} / \mathrm{s})\end{array}$ & $\begin{array}{c}\Delta \mathrm{t} \\
(\mathrm{min})\end{array}$ & $\begin{array}{c}\Delta M \\
\text { Admix } \\
\text { (g) }\end{array}$ & $\begin{array}{c}\text { Total } \\
\text { Deflation } \\
\left(\mathrm{s} / \mathrm{m}^{\wedge} 2-\mathrm{s}\right)\end{array}$ & $\begin{array}{l}\text { Wind } \\
\text { Speed } \\
\text { Category } \\
(\mathrm{m} / \mathrm{s})\end{array}$ \\
\hline 1.1 & 9.97 & 15.0 & .3 & $-1.3 \mathrm{E}-02$ & 10.00 & 8.5 & 20.10 & 2.0 & 4 & $1.3 \mathrm{E}-01$ & 20.00 \\
\hline 1.2 & 14.90 & 15.0 & -1 & $-4.4 \mathrm{E}-03$ & 15.00 & $8-6$ & 25.04 & 2.0 & 35 & $1.1 \mathrm{E}+00$ & 25.00 \\
\hline 1.3 & 19.86 & 15.0 & -2 & $-8.7 \mathrm{E}-03$ & 20.00 & 8.7 & 20.13 & 2.0 & .264 & $-8.6 \mathrm{E}+00$ & 20.00 \\
\hline 14 & 24.77 & 15.0 & -1 & $-4.4 E-03$ & 25.00 & 8.8 & 25.04 & 2.0 & .39 & $-1.3 \mathrm{E}+00$ & 25.00 \\
\hline 1.5 & 19.50 & 4.0 & 0 & & 20.00 & & & & & & \\
\hline $1-6$ & 25.05 & 2.0 & 11 & $3.6 \mathrm{E}-01$ & 25.00 & 9.1 & 20.12 & 2.0 & 0 & & 20.00 \\
\hline $1-7$ & 19.71 & 2.0 & 69 & $2.3 \mathrm{E}+00$ & 20.00 & 9.2 & 25.90 & 2.0 & 1 & $3.3 \mathrm{E}-02$ & 25.00 \\
\hline 1.8 & 25.07 & 2.0 & 128 & $4.2 E+\infty 0$ & 25.00 & 9.3 & 19.89 & 2.0 & 5 & $1.6 \mathrm{E}-01$ & 20.00 \\
\hline 1.9 & 19.94 & 1.5 & 775 & $3.4 \mathrm{E}+01$ & 20.00 & 9.4 & 24.82 & 2.0 & 56 & $1.8 \mathrm{E}+00$ & 25.00 \\
\hline \multirow[t]{2}{*}{1.10} & 24.96 & 1.5 & 2606 & $1.1 \mathrm{E}+02$ & 25.00 & 9.5 & 20.33 & 2.0 & 41 & $1.3 \mathrm{E}+00$ & 20.00 \\
\hline & & & & & & 9.6 & 25.06 & 2.0 & 646 & $2.1 E+01$ & 25.00 \\
\hline 2.1 & 15.16 & 15.0 & 1 & $4.4 \mathrm{E}-03$ & 15.00 & 9.7 & 19.97 & 2.0 & -64 & $-2.1 E+00$ & 20.00 \\
\hline 2.2 & 19.91 & 15.0 & 2 & 8.7E-03 & 20.00 & 9.8 & 24.83 & 2.0 & 869 & $2.8 \mathrm{E}+01$ & 25.00 \\
\hline 2.3 & 25.11 & 15.0 & 12 & $5.2 \mathrm{E}-02$ & 25.00 & & & & & & \\
\hline \multirow[t]{2}{*}{$2-4$} & 19.63 & 1.25 & 3973 & $2.1 E+02$ & 20.00 & $10-1$ & 19.88 & 2.0 & 0 & & 20.00 \\
\hline & & & & & & 10.2 & 24.95 & 2.0 & 0 & & 25.00 \\
\hline 3.1 & 19.89 & 15.0 & 0 & & 20.00 & $10-3$ & 19.88 & 2.0 & -22 & $-7.2 \mathrm{E}-01$ & 20.00 \\
\hline 3.2 & 24.96 & 15.0 & 0 & & 25.00 & $10-4$ & 24.99 & 2.0 & -17 & $-5.6 E-01$ & 25.00 \\
\hline $3-3$ & 19.72 & 1.5 & -43 & $-1.9 \mathrm{E}+00$ & 20.00 & 10.5 & 20.13 & 2.0 & 17 & $5.6 \mathrm{E}-01$ & 20.00 \\
\hline 34 & 25.08 & 1.5 & .7 & $-3.1 \mathrm{E}-01$ & 25.00 & $10-6$ & 25.16 & 2.0 & 119 & $3.9 E+00$ & 25.00 \\
\hline 3.5 & 20.10 & 2.0 & 11 & $3.6 \mathrm{E}-01$ & 20.00 & 10.7 & 20.13 & 2.0 & .219 & $-7.2 E+\infty 0$ & 20.00 \\
\hline $3-6$ & 25.09 & 2.0 & 107 & $3.5 E+\infty$ & 25.00 & $10-8$ & 25.07 & 2.0 & -67 & $-2.2 \mathrm{E}+\infty 0$ & 25.00 \\
\hline 3.7 & 20.09 & 2.0 & .185 & $-6.0 \mathrm{E}+\infty 0$ & 20.00 & & & & & & \\
\hline \multirow[t]{2}{*}{3.8} & 24.98 & 2.0 & 666 & $2.2 \mathrm{E}+01$ & 25.00 & $11 \cdot 1$ & 9.87 & 5.0 & 16 & $2.1 E-01$ & 10.00 \\
\hline & & & & & & 11.2 & 14.99 & 5.0 & 99 & $1.3 E+00$ & 15.00 \\
\hline $4-1$ & 19.99 & 2.0 & 1 & $3.3 \mathrm{E}-02$ & 20.00 & $11-3$ & 19.77 & 2.0 & 274 & $9.0 \mathrm{E}+00$ & 20.00 \\
\hline 4.2 & 25.00 & 2.0 & 0 & & 25.00 & $11-4$ & 24.74 & 2.0 & 566 & $1.8 \mathrm{E}+01$ & 25.00 \\
\hline $4-3$ & 20.03 & 2.0 & -22 & $-7.2 \mathrm{E}-01$ & 20.00 & 11.5 & 19.98 & 2.0 & 279 & $9.1 E+00$ & 20.00 \\
\hline $4-4$ & 25.04 & 2.0 & .13 & $-4.2 \mathrm{E}-01$ & 25.00 & 11.6 & 24.83 & 2.0 & 825 & $2.7 E+01$ & 25.00 \\
\hline 4.5 & 20.26 & 2.0 & 12 & $3.9 \mathrm{E}-01$ & 20.00 & & & & & & \\
\hline $4-6$ & 25.28 & 2.0 & 102 & $3.3 E+\infty 0$ & 25.00 & $12-1$ & 19.95 & 2.0 & 1 & $3.3 \mathrm{E}-02$ & 20.00 \\
\hline 4.7 & 20.10 & 2.0 & .288 & $-9.4 \mathrm{E}+00$ & 20.00 & 12.2 & 25.12 & 2.0 & 1 & 3.3E-02 & 25.00 \\
\hline \multirow[t]{2}{*}{4.8} & 25.24 & 2.0 & .67 & $-2.2 E+00$ & 25.00 & 12.3 & 19.99 & 2.0 & 30 & $9.8 \mathrm{E}-01$ & 20.00 \\
\hline & & & & & & $12-4$ & 24.88 & 2.0 & 53 & $1.7 E+00$ & 25.00 \\
\hline 5.1 & 9.75 & 5.0 & 0 & & 10.00 & 12.5 & 19.98 & 2.0 & 70 & $2.3 \mathrm{E}+00$ & 20.00 \\
\hline $5-2$ & 14.91 & 5.0 & 54 & $7.1 \mathrm{E}-01$ & 15.00 & $12-6$ & 24.78 & 2.0 & 2155 & $7.0 \mathrm{E}+01$ & 25.00 \\
\hline 5.3 & 20.05 & 2.0 & 450 & $1.5 E+01$ & 20.00 & & & & & & \\
\hline $5-4$ & 24.88 & 2.0 & 402 & $1.3 \mathrm{E}+01$ & 25.00 & $13-1$ & 20.01 & 2.0 & 0 & & 20.00 \\
\hline 5.5 & 19.82 & 2.0 & 345 & $1.1 \mathrm{E}+01$ & 20.00 & 13.2 & 25.12 & 2.0 & 0 & & 25.00 \\
\hline \multirow[t]{2}{*}{5.6} & 19.91 & 2.0 & 10 & $3.3 \mathrm{E}-01$ & 20.00 & 13.3 & 20.05 & 2.0 & -7 & $-2.3 \mathrm{E}-01$ & 20.00 \\
\hline & & & & & & $13-4$ & 25.02 & 2.0 & -5 & $-1.6 \mathrm{E}-01$ & 25.00 \\
\hline 6.1 & 20.14 & 2.0 & 0 & & 20.00 & 13.5 & 20.13 & 2.0 & 24 & $7.8 \mathrm{E}-01$ & 20.00 \\
\hline $6-2$ & 25.02 & 2.0 & 0 & & 25.00 & $13-6$ & 25.11 & 2.0 & 167 & $5.5 E+\infty 0$ & 25.00 \\
\hline 6.3 & 19.94 & 2.0 & 0 & & 20.00 & 13.7 & 20.03 & 2.0 & .174 & $-5.7 E+\infty 0$ & 20.00 \\
\hline $6-4$ & 24.99 & 2.0 & 45 & $1.5 E+\infty 0$ & 25.00 & $13-8$ & 24.89 & 2.0 & 296 & $9.7 \mathrm{E}+00$ & 25.00 \\
\hline 6.5 & 20.08 & 2.0 & 24 & $7.8 \mathrm{E}-01$ & 20.00 & & & & & & \\
\hline $6-6$ & 24.94 & 2.0 & 169 & $5.5 E+00$ & 25.00 & $14-1$ & 19.81 & 2.0 & 0 & & 20.00 \\
\hline 6.7 & 20. & 2.0 & .22 & $-7.2 \mathrm{E}-01$ & & $14-2$ & 24.82 & 2.0 & 0 & & 25.00 \\
\hline \multirow[t]{2}{*}{6.8} & 25. & 2.0 & 969 & $3.2 \mathrm{E}+01$ & & 14.3 & 19.89 & 2.0 & -8 & $-2.6 \mathrm{E}-01$ & 20.00 \\
\hline & & & & & & $14-4$ & 24.83 & 2.0 & -4 & $-1.3 \mathrm{E}-01$ & 25.00 \\
\hline $7 \cdot 1$ & 20.31 & 2.0 & -1 & $-3.3 \mathrm{E}-02$ & 20.00 & $14-5$ & 20.30 & 2.0 & 13 & $4.2 \mathrm{E}-01$ & 20.00 \\
\hline 7.2 & 25.30 & 2.0 & .1 & $-3.3 \mathrm{E}-02$ & 25.00 & $14-6$ & 25.11 & 2.0 & 104 & $3.4 \mathrm{E}+00$ & 25.00 \\
\hline 7.3 & 20.05 & 2.0 & .17 & $-5.6 \mathrm{E}-01$ & 20.00 & $14-7$ & 19.85 & 2.0 & .178 & $-5.8 \mathrm{E}+00$ & 20.00 \\
\hline 74 & 25.16 & 2.0 & .5 & $-1.6 \mathrm{E}-01$ & 25.00 & $14-8$ & 24.86 & 2.0 & 181 & $5.9 E+\infty 0$ & 25.00 \\
\hline 7.5 & 20.21 & 2.0 & 34 & $1.1 \mathrm{E}+00$ & 20.00 & & & & & & \\
\hline 7.6 & 25.06 & 2.0 & 146 & $4.8 \mathrm{E}+00$ & 25.00 & 15.1 & 19.76 & 2.0 & 1 & $3.3 \mathrm{E}-02$ & 20.00 \\
\hline 7.7 & 20.00 & 2.0 & .169 & $-5.5 E+00$ & 20.00 & 15.2 & 24.74 & 2.0 & 0 & & 25.00 \\
\hline \multirow[t]{2}{*}{7.8} & 24.91 & 2.0 & 141 & $4.6 \mathrm{E}+\infty 0$ & 25.00 & 15.3 & 19.71 & 2.0 & -10 & $-3.3 \mathrm{E}-0 \mathrm{I}$ & 20.00 \\
\hline & & & & & & $15-4$ & 24.88 & 2.0 & -4 & $-1.3 \mathrm{E}-01$ & 25.00 \\
\hline 8.1 & 19.81 & 2.0 & 0 & & 20.00 & 15.5 & 20.10 & 2.0 & 4 & 1.3E-01 & 20.00 \\
\hline $8-2$ & 24.83 & 2.0 & .1 & $-3.3 \mathrm{E}-02$ & 25.00 & 15.6 & 25.05 & 2.0 & 67 & $2.2 \mathrm{E}+00$ & 25.00 \\
\hline $8-3$ & 19.86 & 2.0 & .23 & $-7.5 \mathrm{E}-01$ & 20.00 & 15.7 & 19.90 & 2.0 & -272 & $-8.9 \mathrm{E}+00$ & 20.00 \\
\hline $8-4$ & 24.89 & 2.0 & .5 & $-1.6 \mathrm{E}-01$ & 25.00 & 15.8 & 24.91 & 2.0 & -2 & $-6.5 \mathrm{E}-02$ & 25.00 \\
\hline
\end{tabular}

Mass gains from exposure to saltating sand reported as negative (-) mass losses. 


\begin{tabular}{|c|c|c|c|c|c|c|c|c|c|c|c|}
\hline $\begin{array}{l}\text { Test } \\
\text { No. }\end{array}$ & $\begin{array}{l}\text { Wind } \\
\text { Speed } \\
(\mathrm{m} / \mathrm{s})\end{array}$ & $\begin{array}{c}\Delta t \\
(\mathrm{~min})\end{array}$ & $\begin{array}{c}\Delta \mathrm{M} \\
\text { Admix* } \\
(\mathrm{g}) \\
\end{array}$ & $\begin{array}{c}\text { Total } \\
\text { Deflation } \\
\left(\mathrm{g} / \mathrm{m}^{\wedge} 2-\mathrm{s}\right)\end{array}$ & $\begin{array}{c}\text { Wind } \\
\text { Speed } \\
\text { Category } \\
(\mathrm{m} / \mathrm{s})\end{array}$ & $\begin{array}{l}\text { Test } \\
\text { No. }\end{array}$ & $\begin{array}{l}\text { Wind } \\
\text { Speed } \\
(\mathrm{m} / \mathrm{s})\end{array}$ & $\begin{array}{c}\Delta t \\
(\mathrm{~min})\end{array}$ & $\begin{array}{c}\Delta \mathrm{M} \\
\operatorname{Admix} \\
\text { (g) }\end{array}$ & $\begin{array}{c}\text { Total } \\
\text { Deflation } \\
\left(\mathrm{g} / \mathrm{m}^{\wedge} 2 \cdot \mathrm{s}\right)\end{array}$ & $\begin{array}{l}\text { Wind } \\
\text { Speed } \\
\text { Category } \\
(\mathrm{m} / \mathrm{s})\end{array}$ \\
\hline $16-1$ & 19.79 & 2.0 & 0 & & 20.00 & 23.3 & 19.82 & 2.0 & .11 & $-3.6 \mathrm{E}-01$ & 20.00 \\
\hline $16-2$ & 24.76 & 2.0 & 0 & & 25.00 & $23-4$ & 25.11 & 2.0 & 2 & $6.5 \mathrm{E}-02$ & 25.00 \\
\hline 16.3 & 19.80 & 2.0 & .5 & $-1.6 \mathrm{E}-01$ & 20.00 & 23.5 & 20.03 & 2.0 & 7 & $2.3 E-01$ & 20.00 \\
\hline $16-4$ & 24.87 & 2.0 & -1 & $-3.3 \mathrm{E}-02$ & 25.00 & $23-6$ & 24.14 & 2.0 & 63 & $2.1 E+00$ & 25.00 \\
\hline 16.5 & 19.80 & 2.0 & 4 & $1.3 \mathrm{E}-01$ & 20.00 & $23-7$ & 19.90 & 2.0 & -170 & $-5.6 \mathrm{E}+00$ & 20.00 \\
\hline $16-6$ & 24.99 & 2.0 & 40 & $1.3 \mathrm{E}+00$ & 25.00 & 23.8 & 24.99 & 2.0 & 187 & $6.1 E+\infty 0$ & 25.00 \\
\hline $16-7$ & 19.92 & 2.0 & .263 & $-8.6 \mathrm{E}+00$ & 20.00 & & & & & & \\
\hline \multirow[t]{2}{*}{$16-8$} & 24.95 & 2.0 & $\$ 2$ & $3.0 \mathrm{E}+\infty 0$ & 25.00 & 24.1 & 19.83 & 2.0 & 0 & & 20.00 \\
\hline & & & & & & $24-2$ & 24.81 & 2.0 & 0 & & 25.00 \\
\hline 17.1 & 20.57 & 2.0 & 0 & & 20.00 & $24-3$ & 19.82 & 2.0 & 39 & $1.3 \mathrm{E}+00$ & 20.00 \\
\hline 17.2 & 25.37 & 2.0 & 0 & & 25.00 & $24-4$ & 24.82 & 2.0 & 36 & $1.2 \mathrm{E}+00$ & 25.00 \\
\hline 17.3 & 20.28 & 2.0 & .12 & $-3.9 \mathrm{E}-01$ & 20.00 & $24-5$ & 19.94 & 2.0 & 133 & $4.3 \mathrm{E}+00$ & 20.00 \\
\hline $17-4$ & 25.16 & 2.0 & -4 & $-1,3 \mathrm{E}-01$ & 25.00 & $24-6 a$ & 24.95 & 1.0 & 1491 & $9.7 \mathrm{E}+01$ & 25.00 \\
\hline 17.5 & 20.34 & 2.0 & 3 & $9.8 \mathrm{E}-02$ & 20.00 & $24-6 b$ & 24.85 & 1.0 & 175 & $1.1 E+01$ & 25.00 \\
\hline $17-6$ & 25.12 & 2.0 & 45 & $1.5 \mathrm{E}+\infty$ & 25.00 & & & & & & \\
\hline 17.7 & 20.01 & 2.0 & .295 & $-9.6 \mathrm{E}+\infty 0$ & 20.00 & $25-1$ & 20.00 & 2.0 & 3 & $9.8 \mathrm{E}-02$ & 20.00 \\
\hline \multirow[t]{2}{*}{17.8} & 24.93 & 2.0 & 62 & $2.0 \mathrm{E}+00$ & 25.00 & 25.2 & 24.93 & 2.0 & 14 & $4.6 \mathrm{E}-01$ & 25.00 \\
\hline & & & & & & 25.3 & 19.92 & 2.0 & 711 & $2.3 \mathrm{E}+01$ & 20.00 \\
\hline 18.1 & 20.02 & 2.0 & 0 & & 20.00 & $25-4$ & 24.89 & 2.0 & 1222 & $4.0 \mathrm{E}+01$ & 25.00 \\
\hline $18-2$ & 24.77 & 2.0 & 0 & & 25.00 & & & & & & \\
\hline 18.3 & 19.90 & 2.0 & .22 & $-7.2 \mathrm{E}-01$ & 20.00 & 26.1 & 9.95 & 5.0 & 10 & $1.3 \mathrm{E}-01$ & 10.00 \\
\hline $18-4$ & 24.98 & 2.0 & .15 & $-4.9 \mathrm{E}-01$ & 25.00 & $26-2$ & 14.97 & 5.0 & 86 & $1.1 \mathrm{E}+00$ & 15.00 \\
\hline 18.5 & 20.27 & 2.0 & 5 & $1.6 \mathrm{E}-01$ & 20.00 & $26-3$ & 20.17 & 2.0 & 298 & $9.7 \mathrm{E}+00$ & 20.00 \\
\hline $18-6$ & 25.22 & 2.0 & 31 & $1.0 \mathrm{E}+\infty 0$ & 25.00 & $26-4$ & 25.08 & 2.0 & 1407 & $4.6 \mathrm{E}+01$ & 25.00 \\
\hline 18.7 & 20.16 & 2.0 & .252 & $-8.2 \mathrm{E}+\infty$ & 20.00 & & & & & & \\
\hline \multirow[t]{2}{*}{$18-8$} & 25.12 & 2.0 & -71 & $-2.3 E+00$ & 25.00 & 27.1 & 20.00 & 2.0 & 0 & & 20.00 \\
\hline & & & & & & 27.2 & 24.92 & 2.0 & 0 & & 25.00 \\
\hline 19.1 & 19.93 & 2.0 & 0 & & 20.00 & 27.3 & 19.92 & 2.0 & 61 & $2.0 \mathrm{E}+00$ & 20.00 \\
\hline 19.2 & 25.02 & 2.0 & 0 & & 25.00 & $27-4$ & 24.90 & 2.0 & 48 & $1.6 \mathrm{E}+00$ & 25.00 \\
\hline 19.3 & 20.09 & 2.0 & -4 & $-1.3 \mathrm{E}-01$ & 20.00 & 27.5 & 20.11 & 2.0 & 18 & $5.9 \mathrm{E}-01$ & 20.00 \\
\hline $19-4$ & 25.04 & 2.0 & .3 & $-9.8 \mathrm{E}-02$ & 25.00 & $27-6$ & 24.95 & 2.0 & 265 & $8.7 E+00$ & 25.00 \\
\hline 19.5 & 20.13 & 2.0 & 31 & $1.0 \mathrm{E}+\infty$ & 20.00 & 27.7 & 19.95 & 2.0 & -15 & $-4.9 \mathrm{E}-01$ & 20.00 \\
\hline $19-6$ & 24.97 & 2.0 & 888 & $2.9 \mathrm{E}+01$ & 25.00 & $27-8$ & 24.84 & 2.0 & 914 & $3.0 \mathrm{E}+01$ & 25.00 \\
\hline 19.7 & 19.97 & 2.0 & 14 & $4.6 \mathrm{E}-01$ & 20.00 & & & & & & \\
\hline \multirow[t]{2}{*}{19.8} & 24.74 & 2.0 & 1279 & $4.2 E+01$ & 25.00 & $28-1$ & 19.91 & 2.0 & .1 & $-3.3 \mathrm{E}-02$ & 20.00 \\
\hline & & & & & & 28.2 & 24.86 & 2.0 & 0 & & 25.00 \\
\hline 20.1 & 19.88 & 2.0 & 1 & $3.3 \mathrm{E}-02$ & 20.00 & $28-3$ & 19.90 & 2.0 & -4 & $-1,3 \mathrm{E}-01$ & 20.00 \\
\hline 20.2 & 24.91 & 2.0 & 1 & $3.3 \mathrm{E}-02$ & 25.00 & $28-4$ & 24.79 & 2.0 & -3 & $-9.8 \mathrm{E}-02$ & 25.00 \\
\hline $20-3$ & 19.97 & 2.0 & -3 & $-9.8 \mathrm{E}-02$ & 20.00 & $28-5$ & 20.14 & 2.0 & 11 & $3.6 \mathrm{E}-01$ & 20.00 \\
\hline $20-4$ & 24.90 & 2.0 & 1 & $3.3 \mathrm{E}-02$ & 25.00 & $28-6$ & 25.08 & 2.0 & 114 & $3.7 E+00$ & 25.00 \\
\hline $20-5$ & 20.04 & 2.0 & 26 & 8.5E-01 & 20.00 & 28.7 & 19.83 & 2.0 & .176 & $-5.8 E+\infty 0$ & 20.00 \\
\hline $20-6$ & 25.20 & 2.0 & 992 & $3.2 E+01$ & 25.00 & 28.8 & 24.87 & 2.0 & 200 & $6.5 E+00$ & 25.00 \\
\hline $20-7$ & 19.98 & 2.0 & 4 & $1.3 \mathrm{E}-01$ & 20.00 & & & & & & \\
\hline \multirow[t]{2}{*}{$20-8$} & 24.87 & 2.0 & 998 & $3.3 E+01$ & 25.00 & $29-5$ & 20.14 & 2.0 & 3 & $9.8 \mathrm{E}-02$ & 20.00 \\
\hline & & & & & & $29-6$ & 24.84 & 2.0 & 76 & $2.5 E+00$ & 25.00 \\
\hline $21-1$ & 9.85 & 5.0 & 0 & & 10.00 & 29.7 & 19.97 & 2.0 & -192 & $-6.3 E+\infty 0$ & 20.00 \\
\hline $21-2$ & 14.96 & 5.0 & 26 & $3.4 \mathrm{E}-01$ & 15.00 & $29-8$ & 25.01 & 2.0 & 167 & $5.5 E+00$ & 25.00 \\
\hline $21 \cdot 3$ & 19.81 & 2.0 & 123 & $4.0 \mathrm{E}+00$ & 20.00 & & & & & & \\
\hline $21-4$ & 24.71 & 2.0 & 586 & $1.9 \mathrm{E}+01$ & 25.00 & $30-1$ & 20.29 & 2.0 & 0 & & 20.00 \\
\hline $21-5$ & 19.75 & 2.0 & 35 & $1.1 E+\infty 0$ & 20.00 & $30-2$ & 25.05 & 2.0 & 1 & $3.3 \mathrm{E}-02$ & 25.00 \\
\hline \multirow[t]{2}{*}{$21-6$} & 24.77 & 2.0 & 539 & $1.8 \mathrm{E}+01$ & 25.00 & 30.3 & 20.14 & 2.0 & 23 & $7.5 \mathrm{E}-01$ & 20.00 \\
\hline & & & & & & $30-4$ & 25.03 & 2.0 & 16 & $5.2 \mathrm{E}-01$ & 25.00 \\
\hline $22-1$ & 19.97 & 2.0 & 0 & & 20.00 & $30-5$ & 20.05 & 2.0 & 70 & $2.3 E+00$ & 20.00 \\
\hline 22.2 & 25.03 & 2.0 & 0 & & 25.00 & 30.6 & 25.00 & 2.0 & 1784 & $5.8 \mathrm{E}+01$ & 25.00 \\
\hline 22.3 & 19.98 & 2.0 & 20 & $6.5 \mathrm{E}-01$ & 20.00 & & & & & & \\
\hline $22-4$ & 24.80 & 2.0 & 24 & $7.8 \mathrm{E}-01$ & 25.00 & $31-1$ & 19.91 & 2.0 & 0 & & 20.00 \\
\hline 22.5 & 20.11 & 2.0 & 6 & 2.0E-01 & 20.00 & $31-2$ & 25.01 & 2.0 & 0 & & 25.00 \\
\hline $22-6$ & 25.16 & 2.0 & 177 & $5.8 E+\infty 0$ & 25.00 & $31-3$ & 19.90 & 2.0 & 7 & $2.3 \mathrm{E}-01$ & 20.00 \\
\hline $22-7$ & 19.92 & 2.0 & .123 & $-4.0 \mathrm{E}+00$ & 20.00 & $31-4$ & 24.84 & 2.0 & 4 & $1.3 \mathrm{E}-01$ & 25.00 \\
\hline \multirow[t]{2}{*}{$22-8$} & 24.87 & 2.0 & 429 & $1.4 E+01$ & 25.00 & 31.5 & 20.02 & 2.0 & 52 & $1.7 \mathrm{E}+00$ & 20.00 \\
\hline & & & & & & $31-6$ & 24.87 & 2.0 & 966 & $3.2 E+01$ & 25.00 \\
\hline $23-1$ & 19.98 & 2.0 & 1 & 3.3E-02 & 20.00 & $31-7$ & 20.37 & 2.0 & -12 & $-3.9 \mathrm{E}-01$ & 20.00 \\
\hline $23-2$ & 25.03 & 2.0 & 0 & & 25.00 & 31.8 & 24.83 & 2.0 & 450 & $1.5 E+01$ & 25.00 \\
\hline
\end{tabular}

- Mass gains from exposure to saltating sand reported as negadive (-) mass losses. 


\begin{tabular}{|c|c|c|c|c|c|c|c|c|c|c|c|}
\hline $\begin{array}{l}\text { Test } \\
\text { No. }\end{array}$ & $\begin{array}{l}\text { Wind } \\
\text { Speed } \\
(\mathrm{m} / \mathrm{s})\end{array}$ & $\begin{array}{c}\Delta t \\
(\min )\end{array}$ & $\begin{array}{c}\Delta M \\
\text { Admix } \\
(\mathrm{R}) \\
\end{array}$ & $\begin{array}{c}\text { Total } \\
\text { Deflation } \\
\left(\mathrm{g} / \mathrm{m}^{\wedge} 2-\mathrm{s}\right)\end{array}$ & $\begin{array}{c}\text { Wind } \\
\text { Speed } \\
\text { Category } \\
(\mathrm{m} / \mathrm{s})\end{array}$ & $\begin{array}{l}\text { Test } \\
\text { No. } \\
\end{array}$ & $\begin{array}{l}\text { Wind } \\
\text { Speed } \\
(\mathrm{m} / \mathrm{s}) \\
\end{array}$ & $\begin{array}{c}\Delta t \\
(\mathrm{~m} i \mathrm{n})\end{array}$ & $\begin{array}{c}\Delta M \\
\text { Admix } \\
(\mathrm{R}) \\
\end{array}$ & $\begin{array}{c}\text { Total } \\
\text { Deflation } \\
\left(\mathrm{g} / \mathrm{m}^{\wedge} 2-\mathrm{s}\right)\end{array}$ & $\begin{array}{l}\text { Wind } \\
\text { Speed } \\
\text { Category } \\
(\mathrm{m} / \mathrm{s})\end{array}$ \\
\hline 32.1 & 20.03 & 2.0 & 1 & $3.3 \mathrm{E}-02$ & 20.00 & 40.6 & 25.16 & 2.0 & 784 & $2.6 \mathrm{E}+01$ & 25.00 \\
\hline $32-2$ & 24.89 & 2.0 & 6 & 2.0E-01 & 25.00 & 40.8 & 25.13 & $: n$ & 199 & $6.5 E+00$ & 25.00 \\
\hline 32.3 & 20.10 & 2.0 & 686 & $2.2 \mathrm{E}+01$ & 20.00 & 40.9 & 25.01 & 2.0 & 182 & $5.9 \mathrm{E}+00$ & 23.00 \\
\hline \multirow[t]{2}{*}{$32-4$} & 25.13 & 2.0 & 1139 & $3.7 E+01$ & 25.00 & & & & & & \\
\hline & & & & & & 41.1 & 19.89 & 2.0 & 0 & & 20.00 \\
\hline $33-1$ & 19.99 & 2.0 & 0 & & 20.00 & 41.2 & 24.84 & 2.0 & 2 & $6.5 \mathrm{E}-02$ & 25.00 \\
\hline 33.2 & 25.04 & 2.0 & 2 & $6.5 E-02$ & 25.00 & $41 \cdot 3$ & 19.76 & 2.0 & .1 & $-3.3 \mathrm{E}-02$ & 20.00 \\
\hline 33.3 & 20.04 & 2.0 & 51 & $1.7 E+\infty$ & 20.00 & $41-4$ & 24.90 & 2.0 & 2 & $6.5 \mathrm{E}-02$ & 25.00 \\
\hline $33-4$ & 24.89 & 2.0 & 67 & $2.2 \mathrm{E}+00$ & 25.00 & 41.5 & 20.18 & 2.0 & 33 & $1,1 E+00$ & 20.00 \\
\hline $33-5$ & 20.05 & 2.0 & 95 & $3.1 E+\infty$ & 20.00 & 41.6 & 24.82 & 2.0 & 927 & $3.0 \mathrm{E}+01$ & 25.00 \\
\hline $33-6$ & 24.77 & 2.0 & 1556 & $5.1 E+01$ & 25.00 & 41.7 & 20.01 & 2.0 & 4 & $-1.3 \mathrm{E}-01$ & 20.00 \\
\hline 33.7 & 19.77 & 2.0 & .7 & $-2.3 \mathrm{E}-01$ & 20.00 & 41.8 & 25.03 & 2.0 & 287 & $9.4 \mathrm{E}+00$ & 25.00 \\
\hline \multirow[t]{2}{*}{$33-8$} & 25.00 & 2.0 & 635 & $2.1 E+01$ & 25.00 & & & & & & \\
\hline & & & & & & 42.1 & 19.99 & 2.0 & -2 & $-6.5 \mathrm{E}-02$ & 20.00 \\
\hline 34.1 & 19.87 & 2.0 & 0 & & 20.00 & 42.2 & 25.12 & 2.0 & 0 & & 25.00 \\
\hline 34.2 & 24.94 & 2.0 & 3 & $9.8 \mathrm{E}-02$ & 25.00 & $42-3$ & 20.07 & 2.0 & 13 & $4.2 \mathrm{E}-01$ & 20.00 \\
\hline 34.3 & 19.92 & 2.0 & 157 & $5.1 E+\infty 0$ & 20.00 & $42-4$ & 25.15 & 2.0 & 30 & $9.8 \mathrm{E}-01$ & 25.00 \\
\hline $34-4$ & 25.02 & 2.0 & 288 & $9.4 E+\infty 0$ & 25.00 & 42.5 & 20.08 & 2.0 & 24 & $7.8 \mathrm{E}-01$ & 20.00 \\
\hline $34-5$ & 19.87 & 2.0 & 48 & $1.6 E+\infty 0$ & 20.00 & 42.6 & 24.80 & 2.0 & 1084 & $3.5 E+01$ & 25.00 \\
\hline \multirow[t]{2}{*}{$34-6$} & 24.89 & 2.0 & 1119 & $3.7 E+01$ & 25.00 & 42.7 & 19.83 & 2.0 & .34 & $-1.1 \mathrm{E}+00$ & 20.00 \\
\hline & & & & & & 42.8 & 24.72 & 2.0 & 742 & $2.4 \mathrm{E}+01$ & 25.00 \\
\hline 35.1 & 19.98 & 2.0 & 0 & & 20.00 & & & & & & \\
\hline 35.2 & 24.98 & 2.0 & 2 & 6.5E-02 & 25.00 & 43.1 & 20.06 & 2.0 & .2 & $-6.5 \mathrm{E}-02$ & 20.00 \\
\hline $35-3$ & 19.93 & 2.0 & 101 & $3.3 E+\infty 0$ & 20.00 & 43.2 & 25.01 & 2.0 & 0 & & 25.00 \\
\hline $35-4$ & 25.11 & 2.0 & 178 & $5.8 E+\infty 0$ & 25.00 & 43.3 & 19.95 & 2.0 & 4 & $-1.3 \mathrm{E}-01$ & 20.00 \\
\hline 35.5 & 19.95 & 2.0 & 29 & $9.5 \mathrm{E}-01$ & 20.00 & $43-4$ & 25.02 & 2.0 & 5 & $1.6 \mathrm{E}-01$ & 25.00 \\
\hline \multirow[t]{2}{*}{$35-6$} & 24.98 & 2.0 & 1265 & 4.1E+01 & 25.00 & 43.5 & 20.03 & 2.0 & 41 & $1.3 E+\infty 0$ & 20.00 \\
\hline & & & & & & 43.6 & 24.87 & 2.0 & 1290 & $4.2 \mathrm{E}+01$ & 25.00 \\
\hline 36.1 & 9.96 & 5.0 & 21 & $2.7 \mathrm{E}-01$ & 10.00 & & & & & & \\
\hline $36-2$ & 14.90 & 5.0 & 141 & $1.8 E+\infty 0$ & 15.00 & $44-1$ & 20.20 & 2.0 & 1 & $3.3 E-02$ & 20.00 \\
\hline 36.3 & 19.88 & 2.0 & 568 & $1.9 E+01$ & 20.00 & $44-2$ & 25.02 & 2.0 & 4 & $1.3 \mathrm{E}-01$ & 25.00 \\
\hline \multirow[t]{2}{*}{$36-4$} & 24.64 & 2.0 & 3358 & $1.1 \mathrm{E}+02$ & 25.00 & $44-3$ & 19.98 & 2.0 & 50 & $1.6 \mathrm{E}+00$ & 20.00 \\
\hline & & & & & & $44-4$ & 25.05 & 2.0 & 150 & $4.9 \mathrm{E}+00$ & 25.00 \\
\hline 37.1 & 19.90 & 2.0 & .1 & $-3.3 \mathrm{E}-02$ & 20.00 & 44.5 & 19.97 & 2.0 & 125 & 4. $1 \mathrm{E}+00$ & 20.00 \\
\hline 37.2 & 25.03 & 2.0 & 1 & $3.3 E-02$ & 25.00 & 44.6 & 24.85 & 2.0 & 1425 & $4.7 E+01$ & 25.00 \\
\hline 37.3 & 19.99 & 2.0 & 71 & $2.3 E+\infty 0$ & 20.00 & & & & & & \\
\hline 374 & 25.16 & 2.0 & 99 & $3.2 E+00$ & 25.00 & 45.1 & 19.89 & 2.0 & 0 & & 20.00 \\
\hline 37.5 & 19.92 & 2.0 & 31 & $1.7 \mathrm{E}+00$ & 20.00 & 45.2 & 24.98 & 2.0 & 1 & $3.3 E-02$ & 25.00 \\
\hline \multirow[t]{2}{*}{$37-6$} & 24.92 & 2.0 & 1719 & $5.6 \mathrm{E}+01$ & 25.00 & 45.3 & 19.97 & 2.0 & 33 & $1.1 E+\infty 0$ & 20.00 \\
\hline & & & & & & $45-4$ & 25.03 & 2.0 & 61 & $2.0 \mathrm{E}+\infty 0$ & 25.00 \\
\hline 38.1 & 19.94 & 2.0 & 0 & & 20.00 & 45.5 & 20.04 & 2.0 & 102 & $3.3 \mathrm{E}+00$ & 20.00 \\
\hline 38.2 & 24.94 & 2.0 & -1 & $-3.3 E-02$ & 25.00 & $45-6$ & 24.90 & 2.0 & 1617 & $5.3 E+01$ & 25.00 \\
\hline $38-3$ & 19.94 & 2.0 & -2 & $-6.5 E-02$ & 20.00 & & & & & & \\
\hline $38-4$ & 24.79 & 2.0 & .3 & $-9.8 \mathrm{E}-02$ & 25.00 & $46-1$ & 20.38 & 2.0 & 41 & $1.3 \mathrm{E}+00$ & 20.00 \\
\hline $38-5$ & 20.15 & 2.0 & 29 & 9.5E-01 & 20.00 & $46-2$ & 25.07 & 2.0 & 49 & $1.6 E+00$ & 25.00 \\
\hline $38-6$ & 24.88 & 2.0 & 203 & $6.6 \mathrm{E}+\infty 0$ & 25.00 & $46-3$ & 19.93 & 2.0 & 6938 & $2.3 E+02$ & 20.00 \\
\hline 38.7 & 19.93 & 2.0 & .75 & $-2.5 E+00$ & 20.00 & & & & & & \\
\hline \multirow[t]{2}{*}{$38-8$} & 24.94 & 2.0 & 181 & $5.9 E+\infty 0$ & 25.00 & 47.1 & 20.25 & 2.0 & 30 & $1.6 \mathrm{E}+00$ & 20.00 \\
\hline & & & & & & 47.2 & 24.95 & 2.0 & 78 & $2.5 E+00$ & 25.00 \\
\hline 39.1 & 19.68 & 2.0 & 0 & & 20.00 & $47-3 a$ & 19.89 & 1.0 & 4436 & $2.9 E+02$ & 20.00 \\
\hline 39.2 & 24.76 & 2.0 & 0 & & 25.00 & 47.36 & 19.90 & 1.0 & 2227 & $1.5 \mathrm{E}+02$ & 20.00 \\
\hline 39.3 & 19.81 & 2.0 & $\cdot 3$ & $-9.8 E-02$ & 20.00 & & & & & & \\
\hline 39.4 & 24.92 & 2.0 & .3 & $-9.8 \mathrm{E}-02$ & 25.00 & $48-1$ & 20.24 & 2.0 & .2 & $-6.5 E-02$ & 20.00 \\
\hline 39.5 & 20.16 & 2.0 & 19 & $6.2 \mathrm{E}-01$ & 20.00 & $48-2$ & 24.82 & 2.0 & 0 & & 25.00 \\
\hline $39-6$ & 25.13 & 2.0 & 207 & $6.8 E+\infty 0$ & 25.00 & $48 \cdot 3$ & 20.16 & 2.0 & -6 & $-2.0 \mathrm{E}-01$ & 20.00 \\
\hline 39.7 & 20.06 & 2.0 & .109 & $-3.6 E+\infty 0$ & 20.00 & $48-4$ & 25.06 & 2.0 & 2 & $6.5 E-02$ & 2.5 .00 \\
\hline \multirow[t]{2}{*}{39.8} & 25.00 & 2.0 & 195 & $6.4 \hat{E}+\infty 0$ & 25.00 & 48.5 & 20.15 & 2.0 & 48 & $1.6 \mathrm{E}+00$ & 20.00 \\
\hline & & & & & & 48.6 & 25.12 & 2.0 & 841 & $2.7 E+01$ & 25.00 \\
\hline 40.1 & 20.09 & 2.0 & 2 & $6.5 E-02$ & 20.00 & 48.7 & 19.96 & 2.0 & .71 & $-2.3 \mathrm{E}+\infty$ & 20.00 \\
\hline $40-2$ & 24.68 & 2.0 & 0 & & 25.00 & 48.8 & 24.95 & 2.0 & 1260 & $4.1 E+01$ & 25.00 \\
\hline 40.3 & 20.09 & 2.0 & 9 & $2.9 \mathrm{E}-01$ & 20.00 & & & & & & \\
\hline $40-4$ & 25.12 & 2.0 & .1 & $-3.3 \mathrm{E}-02$ & 25.00 & & & & & & \\
\hline 40.5 & 20.19 & 2.0 & 54 & $1.8 \mathrm{E}+00$ & 20.00 & & & & & & \\
\hline
\end{tabular}




\begin{tabular}{|c|c|c|c|c|c|c|c|c|c|c|c|}
\hline $\begin{array}{l}\text { Test } \\
\text { No. }\end{array}$ & $\begin{array}{l}\text { Wind } \\
\text { Speed } \\
(\mathrm{m} / \mathrm{s})\end{array}$ & $\begin{array}{c}\Delta t \\
(\mathrm{~min})\end{array}$ & $\begin{array}{c}\Delta \mathrm{M} \\
\text { Admix* } \\
\text { (R) }\end{array}$ & $\begin{array}{c}\text { Total } \\
\text { Deflation } \\
\left(8 / \mathrm{m}^{\wedge} 2-\mathrm{s}\right)\end{array}$ & $\begin{array}{c}\text { Wind } \\
\text { Speed } \\
\text { Category } \\
(\mathrm{m} / \mathrm{s}) \\
\end{array}$ & $\begin{array}{l}\text { Test } \\
\text { No. }\end{array}$ & $\begin{array}{l}\text { Wind } \\
\text { Speed } \\
(\mathrm{m} / \mathrm{s})\end{array}$ & $\begin{array}{c}\Delta t \\
(\mathrm{~min})\end{array}$ & $\begin{array}{c}\Delta \mathrm{M} \\
\text { Admix } \\
(\mathrm{g})\end{array}$ & $\begin{array}{c}\text { Total } \\
\text { Deflation } \\
\left(\mathrm{g} / \mathrm{m}^{\wedge} 2-\mathrm{s}\right) \\
\end{array}$ & $\begin{array}{c}\text { Wind } \\
\text { Speed } \\
\text { Category } \\
(\mathrm{m} / \mathrm{s})\end{array}$ \\
\hline 49.1 & 20.15 & 2.0 & .3 & $-9.8 \mathrm{E}-02$ & 20.00 & 57.1 & 19.82 & 2.0 & 0 & & 20.00 \\
\hline $4 j \cdot 2$ & 25.00 & 2.0 & 41 & $1.3 \mathrm{E}+00$ & 25.00 & 37.2 & 24.98 & 2.0 & 0 & - & 25.00 \\
\hline 49.3 & 20.06 & 2.0 & .111 & $-3.6 \mathrm{E}+00$ & 20.00 & 57.3 & 19.99 & 2.0 & 34 & $1.1 \mathrm{E}+00$ & 20.00 \\
\hline 49.4 & 24.95 & 2.0 & .16 & $-5.2 \mathrm{E}-01$ & 25.00 & $57-4$ & 24.99 & 2.0 & 90 & $2.9 \mathrm{E}+00$ & 25.00 \\
\hline 49.5 & 19.97 & 2.0 & 183 & $6.0 \mathrm{E}+00$ & 20.00 & 57.5 & 19.99 & 2.0 & 90 & $2.9 \mathrm{E}+00$ & 20.00 \\
\hline 49.6 & 24.98 & 2.0 & 884 & $2.9 \mathrm{E}+01$ & 25.00 & 37.6 & 24.93 & 2.0 & 134 & $4.4 E+\infty 0$ & 25.00 \\
\hline 49.7 & 20.10 & 2.0 & .89 & $-2.9 \mathrm{E}+00$ & 20.00 & 57.7 & 19.99 & 2.0 & 369 & $1.2 \mathrm{E}+01$ & 20.00 \\
\hline 49.8 & 24.83 & 2.0 & 802 & $2.6 \mathrm{E}+01$ & 25.00 & 57.8 & 24.75 & 2.0 & 2280 & $7.5 E+01$ & 25.00 \\
\hline 50.1 & 19.98 & 2.0 & .1 & $-3.3 \mathrm{E}-02$ & 20.00 & $58-1$ & 19.87 & 2.0 & 0 & & 20.00 \\
\hline 50.2 & 24.75 & 2.0 & .1 & $-3.3 \mathrm{E}-02$ & 25.00 & 58.2 & 24.95 & 2.0 & 0 & & 25.00 \\
\hline 50.3 & 20.04 & 2.0 & 0 & & 20.00 & $58-3$ & 20.19 & 2.0 & .1 & $-3.3 \mathrm{E}-02$ & 20.00 \\
\hline $50-4$ & 24.96 & 2.0 & 8 & $2.6 \mathrm{E}-01$ & 25.00 & $58-4$ & 25.10 & 2.0 & 7 & $2.3 \mathrm{E}-01$ & 25.00 \\
\hline 50.5 & 19.87 & 2.0 & 156 & $5.1 E+\infty 0$ & 20.00 & 58.5 & 20.15 & 2.0 & 29 & $9.5 \mathrm{E}-01$ & 20.00 \\
\hline $50-6$ & 24.78 & 2.0 & 922 & $3.0 \mathrm{E}+01$ & 25.00 & 58.6 & 24.90 & 2.0 & 545 & $1.8 \mathrm{E}+01$ & 25.00 \\
\hline \multirow[t]{2}{*}{50.7} & 19.90 & 2.0 & 2844 & $9.3 E+01$ & 20.00 & 58.7 & 19.93 & 2.0 & .80 & $.2 .6 \mathrm{E}+00$ & 20.00 \\
\hline & & & & & & 58.8 & 24.85 & 2.0 & 889 & $2.9 \mathrm{E}+01$ & 25.00 \\
\hline 51.1 & 20.06 & 2.0 & 0 & & 20.00 & & & & & & \\
\hline 51.2 & 24,94 & 2.0 & 0 & & 25.00 & 59.1 & 19.98 & 2.0 & 0 & & 20.00 \\
\hline 51.3 & 20.15 & 2.0 & 0 & & 20.00 & 59.2 & 25.07 & 2.0 & 0 & & 25.00 \\
\hline 514 & 24.98 & 2.0 & 3 & $9.8 \mathrm{E}-02$ & 25.00 & 59.3 & 20.04 & 2.0 & .1 & $-3.3 \mathrm{E}-02$ & 20.00 \\
\hline 51.5 & 20.04 & 2.0 & 421 & $1.4 \mathrm{E}+01$ & 20.00 & $59-4$ & 24.95 & 2.0 & 3 & $9.8 \mathrm{E}-02$ & 25.00 \\
\hline 51.6 & 24.60 & 2.0 & 1071 & $3.5 E+01$ & 25.00 & 59.5 & 20.05 & 2.0 & 27 & $8.8 \mathrm{E}-01$ & 20.00 \\
\hline \multirow[t]{2}{*}{51.7} & 19.70 & 2.0 & 3296 & $1.1 \mathrm{E}+02$ & 20.00 & 59.6 & 24.95 & 2.0 & 472 & $1.5 \mathrm{E}+01$ & 25.00 \\
\hline & & & & & & 59.7 & 19.97 & 2.0 & .92 & $-3.0 E+00$ & 20.00 \\
\hline 52.1 & 20.05 & 2.0 & 4 & $1.3 \mathrm{E}-01$ & 20.00 & 99.8 & 24.93 & 2.0 & 681 & $2.2 \mathrm{E}+01$ & 25.00 \\
\hline 52.2 & 24.80 & 2.0 & 9 & $2.9 \mathrm{E}-01$ & 25.00 & & & & & & \\
\hline 52.3 & 19.96 & 2.0 & 532 & $1.7 E+01$ & 20.00 & $60-1$ & 9.86 & 5.0 & 489 & $6.4 \mathrm{E}+\infty$ & 10.00 \\
\hline \multirow[t]{2}{*}{524} & 24.78 & 2.0 & 1739 & $5.7 E+01$ & 25.00 & $60-2$ & 14.78 & 5.0 & 2903 & $3.8 \mathrm{E}+01$ & 15.00 \\
\hline & & & & & & 60.3 & 20.00 & 1.0 & 2174 & $1.4 \mathrm{E}+02$ & 20.00 \\
\hline 53.1 & 19.97 & 2.0 & 2 & 6.5E-02 & 20.00 & & & & & & \\
\hline 53.2 & 25.01 & 2.0 & 6 & - $2.0 \mathrm{E}-01$ & 25.00 & 61.1 & 20.04 & 1.0 & 4276 & $2.8 \mathrm{E}+02$ & 20.00 \\
\hline 53.3 & 19.98 & 2.0 & 532 & $1.7 \mathrm{E}+01$ & 20.00 & & & & & & \\
\hline 53.4 & 25.02 & 2.0 & 1410 & $4.6 \mathrm{E}+01$ & 25.00 & 62.1 & 20.32 & 2.0 & .2 & $-6.5 \mathrm{E}-02$ & 20.00 \\
\hline 53.5 & 20.06 & 2.0 & 232 & $7.6 \mathrm{E}+\infty 0$ & 20.00 & 62.2 & 23.92 & 2.0 & 50 & $1.6 \mathrm{E}+00$ & 25.00 \\
\hline \multirow[t]{2}{*}{53.6} & 24.88 & 2.0 & 2043 & $6.7 \mathrm{E}+01$ & 25.00 & 62.3 & 19.90 & 2.0 & .36 & $-1.2 \mathrm{E}+\infty 0$ & 20.00 \\
\hline & & & & & & $62-4$ & 24.89 & 2.0 & 34 & $1.1 E+\infty$ & 25.00 \\
\hline 54.1 & 20.00 & 2.0 & 0 & & 20.00 & 62.5 & 20.00 & 2.0 & 131 & $4.3 \mathrm{E}+\infty$ & 20.00 \\
\hline $54-2$ & 25.14 & 2.0 & 0 & & 25.00 & 62.6 & 24.89 & 2.0 & 2016 & $6.6 \mathrm{E}+01$ & 25.00 \\
\hline 54.3 & 20.25 & 2.0 & .59 & $-1.9 \mathrm{E}+00$ & 20.00 & 62.7 & 19.96 & 2.0 & -11 & $-3.6 \mathrm{E}-01$ & 20.00 \\
\hline 544 & 24.92 & 2.0 & 3 & $9.8 \mathrm{E}-02$ & 25.00 & 62.8 & 24.90 & 2.0 & 611 & $2.0 \mathrm{E}+01$ & 25.00 \\
\hline 54.5 & 20.12 & 2.0 & 104 & $3.4 E+00$ & 20.00 & & & & & & \\
\hline $54-6$ & 24.81 & 2.0 & 1124 & $3.7 \mathrm{E}+01$ & 25.00 & $6 j .1$ & 19.95 & 2.0 & .1 & $-3.3 \mathrm{E}-02$ & 20.00 \\
\hline $54-7$ & 19.99 & 2.0 & .98 & $-3.2 E+00$ & 20.00 & 63.2 & 25.22 & 2.0 & 97 & $3.2 \mathrm{E}+00$ & 25.00 \\
\hline \multirow[t]{2}{*}{$54-8$} & 24.81 & 2.0 & 1283 & $4.2 \mathrm{E}+01$ & 25.00 & $63-3$ & 20.02 & 2.0 & .59 & $-1.9 \mathrm{E}+00$ & 20.00 \\
\hline & & & & & & $63-4$ & 24.94 & 2.0 & 66 & $2.2 \mathrm{E}+00$ & 25.00 \\
\hline 55.1 & 19.97 & 2.0 & 0 & & 20.00 & 63.5 & 19.98 & 2.0 & 164 & $5.4 E+\infty$ & 20.00 \\
\hline 35.2 & 25.06 & 2.0 & 0 & & 25.00 & 63.6 & 24.80 & 2.0 & 2275 & $7.4 \mathrm{E}+01$ & 25.00 \\
\hline 55.3 & 20.10 & 2.0 & 1 & $3.3 \mathrm{E}-02$ & 20.00 & 63.7 & 20.00 & 2.0 & -26 & $-8.5 \mathrm{E}-01$ & 20.00 \\
\hline $35-4$ & 25.00 & 2.0 & 16 & $5.2 \mathrm{E}-01$ & 25.00 & 63.8 & 25.00 & 2.0 & 841 & $2.7 E+01$ & 25.00 \\
\hline 55.5 & 20.00 & 2.0 & 54 & $1.8 \mathrm{E}+\infty 0$ & 20.00 & & & & & & \\
\hline \multirow[t]{2}{*}{$55-6$} & 24.91 & 2.0 & 2663 & 8.7E+01 & 25.00 & $64-1$ & 20.06 & 2.0 & 0 & & 20.00 \\
\hline & & & & & & 642 & 24.21 & 2.0 & 0 & & 25.00 \\
\hline $56-1$ & 20.04 & 2.0 & 0 & & 20.00 & $64 \cdot 3$ & 20.10 & 2.0 & 0 & & 20.00 \\
\hline 56.2 & 24.33 & 2.5 & 0 & & 25.00 & $64-4$ & 25.13 & 2.0 & .1 & $-3.3 \mathrm{E}-02$ & 25.00 \\
\hline $56-3$ & 20.21 & 2.0 & 30 & $9.8 \mathrm{E}-01$ & 20.00 & $64-5$ & 20.00 & 2.0 & 4 & $1.3 \mathrm{E}-01$ & 20.00 \\
\hline 564 & 25.39 & 2.0 & 85 & $2.8 \mathrm{E}+00$ & 25.00 & $64-6$ & 25.16 & 2.0 & 147 & $4.8 E+00$ & 25.00 \\
\hline 56.5 & 20.05 & 2.0 & 74 & $2.4 E+\infty 0$ & 20.00 & 647 & 20.01 & 2.0 & -61 & $-2.0 \mathrm{E}+00$ & 20.00 \\
\hline $56-6$ & 25.06 & 2.0 & 157 & $5.1 E+\infty$ & 25.00 & 64.8 & 25.09 & 2.0 & 9 & $-2.9 \mathrm{E}-01$ & 25.00 \\
\hline 56.7 & 20.08 & 2.0 & 347 & $1.1 \mathrm{E}+01$ & 20.00 & & & & & & \\
\hline 56.8 & 24.90 & 2.0 & 1408 & $4.6 \mathrm{E}+01$ & 25.00 & & & & & & \\
\hline
\end{tabular}

- Mass gains from exposure to saltating sand reported as negative (.) mass losses. 


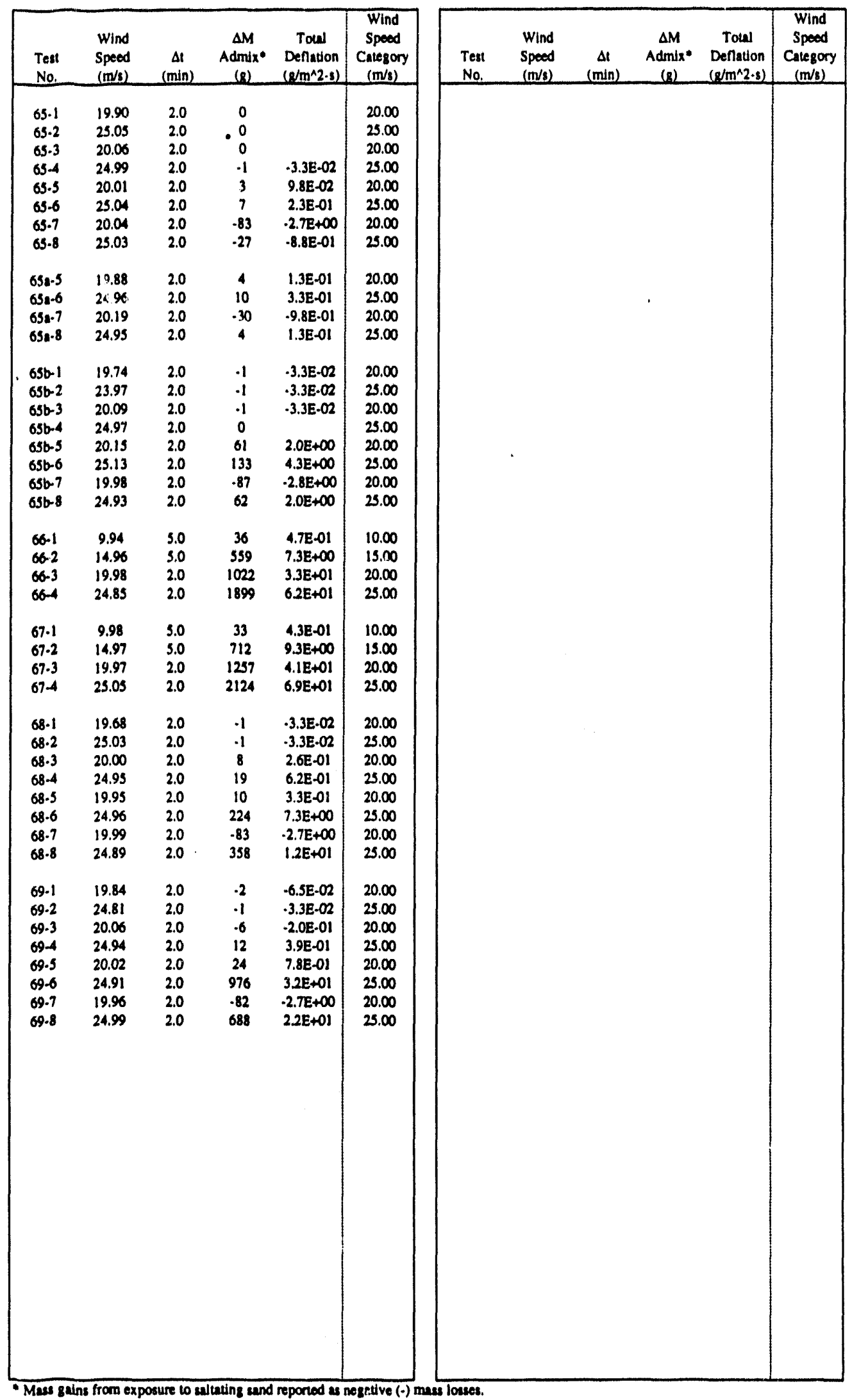




\section{APPENDIX A-B}

WIND EROSION TEST DATA GROUPED BY TEST PARAMETER 
Fix DRcontrol $7 / 93$

Surface Deflation $\left(g /\left(m^{\wedge} 2-s\right)\right)$ and Cumulative Mass Loss (g) Data Summary:

(Untreated Controls, Page 1 of 2)

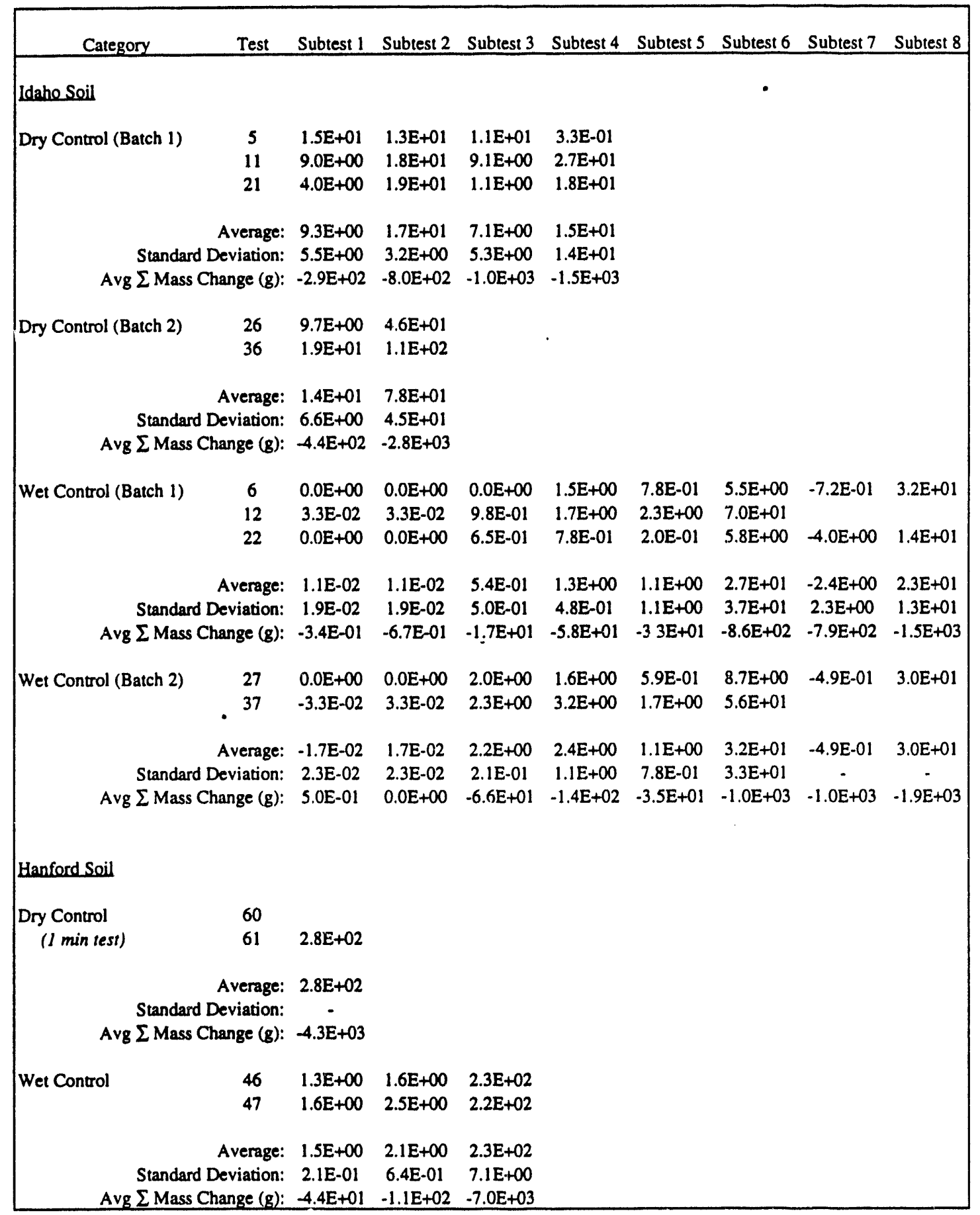


Fix DRcontrol $7 / 93$

Surface Deflation $\left(g /\left(m^{\wedge} 2-s\right)\right.$ and Cumulative Mass Loss ( $g$ ) Data Summary:

(Untreated Controls, Page 2 of 2)

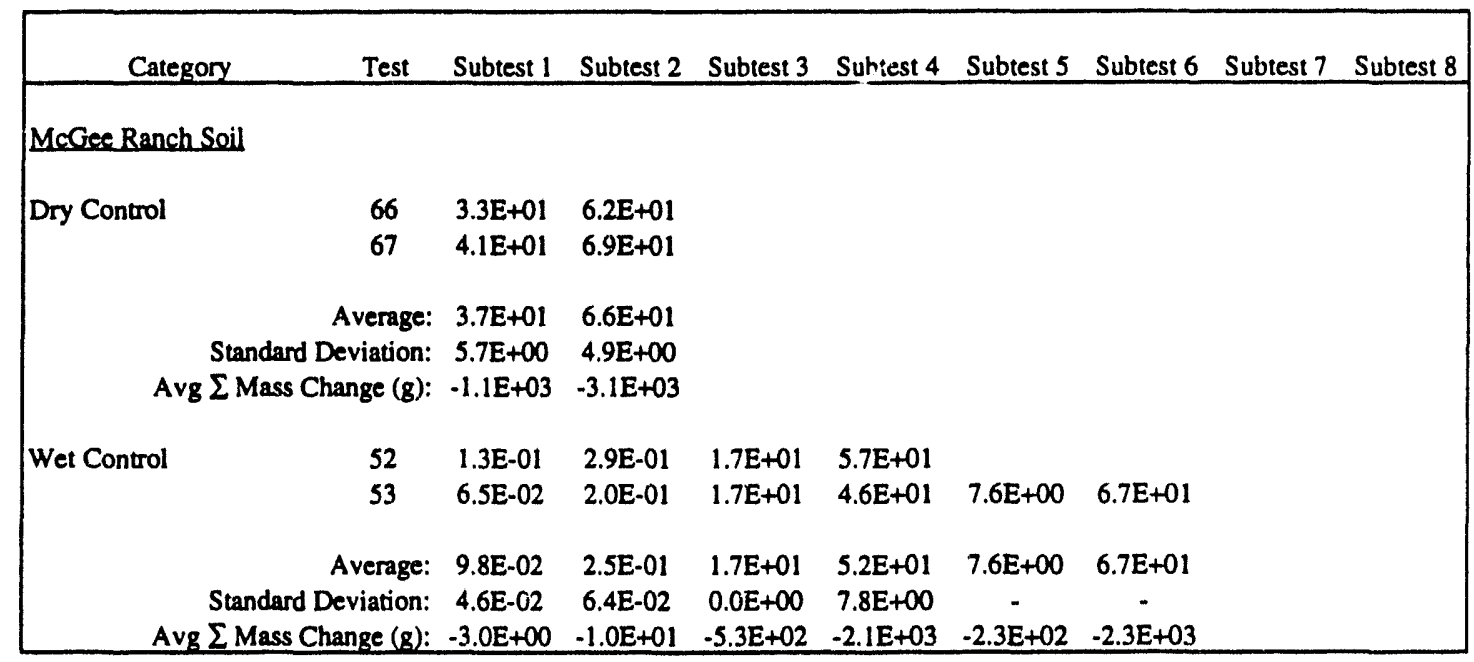




\begin{tabular}{|c|c|c|c|c|c|c|c|c|c|}
\hline Category & Test & Subtest 1 & Subtest 2 & Subtest 3 & Subtest 4 & Subtest 5 & Subtest 6 & Subtest 7 & Subtest 8 \\
\hline \multicolumn{10}{|c|}{ Idaho Soil/Potaro Starch } \\
\hline \multirow[t]{3}{*}{ P.S. $1 \% @ 1 \mathrm{~L} / \mathrm{m}^{\wedge} 2$} & 3 & $0.0 \mathrm{E}+00$ & $0.0 \mathrm{E}+00$ & $-1.9 \mathrm{E}+00$ & $-3.1 \mathrm{E}-01$ & $3.6 \mathrm{E}-01$ & $3.5 E+\infty 0$ & $-6.0 \mathrm{E}+00$ & $2.2 \mathrm{E}+01$ \\
\hline & 9 & $0.0 \mathrm{E}+00$ & $3.3 \mathrm{E}-02$ & $1.6 \mathrm{E}-01$ & $1.8 \mathrm{E}+00$ & $1.3 \mathrm{E}+00$ & $2.1 E+01$ & $-2.1 \mathrm{E}+01$ & $2.8 \mathrm{E}+01$ \\
\hline & 23 & 3.3E-02 & $0.0 \mathrm{E}+\infty$ & $-3.6 \mathrm{E}-01$ & $6.5 \mathrm{E}-02$ & $2.3 \mathrm{E}-01$ & $2.1 \mathrm{E}+00$ & $-5.6 \mathrm{E}+00$ & $6.1 \mathrm{E}+00$ \\
\hline \multirow{2}{*}{\multicolumn{2}{|c|}{$\begin{array}{r}\text { Average: } \\
\text { Standard Deviation: }\end{array}$}} & $1.1 \mathrm{E}-02$ & $1.1 \mathrm{E}-02$ & $-7.0 \mathrm{E}-01$ & $5.2 \mathrm{E}-01$ & $6.3 \mathrm{E}-01$ & $8.9 \mathrm{E}+00$ & $-1.1 \mathrm{E}+01$ & $1.9 E+01$ \\
\hline & & $1.9 \mathrm{E}-02$ & $1.9 \mathrm{E}-02$ & $1.1 \mathrm{E}+00$ & $1.1 E+00$ & $5.8 \mathrm{E}-01$ & $1.1 \mathrm{E}+01$ & $8.8 E+00$ & $1.1 \mathrm{E}+01$ \\
\hline \multicolumn{2}{|c|}{ Avg $\Sigma$ Mass Change (g): } & $-3.4 E-01$ & $-6.7 E-01$ & $2.1 \mathrm{E}+01$ & $4.9 \mathrm{E}+00$ & $-1.9 \mathrm{E}+01$ & $-2.9 \mathrm{E}+02$ & $4.2 \mathrm{E}+01$ & $-5.3 E+02$ \\
\hline \multirow[t]{2}{*}{ P.S. $190 @ 2 \mathrm{~L} / \mathrm{m}^{\wedge} 2$} & 7 & $-3.3 \mathrm{E}-02$ & $-3.3 \mathrm{E}-02$ & $-5.6 \mathrm{E}-01$ & $-1.6 \mathrm{E}-01$ & $1.1 \mathrm{E}+00$ & $4.8 \mathrm{E}+00$ & $-5.5 E+00$ & $4.6 \mathrm{E}+00$ \\
\hline & 13 & $0.0 \mathrm{E}+\infty 0$ & $0.0 \mathrm{E}+00$ & $-2.3 \mathrm{E}-01$ & $-1.6 \mathrm{E}-01$ & $7.8 \mathrm{E}-01$ & $5.5 \mathrm{E}+00$ & $-5.7 E+00$ & $9.7 \mathrm{E}+00$ \\
\hline \multirow{2}{*}{$\begin{array}{ll}" & \text { (Soil Batch 2) } \\
" \quad \text { (Soil Batch 2) }\end{array}$} & 28 & $-3.3 \mathrm{E}-02$ & $0.0 \mathrm{E}+00$ & $-1.3 \mathrm{E}-01$ & $-9.8 \mathrm{E}-02$ & $3.6 \mathrm{E}-01$ & $3.7 \mathrm{E}+00$ & $-5.8 E+00$ & $6.5 E+00$ \\
\hline & 29 & nd & nd & nd & nd & $9.8 \mathrm{E}-02$ & $2.5 \mathrm{E}+00$ & $-6.3 E+00$ & $5.5 E+00$ \\
\hline \multirow{2}{*}{\multicolumn{2}{|c|}{$\begin{array}{r}\text { Average: } \\
\text { Standard Deviation: }\end{array}$}} & $-2.2 \mathrm{E}-02$ & $-1.1 \mathrm{E}-02$ & $-3.1 E-01$ & $-1.4 \mathrm{E}-01$ & $5.8 \mathrm{E}-01$ & $4.1 E+\infty$ & $-5.8 \mathrm{E}+00$ & $6.6 \mathrm{E}+00$ \\
\hline & & $1.9 \mathrm{E}-02$ & $1.9 \mathrm{E}-02$ & 2.3E-01 & $3.6 \mathrm{E}-02$ & 4.4E-01 & $1.3 \mathrm{E}+00$ & $3.4 \mathrm{E}-01$ & $2.2 \mathrm{E}+00$ \\
\hline \multicolumn{2}{|c|}{ Avg $\sum$ Mass Change (g): } & $6.7 \mathrm{E}-01$ & $1.0 \mathrm{E}+00$ & $1.0 \mathrm{E}+01$ & $1.5 \mathrm{E}+01$ & $-1.8 E+01$ & $-1.4 \mathrm{E}+02$ & $3.4 \mathrm{E}+01$ & $-1.7 \mathrm{E}+02$ \\
\hline \multirow[t]{3}{*}{ P.S. $1 \% @ 4 \mathrm{~L} / \mathrm{m}^{\wedge} 2$} & 38 & $0.0 \mathrm{E}+00$ & $-3.3 \mathrm{E}-02$ & $-6.5 \mathrm{E}-02$ & $-9.8 \mathrm{E}-02$ & $9.5 \mathrm{E}-01$ & $6.6 \mathrm{E}+00$ & $-2.5 \mathrm{E}+00$ & $5.9 \mathrm{E}+00$ \\
\hline & 39 & $0.0 \mathrm{E}+\infty 0$ & $0.0 \mathrm{E}+\infty$ & $-9.8 \mathrm{E}-02$ & $-9.8 \mathrm{E}-02$ & $6.2 \mathrm{E}-01$ & $6.8 \mathrm{E}+00$ & $-3.6 \mathrm{E}+00$ & $6.4 E+00$ \\
\hline & Average: & $0.0 \mathrm{E}+00$ & $-1.7 \mathrm{E}-02$ & $-8.2 \mathrm{E}-02$ & $-9.8 \mathrm{E}-02$ & 7.9E-01 & $6.7 E+00$ & $-3.1 E+\infty 0$ & $6.2 E+00$ \\
\hline \multirow{2}{*}{\multicolumn{2}{|c|}{$\begin{array}{l}\text { Standard Deviation: } \\
\text { Avg } \Sigma \text { Mass Change (g): }\end{array}$}} & $0.0 \mathrm{E}+00$ & $2.3 \mathrm{E}-02$ & 2.3E-02 & $0.0 \mathrm{E}+00$ & 2.3E-01 & $1.4 \mathrm{E}-01$ & $7.8 \mathrm{E}-01$ & 3.5E-01 \\
\hline & & $0.0 \mathrm{E}+00$ & $5.0 \mathrm{E}-01$ & $3.0 \mathrm{E}+00$ & $6.0 \mathrm{E}+00$ & $-2.4 \mathrm{E}+01$ & $-2.3 E+02$ & $-1.4 \mathrm{E}+02$ & $-3.2 \mathrm{E}+02$ \\
\hline \multirow[t]{3}{*}{ P.S. $2.5 \% @ 1 \mathrm{~L} \mathrm{~m}^{\wedge} 2$} & 8 & $0.0 \mathrm{E}+00$ & $-3.3 \mathrm{E}-02$ & $-7.5 \mathrm{E}-01$ & $-1,6 \mathrm{E}-01$ & $1.3 \mathrm{E}-01$ & $1.1 \mathrm{E}+00$ & $-8.6 \mathrm{E}+00$ & $-1.3 \mathrm{E}+\infty$ \\
\hline & 17 & $0.0 \mathrm{E}+00$ & $0.0 \mathrm{E}+\infty$ & $-3.9 \mathrm{E}-01$ & $-1.3 \mathrm{E}-01$ & $9.8 \mathrm{E}-02$ & $1.5 \mathrm{E}+00$ & $-9.6 \mathrm{E}+00$ & $2.0 \mathrm{E}+\infty$ \\
\hline & Average: & $0.0 \mathrm{E}+00$ & & & & & $1.3 \mathrm{E}+00$ & $-9.1 E+00$ & $3.5 \mathrm{E}-01$ \\
\hline \multirow{2}{*}{\multicolumn{2}{|c|}{$\begin{array}{r}\text { Standard Deviation: } \\
\text { Avg } \sum \text { Mass Change (g): }\end{array}$}} & $0.0 \mathrm{E}+\infty 0$ & $2.3 \mathrm{E}-02$ & $2.5 \mathrm{E}-01$ & $2.1 \mathrm{E}-02$ & 2.3E-02 & $2.8 \mathrm{E}-01$ & 7.1E-01 & $2.3 \mathrm{E}+00$ \\
\hline & & $0.0 \mathrm{E}+00$ & $5.0 \mathrm{E}-01$ & $1.8 \mathrm{E}+01$ & $2.2 \mathrm{E}+01$ & $-3.5 E+00$ & $-4.3 \mathrm{E}+01$ & $2.4 \mathrm{E}+02$ & $2.2 \mathrm{E}+02$ \\
\hline \multirow[t]{3}{*}{ P.S. $2.5 \% @ 2 \mathrm{Lm}^{\wedge} 2$} & 15 & 3.3E-02 & $0.0 \mathrm{E}+00$ & $-3.3 \mathrm{E}-01$ & $-1.3 \mathrm{E}-01$ & $1.3 \mathrm{E}-01$ & $2.2 \mathrm{E}+00$ & $-8.9 \mathrm{E}+00$ & $-6.5 \mathrm{E}-02$ \\
\hline & 18 & $0.0 \mathrm{E}+00$ & $0.0 \mathrm{E}+00$ & $-7.2 \mathrm{E}-01$ & $-4.9 \mathrm{E}-01$ & $1.6 \mathrm{E}-01$ & $1.0 \mathrm{E}+00$ & $-8.2 \mathrm{E}+00$ & $-2.3 E+00$ \\
\hline & Average: & $1.7 \mathrm{E}-02$ & $0.0 \mathrm{E}+00$ & $-5.3 \mathrm{E}-01$ & $-3.1 E-01$ & $1.5 \mathrm{E}-01$ & $1.6 \mathrm{E}+100$ & $-8.6 \mathrm{E}+00$ & $-1.2 \mathrm{E}+00$ \\
\hline \multirow{2}{*}{\multicolumn{2}{|c|}{$\begin{array}{l}\text { Standard Deviation: } \\
\text { Avg } \sum \text { Mass Change (g): }\end{array}$}} & $2.3 \mathrm{E}-02$ & $0.0 \mathrm{E}+\infty 0$ & $2.8 \mathrm{E}-01$ & 2.5E-01 & 2.1E-02 & 8.5E-01 & $4.9 \mathrm{E}-01$ & $1.6 \mathrm{E}+\infty$ \\
\hline & & $-5 . C E-01$ & $-5.0 \mathrm{E}-01$ & $1.6 \mathrm{E}+01$ & $2.5 \mathrm{E}+01$ & $-4.4 E+\infty$ & $-5.3 \mathrm{E}+01$ & $2.1 E+02$ & $2.4 \mathrm{E}+02$ \\
\hline \multirow[t]{2}{*}{ P.S. $2.5 \% @ 4 \mathrm{~L} / \mathrm{m}^{\wedge} 2$} & 4 & $3.312-02$ & $0.0 \mathrm{E}+00$ & $-7.2 \mathrm{E}-01$ & $-4.2 \mathrm{E}-01$ & $3.9 \mathrm{E}-01$ & $3.3 \mathrm{E}+\infty 0$ & $-9.4 \mathrm{E}+00$ & $-2.2 \mathrm{E}+00$ \\
\hline & 10 & $0.0 \mathrm{E}+00$ & $0.0 \mathrm{E}+00$ & $-7.2 \mathrm{E}-01$ & $-5.6 \mathrm{E}-01$ & $5.6 \mathrm{E}-01$ & $3.9 E+00$ & $-7.2 E+00$ & $-2.2 \mathrm{E}+00$ \\
\hline \multirow{3}{*}{\multicolumn{2}{|c|}{ Avg $\sum$ Mass Change (g): }} & $1.7 \mathrm{E}-02$ & $0.0 \mathrm{E}+00$ & & $-4.9 \mathrm{E}-01$ & 4.8E-01 & $3.6 \mathrm{E}+00$ & $-8.3 E+00$ & $-2.2 \mathrm{E}+00$ \\
\hline & & 2.3E-02 & $0.0 \mathrm{E}+00$ & & $9.9 \mathrm{E}-02$ & $1.2 \mathrm{E}-01$ & 4.2E-01 & $1.6 \mathrm{E}+00$ & $0.0 \mathrm{E}+00$ \\
\hline & & $-5.0 \mathrm{E}-01$ & $-5.0 \mathrm{E}-01$ & $2.2 \mathrm{E}+01$ & $3.7 \mathrm{E}+01$ & $-1.5 \mathrm{E}+01$ & $-1.2 \mathrm{E}+02$ & $1.3 \mathrm{E}+02$ & $2.0 \mathrm{E}+02$ \\
\hline P.S. $1 \% @ 2 L / m^{\wedge} 2$ & 14 & $0.0 \mathrm{E}+00$ & $0.0 \mathrm{E}+00$ & $-2.6 \mathrm{E}-01$ & $-1.3 \mathrm{E}-01$ & 4.2E-01 & $3.4 \mathrm{E}+\infty 0$ & $-5.8 \mathrm{E}+00$ & $5.9 \mathrm{E}+00$ \\
\hline \multirow[t]{2}{*}{ (uv-cycling tests) } & 16 & $0.0 \mathrm{E}+\infty 0$ & $0.0 \mathrm{E}+00$ & $-1.6 \mathrm{E}-01$ & $-3.3 \mathrm{E}-02$ & $1.3 \mathrm{E}-01$ & $1.3 \mathrm{E}+00$ & $-8.6 \mathrm{E}+00$ & $3.0 \mathrm{E}+00$ \\
\hline & Average: & $0.0 \mathrm{E}+\infty 0$ & $0.0 \mathrm{E}+00$ & $-2.1 \mathrm{E}-01$ & $-8.2 E-02$ & $2.8 \mathrm{E}-01$ & $2.4 \mathrm{E}+00$ & $-7.2 \mathrm{E}+00$ & $4.5 \mathrm{E}+00$ \\
\hline \multirow{2}{*}{\multicolumn{2}{|c|}{ Avg $\sum$ Mass Change (g): }} & $0.0 \mathrm{E}+00$ & $0.0 \mathrm{E}+00$ & 7.1E-02 & $6.9 \mathrm{E}-02$ & 2.1E-01 & $1.5 E+00$ & $2.0 \mathrm{E}+00$ & $2.1 \mathrm{E}+\infty$ \\
\hline & & $0.0 \mathrm{E}+00$ & $0.0 \mathrm{E}+\infty 0$ & $6.4 \mathrm{E}+\infty 0$ & $8.9 \mathrm{E}+00$ & $-8.4 \mathrm{E}+00$ & $-8.0 \mathrm{E}+01$ & $1.4 \mathrm{E}+02$ & $3.8 \mathrm{E}+\infty 0$ \\
\hline
\end{tabular}


Fix DRps $7 / 93$

Surface Deflation ( $g /\left(m^{\wedge} 2-s\right)$ and Cumulative Mass Loss $(g)$ Data Summary:

(Potato Starch, Page 2 of 2)

\begin{tabular}{|c|c|c|c|c|c|c|c|c|c|}
\hline Category & Test & Subtest 1 & Subtest 2 & Subtest 3 & Subtest 4 & Subtest 5 & Subtest 6 & Subtest 7 & Subtest 8 \\
\hline P.S. $1 \% @ 2 \mathrm{~L} / \mathrm{m}^{\wedge} 2$ & 19 & $0.0 \mathrm{E}+\infty 0$ & $0.0 \mathrm{E}+00$ & $-1.3 \mathrm{E}-01$ & $-9.8 \mathrm{E}-02$ & $1.0 \mathrm{E}+00$ & $2.9 E+01$ & $4.6 \mathrm{E}-01$ & $4.2 \mathrm{E}+01$ \\
\hline (Moisture-cycling tests) & 20 & 3.3E-02 & 3.3E-02 & $-9.8 \mathrm{E}-02$ & 3.3E-02 & 8.5E-01 & $3.2 \mathrm{E}+01$ & $1.3 \mathrm{E}-01$ & $3.3 \mathrm{E}+01$ \\
\hline \multirow{2}{*}{\multicolumn{2}{|c|}{ Standard Deviation: }} & $1.7 \mathrm{E}-02$ & $1.7 \mathrm{E}-02$ & $-1.1 \mathrm{E}-01$ & $-3.3 \mathrm{E}-02$ & 9.3E-01 & $3.1 \mathrm{E}+01$ & $3.0 \mathrm{E}-01$ & $3.8 \mathrm{E}+01$ \\
\hline & & 2.3E-02 & 2.3E-02 & 2.3E-02 & $9.3 E-02$ & $1.1 \mathrm{E}-01$ & $2.1 E+00$ & 2.3E-01 & $6.4 \mathrm{E}+00$ \\
\hline \multicolumn{2}{|c|}{ Avg $\Sigma$ Mass Change (g): } & $-5.0 \mathrm{E}-01$ & $-1.0 \mathrm{E}+00$ & $2.5 \mathrm{E}+00$ & $3.5 \mathrm{E}+00$ & $-2.8 \mathrm{E}+01$ & $-9.6 \mathrm{E}+02$ & $-9.7 \mathrm{E}+02$ & $-2.1 E+03$ \\
\hline \multicolumn{10}{|c|}{ Hanford Sandy Soil/Potate Starch } \\
\hline \multirow[t]{3}{*}{ P.S. $1 \% @ 2 L / m^{\wedge} 2$} & 50 & $-3.3 E-02$ & $-3.3 E-02$ & $0.0 \mathrm{E}+00$ & $2.6 E-01$ & $5.1 E+\infty$ & $3.0 \mathrm{E}+01$ & $9.3 \mathrm{E}+01$ & \\
\hline & 51 & $0.0 \mathrm{E}+00$ & $0.0 \mathrm{E}+\infty$ & $0.0 \mathrm{E}+\infty$ & $9.8 \mathrm{E}-02$ & $1.4 \mathrm{E}+01$ & $3.5 E+01$ & $1.1 \mathrm{E}+02$ & \\
\hline & Average: & $-1.7 \mathrm{E}-02$ & $-1.7 \mathrm{E}-02$ & $0.0 \mathrm{E}+00$ & $1.8 \mathrm{E}-01$ & $9.6 \mathrm{E}+00$ & $3.3 \mathrm{E}+01$ & $1.0 \mathrm{E}+02$ & \\
\hline \multicolumn{2}{|c|}{ Standand Deviation: } & $2.3 \mathrm{E}-02$ & 2.3E-02 & $0.0 \mathrm{E}+00$ & $1.1 \mathrm{E}-01$ & $6.3 E+00$ & $3.5 \mathrm{E}+00$ & $1.2 \mathrm{E}+01$ & \\
\hline \multicolumn{2}{|c|}{ Avg $\sum$ Mass Change (g): } & $5.0 \mathrm{E}-01$ & $1.0 E+00$ & $1.0 \mathrm{E}+00$ & $-4.5 E+00$ & $-2.9 \mathrm{E}+02$ & $-1.3 E+03$ & $-4.4 E+03$ & \\
\hline
\end{tabular}


Fix DRxdca $7 / 93$

Surface Deflation $\left(g /\left(m^{\wedge} 2-s\right)\right)$ and Cumulative Mass Loss ( $g$ ) Data Summary:

(XDCA, Page 1 of 1)

\begin{tabular}{|c|c|c|c|c|c|c|c|c|c|}
\hline Category & Test & Subtest 1 & Subtest 2 & Subtest 3 & Subtest 4 & Subtest 5 & Subtest 6 & Subtest 7 & Subtest 8 \\
\hline \multicolumn{10}{|l|}{ Idaho SoilXXDCA } \\
\hline \multirow[t]{2}{*}{$1: 1 @ 4.5 \mathrm{~L} / \mathrm{m}^{\wedge} 2$} & $\begin{array}{l}31 \\
33\end{array}$ & $\begin{array}{l}0.0 \mathrm{E}+00 \\
0.0 \mathrm{E}+00\end{array}$ & $\begin{array}{l}0.0 \mathrm{E}+00 \\
6.5 \mathrm{E}-02\end{array}$ & $\begin{array}{l}2.3 \mathrm{E}-01 \\
1.7 \mathrm{E}+\infty\end{array}$ & $\begin{array}{l}1.3 \mathrm{E}-01 \\
2.2 \mathrm{E}+00\end{array}$ & $\begin{array}{l}1.7 \mathrm{E}+00 \\
3.1 \mathrm{E}+\infty\end{array}$ & $\begin{array}{l}3.2 E+01 \\
5.1 E+01\end{array}$ & $\begin{array}{l}-3.9 \mathrm{E}-01 \\
-2.3 \mathrm{E}-01\end{array}$ & $\begin{array}{l}1.5 \mathrm{E}+01 \\
2.1 \mathrm{E}+01\end{array}$ \\
\hline & Average: & $0.0 \mathrm{E}+00$ & $3.3 \mathrm{E}-02$ & $9.7 \mathrm{E}-01$ & $1.2 \mathrm{E}+00$ & $2.4 E+00$ & $4.2 \mathrm{E}+01$ & $-3.1 \mathrm{E}-01$ & $1.8 \mathrm{E}+01$ \\
\hline \multirow{2}{*}{\multicolumn{2}{|c|}{$\begin{array}{l}\text { Standard Deviacion: } \\
\text { Avg } \sum \text { Mass Change (g): }\end{array}$}} & $0.0 \mathrm{E}+\infty 0$ & $4.6 \mathrm{E}-02$ & $1.0 \mathrm{E}+00$ & $1.5 \mathrm{E}+00$ & $9.9 \mathrm{E}-01$ & $1.3 \mathrm{E}+01$ & $1.1 \mathrm{E}-01$ & $4.2 \mathrm{E}+00$ \\
\hline & & $0.0 \mathrm{E}+00$ & $-9.9 \mathrm{E}-01$ & $-3.1 E+01$ & $-6.6 \mathrm{E}+01$ & $-7.3 E+01$ & $-1.3 E+03$ & $-1.3 \mathrm{E}+03$ & $-1.9 \mathrm{E}+03$ \\
\hline \multirow[t]{2}{*}{$1: 2 @ 1.1 \mathrm{~L} / \mathrm{m}^{\wedge} 2$} & 25 & $9.8 \mathrm{E}-02$ & $4.6 \mathrm{E}-01$ & $2.3 E+01$ & $4.0 \mathrm{E}+01$ & & & & \\
\hline & 32 & $3.3 \mathrm{E}-02$ & $2.0 \mathrm{E}-01$ & $2.2 \mathrm{E}+01$ & $3.7 \mathrm{E}+0 !$ & & & & \\
\hline \multirow{3}{*}{\multicolumn{2}{|c|}{$\begin{array}{r}\text { Average: } \\
\text { Standard Deviation: } \\
\text { Avg } \sum \text { Mass Change (g): }\end{array}$}} & $6.6 \mathrm{E}-02$ & $3.3 \mathrm{E}-01$ & $2.3 \mathrm{E}+01$ & $3.9 \mathrm{E}+01$ & & & & \\
\hline & & $4.6 \mathrm{E}-02$ & $1.8 \mathrm{E}-01$ & 7.1F-01 & $2.1 E+00$ & & & & \\
\hline & & $-2.0 \mathrm{E}+00$ & $-1.2 \mathrm{E}+01$ & $-7.0 \mathrm{E}+02$ & $-1.9 \mathrm{E}+03$ & & & & \\
\hline \multirow[t]{2}{*}{$1: 2 @ 4.5 \mathrm{~L} / \mathrm{m}^{\wedge} 2$} & 24 & $0.0 \mathrm{E}+00$ & $0.0 \mathrm{E}+00$ & $1.3 E+\infty 0$ & $1.2 \mathrm{E}+00$ & $4.3 \mathrm{E}+00$ & $5.4 \mathrm{E}+01$ & & \\
\hline & 30 & $0.0 E+0.1$ & $3.3 \mathrm{E}-02$ & $7.5 \mathrm{E}-01$ & $5.2 \mathrm{E}-01$ & $2.3 \mathrm{E}+00$ & $5.8 \mathrm{E}+01$ & & \\
\hline \multirow{3}{*}{\multicolumn{2}{|c|}{$\begin{array}{r}\text { Average: } \\
\text { Standard Deviation: } \\
\text { Avg } \sum \text { Mass Change }(\mathrm{g}):\end{array}$}} & $0.0 \mathrm{E}+\infty 0$ & $1.7 \mathrm{E}-02$ & $1.0 \mathrm{E}+\infty 0$ & $8.6 \mathrm{E}-01$ & $3.3 E+\infty 0$ & $5.6 \mathrm{E}+01$ & & \\
\hline & & $0.0 \mathrm{E}+\infty 0$ & 2.3E-02 & $3.9 \mathrm{E}-01$ & $4.8 \mathrm{E}-01$ & $1.4 \mathrm{E}+00$ & $2.8 E+\infty 0$ & & \\
\hline & & $0.0 \mathrm{E}+00$ & $-5.0 \mathrm{E}-01$ & $-3.2 \mathrm{E}+01$ & $-5.8 \mathrm{E}+01$ & $-1.0 \mathrm{E}+02$ & $-1.8 \mathrm{E}+03$ & & \\
\hline \multirow[t]{2}{*}{$1: 2 @ 9.2 \mathrm{Lm}^{\wedge} 2$} & 40 & $6.5 \mathrm{E}-02$ & $0.0 \mathrm{E}+\infty 0$ & $2.9 \mathrm{E}-01$ & $-3.3 \mathrm{E}-02$ & $1.8 \mathrm{E}+00$ & $2.6 \mathrm{E}+01$ & & $6.5 \mathrm{E}+00$ \\
\hline & 41 & $0.0 \mathrm{E}+00$ & $6.5 \mathrm{E}-02$ & $-3.3 \mathrm{E}-02$ & $6.5 \mathrm{E}-02$ & $1.1 \mathrm{E}+00$ & $3.0 \mathrm{E}+01$ & $-1.3 \mathrm{E}-01$ & $9.4 \mathrm{E}+00$ \\
\hline \multirow{3}{*}{\multicolumn{2}{|c|}{$\begin{array}{r}\text { Average: } \\
\text { Standard Deviation: } \\
\text { Avg } \sum \text { Mass Change (g): }\end{array}$}} & $3.3 \mathrm{E}-02$ & $3.3 \mathrm{E}-02$ & $1.3 \mathrm{E}-01$ & $1.6 \mathrm{E}-02$ & $1.5 \mathrm{E}+00$ & $2.8 \mathrm{E}+01$ & $-1.3 \mathrm{E}-01$ & $8.0 \mathrm{E}+00$ \\
\hline & & $4.6 \mathrm{E}-02$ & $4.6 \mathrm{E}-02$ & 2.3E-01 & $6.9 \mathrm{E}-02$ & 4.9E-01 & $2.8 \mathrm{E}+00$ & - & $2.1 E+00$ \\
\hline & & $-9.9 \mathrm{E}-01$ & $-2.0 \mathrm{E}+00$ & $-5.9 E+00$ & $-6.4 \mathrm{E}+00$ & $-4.4 \mathrm{E}+01$ & $-9.0 \mathrm{E}+02$ & $-9.0 \mathrm{E}+02$ & $-1.1 \mathrm{E}+03$ \\
\hline $1: 2 @ 4.5 \mathrm{~L} \mathrm{~m}^{\wedge} 2$ & 34 & $0.0 \mathrm{E}+00$ & $9.8 \mathrm{E}-02$ & $5.1 E+00$ & $9.4 \mathrm{E}+\infty 0$ & $1.6 \mathrm{E}+\infty 0$ & $3.7 \mathrm{E}+01$ & & \\
\hline (uv-cycling tests) & 35 & $0.0 \mathrm{E}+00$ & $6.5 \mathrm{E}-02$ & $3.3 E+00$ & $5.8 E+00$ & $9.5 \mathrm{E}-01$ & $4.1 E+01$ & & \\
\hline \multirow{3}{*}{\multicolumn{2}{|c|}{$\begin{array}{l}\text { Standard Deviation: } \\
\text { Avg } \sum \text { Mass Change (g): }\end{array}$}} & $0.0 \mathrm{E}+00$ & $8.2 \mathrm{E}-02$ & $4.2 \mathrm{E}+00$ & $7.6 \mathrm{E}+00$ & $1.3 \mathrm{E}+00$ & $3.9 \mathrm{E}+01$ & & \\
\hline & & $0.0 \mathrm{E}+00$ & 2.3E-02 & $1.3 \mathrm{E}+00$ & $2.5 E+00$ & $4.6 \mathrm{E}-01$ & $2.8 E+00$ & & \\
\hline & & $0.0 \mathrm{E}+\infty 0$ & $-2.5 E+00$ & $-1.3 \mathrm{E}+02$ & $-3.6 \mathrm{E}+02$ & $-3.9 E+01$ & $-1.2 \mathrm{E}+03$ & & \\
\hline $1: 2 @ 4.5 \mathrm{~L} \mathrm{~m}^{\wedge} 2$ & 44 & $3.3 \mathrm{E}-02$ & $1.3 \mathrm{E}-01$ & $1.6 \mathrm{E}+00$ & $4.9 \mathrm{E}+00$ & $4.1 E+\infty 0$ & 4.7E+01 & & \\
\hline \multirow[t]{2}{*}{ (Moisture-cycling tests) } & 45 & $0.0 \mathrm{E}+00$ & 3.3E-02 & $1.1 \mathrm{E}+\infty$ & $2.0 \mathrm{E}+00$ & $3.3 \mathrm{E}+00$ & $5.3 E+01$ & & \\
\hline \multirow{3}{*}{\multicolumn{2}{|c|}{$\begin{array}{l}\text { Average: } \\
\text { Standard Deviation: } \\
\text { Avg } \Sigma \text { Mass Change (g): }\end{array}$}} & $1.7 \mathrm{E}-02$ & $8.2 \mathrm{E}-02$ & $1.4 \mathrm{E}+00$ & $3.5 E+\infty 0$ & $3.7 \mathrm{E}+\infty 0$ & $5.0 \mathrm{E}+01$ & & \\
\hline & & $2.3 \mathrm{E}-02$ & $6.9 \mathrm{E}-02$ & $3.5 \mathrm{E}-01$ & $2.1 E+00$ & $5.7 \mathrm{E}-01$ & $4.2 \mathrm{E}+00$ & & \\
\hline & & $-5.0 \mathrm{E}-01$ & $-3.0 \mathrm{E}+\infty 0$ & $-4.4 E+01$ & $-1.5 E+02$ & $-1.1 E+02$ & $-1.6 \mathrm{E}+03$ & & \\
\hline \multicolumn{3}{|l|}{ Hanford SoilLXDCA } & & & & & & & \\
\hline \multirow[t]{2}{*}{$1: 2 @ 4.5 \mathrm{~L} / \mathrm{m}^{\wedge} 2$} & 64 & $0.0 \mathrm{E}+00$ & $0.0 \mathrm{E}+00$ & $0.0 \mathrm{E}+00$ & $-3.3 \mathrm{E}-02$ & $1.3 \mathrm{E}-01$ & $4.8 \mathrm{E}+00$ & $-2.0 \mathrm{E}+00$ & $-2.9 \mathrm{E}-01$ \\
\hline & 65 & $0.0 \mathrm{E}+\infty$ & $0.0 \mathrm{E}+\infty$ & $0.0 \mathrm{E}+00$ & $-3.3 \mathrm{E}-02$ & $9.8 \mathrm{E}-02$ & 2.3E-01 & $-2.7 E+00$ & $-8.8 \mathrm{E}-01$ \\
\hline \multirow{3}{*}{$\begin{array}{l}\text { (not included in avg...) } \\
\text { (not included in avg...) }\end{array}$} & $65 a$ & nd & nd & nd & nd & $1.3 E-01$ & $3.3 E-01$ & $-9.8 E-01$ & $1.3 E-01$ \\
\hline & $65 b$ & $\cdot 3.3 E \cdot 02$ & $\cdot 3.3 E-02$ & $-3.3 E-02$ & $0.0 E+\infty 0$ & $2.0 E+\infty 0$ & $4.3 E+\infty 0$ & $-2.8 E+\infty 0$ & $2.0 E+\infty 0$ \\
\hline & Average: & $0.0 \mathrm{E}+00$ & $0.0 \mathrm{E}+00$ & $0.0 \mathrm{E}+00$ & $-3.3 \mathrm{E}-02$ & $1.1 \mathrm{E}-01$ & $2.5 E+00$ & $-2.4 \mathrm{E}+00$ & $-5.9 \mathrm{E}-01$ \\
\hline \multirow{2}{*}{\multicolumn{2}{|c|}{$\begin{array}{l}\text { Standard Deviation: } \\
\text { Avg } \sum \text { Mass Change (g): }\end{array}$}} & $0.0 \mathrm{E}+\infty$ & $0.0 \mathrm{E}+\infty 0$ & $0.0 \mathrm{E}+00$ & $0.0 \mathrm{E}+00$ & 2.3E-02 & $3.2 \mathrm{E}+00$ & $4.9 \mathrm{E}-01$ & $4.2 \mathrm{E}-01$ \\
\hline & & $0.0 \mathrm{E}+\infty$ & $0.0 \mathrm{E}+\infty$ & $0.0 \mathrm{E}+00$ & $1.0 \mathrm{E}+00$ & $-3.5 \mathrm{E}+00$ & $-8.0 \mathrm{E}+01$ & $-8.5 \mathrm{E}+00$ & $9.4 \mathrm{E}+00$ \\
\hline
\end{tabular}


Fix DRfpw $7 / 93$

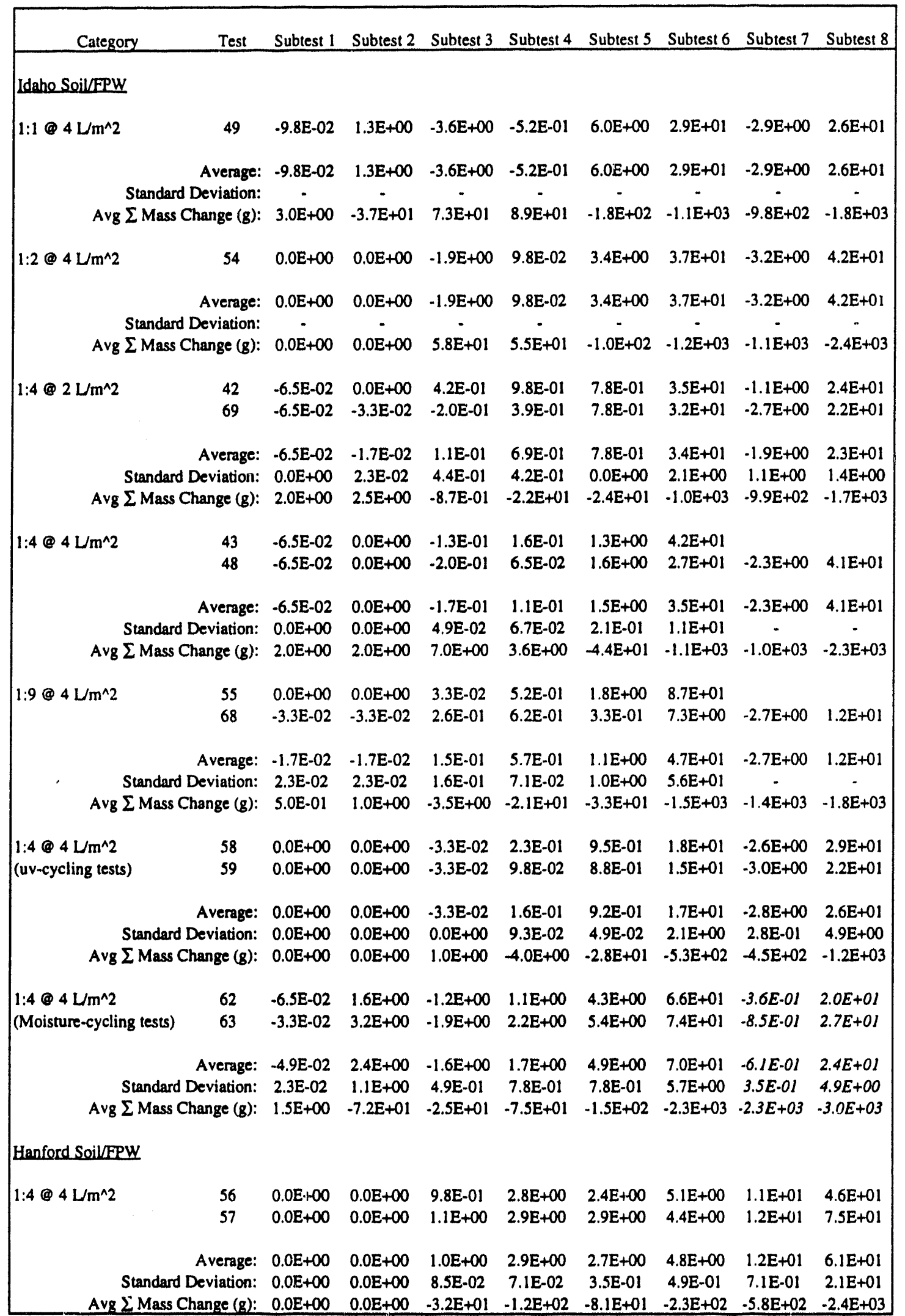




\section{DISTRIBUTION}

No. of

Copies

\section{OFFSITE}

2 DOE/Office of Scientific and

Technical Information

\section{ONSITE}

3 DOE Richland Field Office

J. D. Goodenough

R. D. Izatt

R. K. Stewart

2 Westinghouse Hanford Company

M. R. Sackschewsky

N. R. Wing

16 Pacific Northwest Laboratory

G. W. Dennis

M. W. Ligotke (6)

G. W. Gee

S. L. Friant Publishing Coordination

Technical Report Files (5)

\section{Routing (1 copy)}

\section{J. Graharn}

R. L. Skaggs

C. S. Sloane

P. M. Irving

C. J. Hostetler

R. M. Ecker

P. C. Hays (last)
No. of

Copies 
WHC-EP-0688

\section{DISTRIBUTION}

Number of Copies

OFFSITE

29

U.S. Department of EnergyHeadquarters

Washington, D.C. 20585

C. W. Frank

J. M. Lankford

J. Mohiuddin

P. Ritzcoben

U.S. Department of EnerqyRocky Flats Office

DOE Building 116

Golden, Colorado 80402-0464

R. Tyler

U.S. Department of Energy-Idaho Idaho Field Office 785 DOE Place

Idaho Falls, Idaho 83402

S. Hinschberger

T. Safford

G. H. Schneider

U.S. Department of Energy-Nevada Nevada Field Office

P.0. Box 98518

Las Vegas, Nevada 89193-8518

K. McWilliam

BWID Retrieval Technical Support Group Colorado School of Mines

Golden, Colorado 80401

R. King 
WHC-EP-0688

DISTRIBUTION (cont.)

EG\&G Idaho

P.0. Box 1625

Idaho Falls, Idaho 83415

R. W. Bonnenberg

B. M. Gardner

R. E. Heard

K. M. Kostelnik

G. Loomis

L. M. Milam

D. N. Thompson

M. R. Winberg

V. E. Wixom

D. McKenzie

EG\&G Rocky Flats. Inc.

Technology Development

P.0. Box 464

Golden, Colorado 80402-0464

J. Peterson

EG\&G-Nevada

Energy Measurements, Inc.

P.0. Box 1912

Las Vegas, Nevada 89125

L. Rogers

RSL-11

Lawrence Livermore National Laboratory

Environmental Restoration/Waste Management P.0. Box 808

Livermore, California 94550

J. L. Yow, Jr

Los Alamos National Laboratory

P.0. Box 1663,

Los Alamos, New Mexico 87454

G. Eller

$J 519$

H. Murphy

D446

Distr-2 
WHC-EP-0688

DISTRIBUTION (cont.)

Mason \& Hanger-Silas Mason Company

P.0. Box 30020

Amarillo, Texas 79177

A. C. Teter

Oak Ridge National Laboratory

P.0. Box 2008, MS 6304

Oak Ridge, Tennessee 37831-6304

B. Burks

6304

Sandia National Laboratory

P.0. Box 5800

Albuquerque, New Mexico 18185

N. Prindle

ONSITE

U.S. Department of EnerqyRichland Field office

D. Trader

$\mathrm{K} 8-50$

Public Reading Room

Al-65

Kaiser Engineering. Hanford

H. Dugger

E6-64

Pacific Northwest Laboratory

G. Carter

P7-01

M. W. Ligotke

P7-54

M. Peterson

P7-41

S. Siate

K1-19

PNL Technical files

$\mathrm{K} 1-11$

Westinghouse Hanford Company

\section{R. Adams}

R. Bauer

H6-01

J. D. Berger

L6-37

G. Berl in

LO-18

J. W. Cammann

LO-18

D. L. Crockford

H4- 14

D. J. Flesher

J. M. Frain

R. W. Powell

H4-14

L4-73

H6-04

W. M. Hayward

H4-14

R2-77

Distr-3 
WHC-EP-0688

\section{DISTRIBUTION (cont.)}

C. J. Kemp

H4-14

C. H. Kindle

H6-05

M. K. Korenko

B3-08

M. J. Lauterbach

S. J. Phillips

H6-01

M. R. Sackschewsky

H4-14

D. L. Smith

J. C. Sonnichsen

H4-14

J. Womack

J. G. Wool ard

Central Files

Information Release

Administration

H4-14

H6-05

L8-04

H4-17 


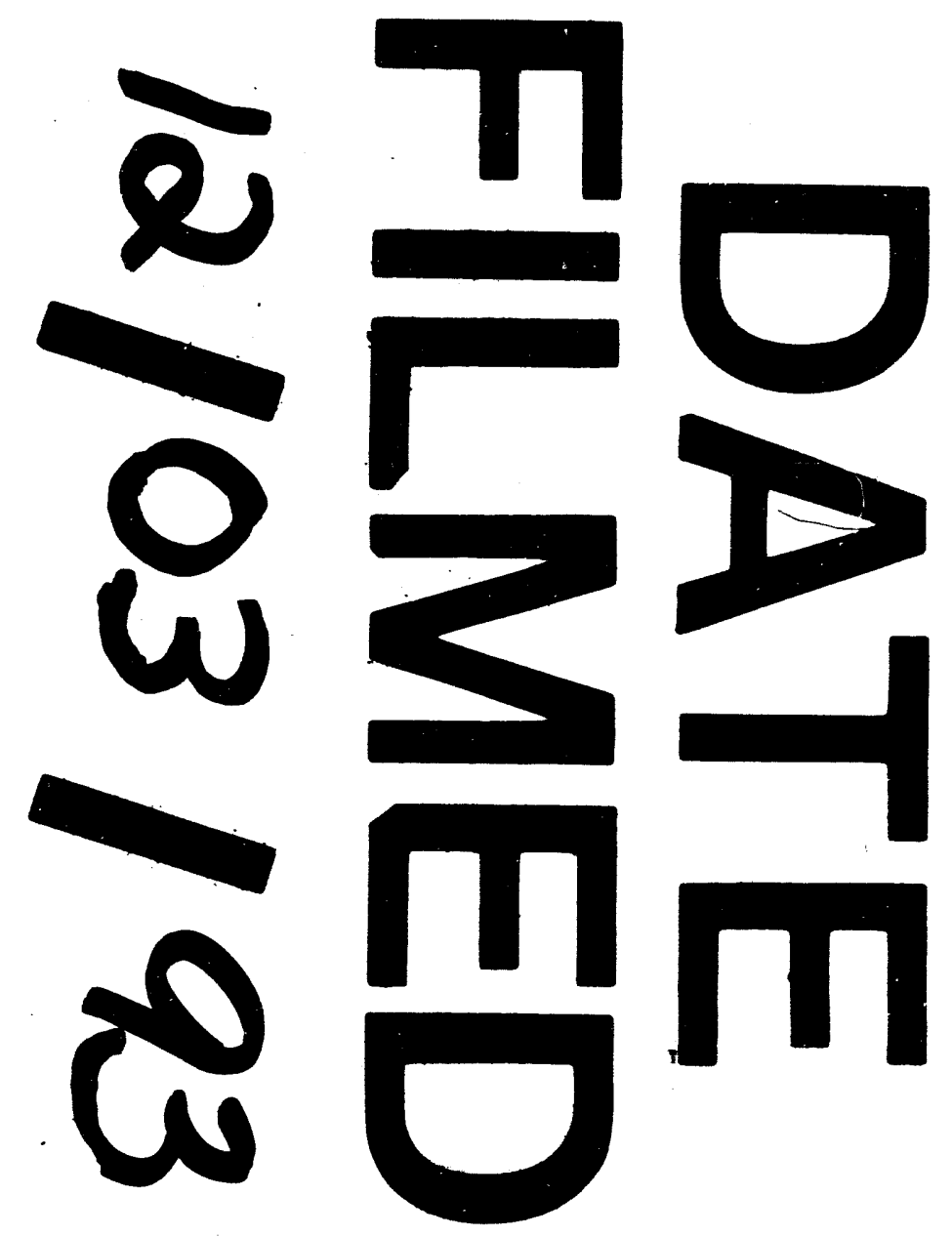




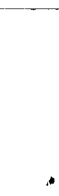

